\title{
Az a-melanocita stimuláló hormon gyulladáscsökkentő hatása biológiai gátrendszerek tenyészetes modelljein
}

\author{
Doktori (Ph.D.) értekezés
}

\section{Harazin András}

Témavezetők: Dr. Deli Mária, tudományos tanácsadó MTA Szegedi Biológiai Kutatóközpont, Biofizikai Intézet Dr. Tubak Vilmos, tudományos igazgató Creative Labor Kft.

\author{
Biológia Doktori Iskola \\ Természettudományi és Informatikai Kar \\ Szegedi Tudományegyetem
}

2018

Szeged 


\section{Tartalomjegyzék}

Publikációs lista:.............................................................................................................................. III

Rövidítések jegyzéke .................................................................................................................... IV

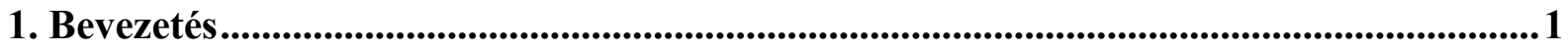

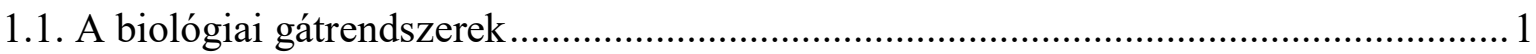

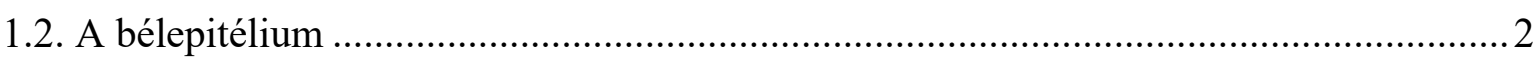

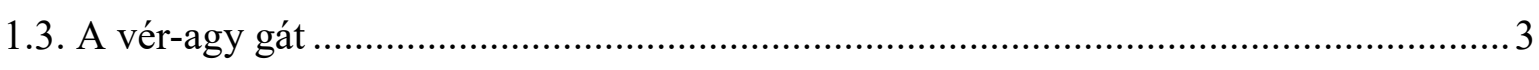

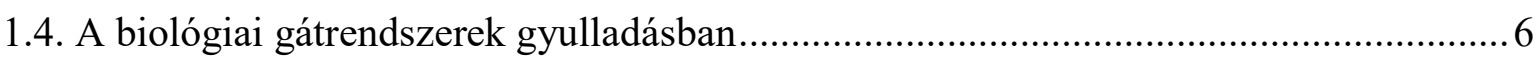

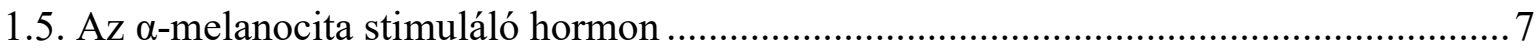

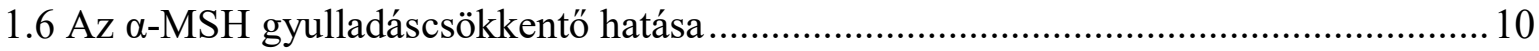

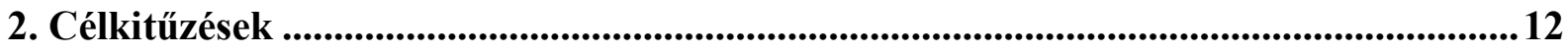

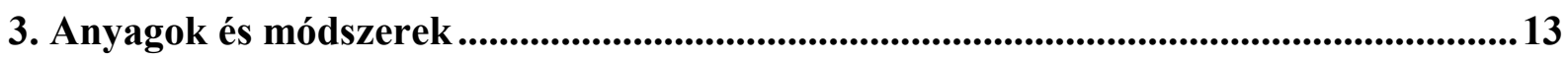

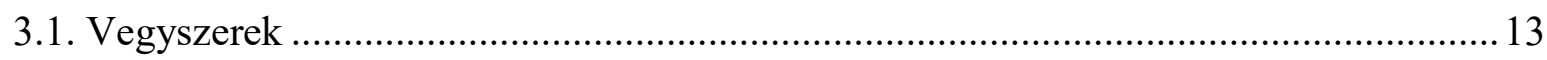

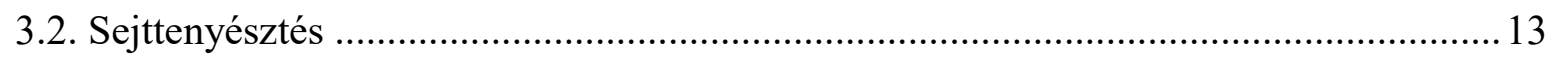

3.2.1. A humán Caco-2 bélepitél-sejtvonal tenyésztése .............................................. 13

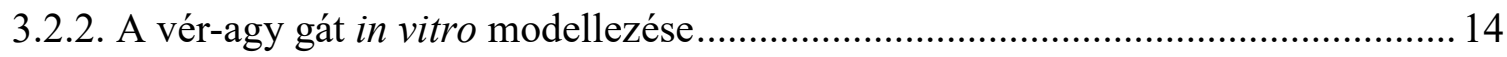

3.2.2.1. Agyi endotélsejtek tenyésztése ................................................................. 14

3.2.2.2. Agyi mikroér periciták tenyésztése …..................................................... 15

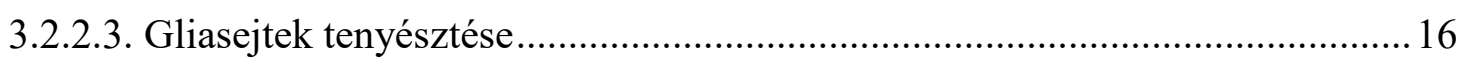

3.2.2.4. A vér-agy gát ko-kultúra modellje .......................................................... 16

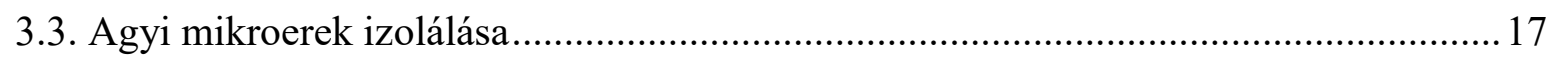

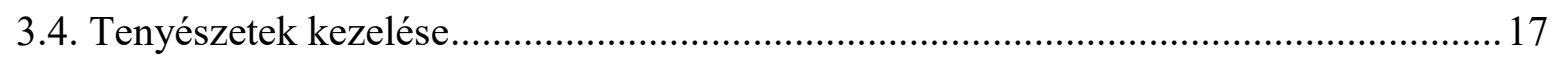

3.5. Reverz transzkripciót követő polimeráz láncreakció.............................................. 18

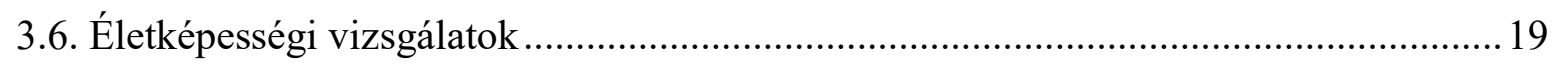

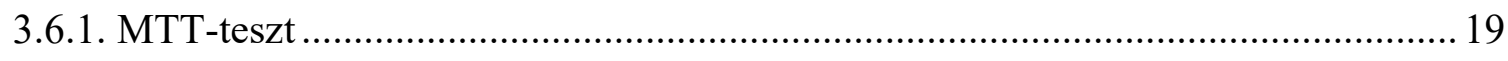

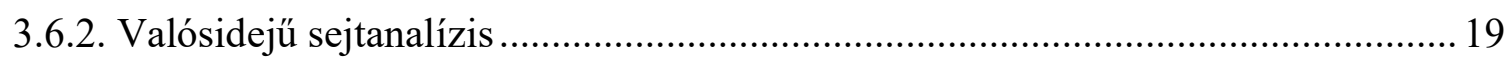

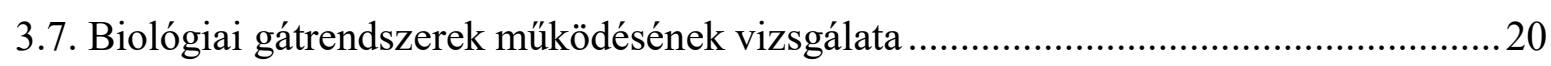

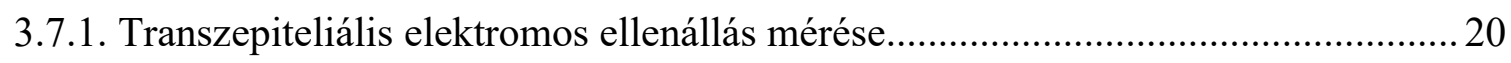

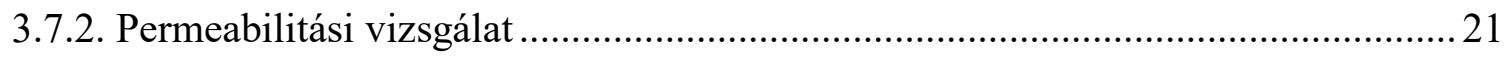

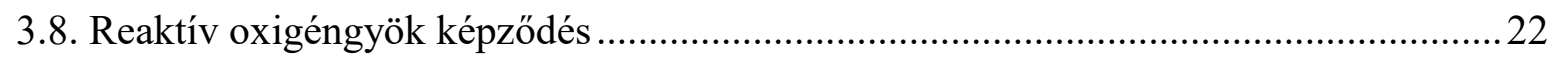

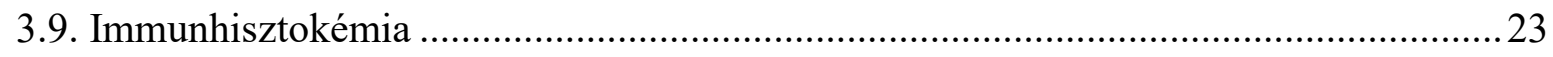

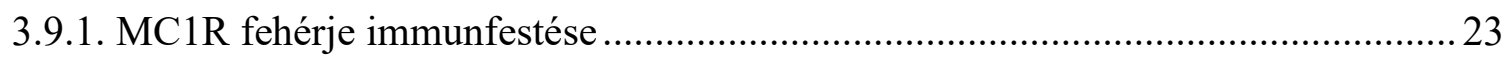

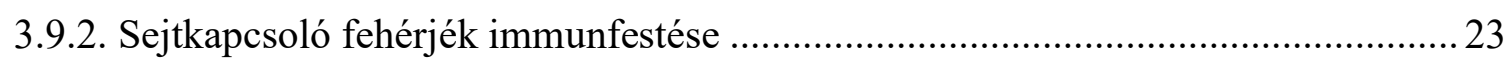

3.9.3. Az NF- $\kappa B$ transzkripciós faktor sejtmagba történő bejutásának vizsgálata ........... 24

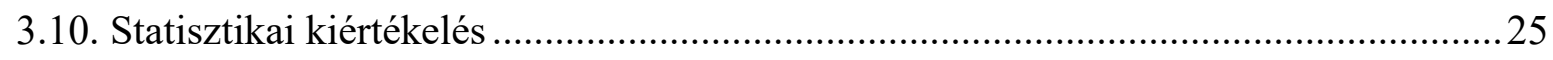

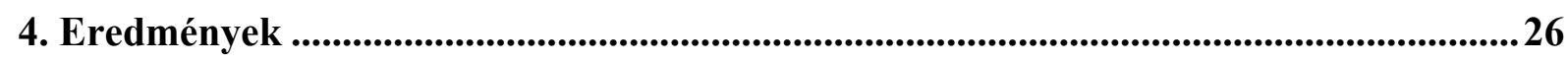

4.1. MC1R fehérje jelenléte bélepitél- és agyi endotélsejteken .....................................26 
4.2. Az $\alpha$-MSH hatása agyi endotélsejt-tenyészeteken

4.3. A citokinek és az $\alpha$-MSH hatása agyi endotélsejt-tenyészetek életképességére

4.4. A citokinek és az $\alpha-M S H$ hatása a biológiai gátrendszerek tenyészetes modelljeinek integritására

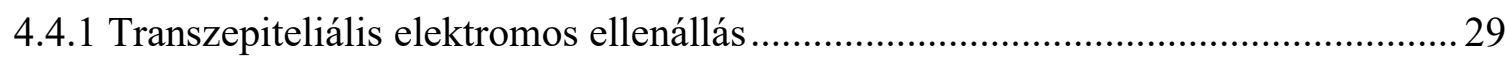

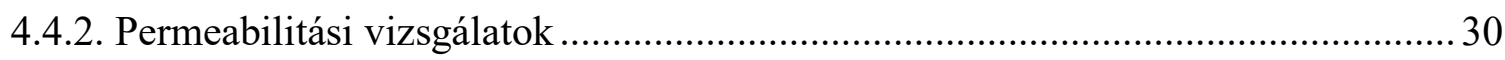

4.5. A citokinek és az $\alpha$-MSH hatása a reaktív oxigéngyökök termelődésére agyi endotélsejtekben

4.6. A citokinek és az $\alpha$-MSH hatása az epitél- és agyi endotélsejtek sejtkapcsoló fehérjéire

4.6.1. Klaudin-4 és ZO-1 immunhisztokémia Caco-2 sejteken...................................... 32

4.6.2. A klaudin-5 és $\beta$-katenin festődése patkány agyi endotélsejtekben ...................... 32

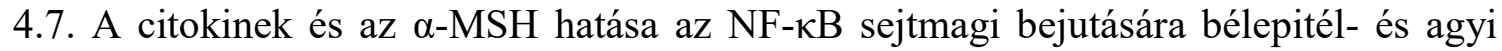
endotélsejtekben

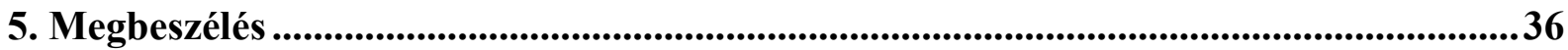

5.1. Az MC1R fehérje jelenléte a bélhám és a vér-agy gát tenyészetes modelljein ............. 36

5.2. Az $\alpha$-MSH peptid önálló hatása agyi endotélsejtekre .............................................. 36

5.3. Az $\alpha-M S H$ védőhatása citokinekkel kiváltott károsodással szemben .............................. 37

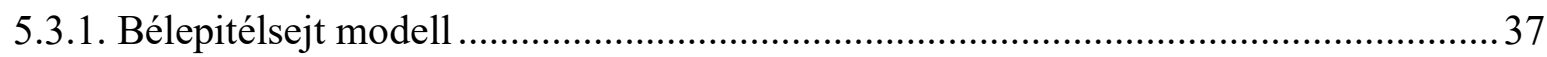

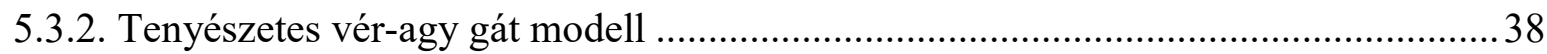

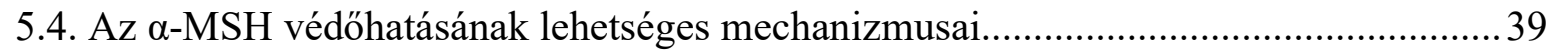

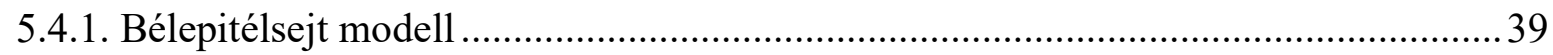

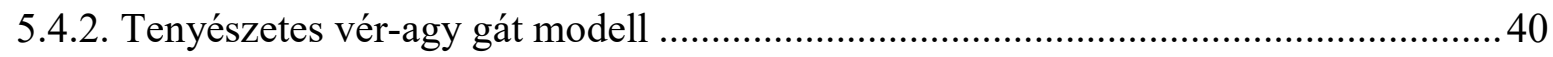

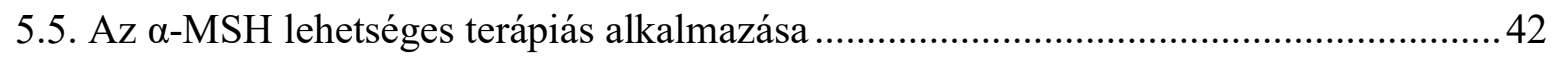

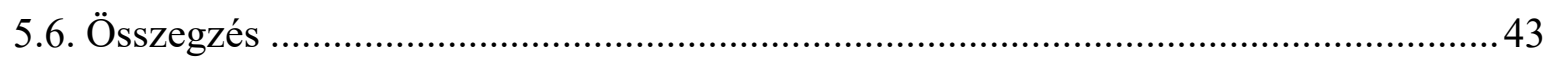

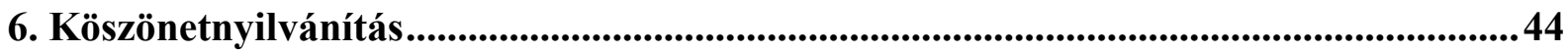

7. Irodalomjegyzék ............................................................................................................46

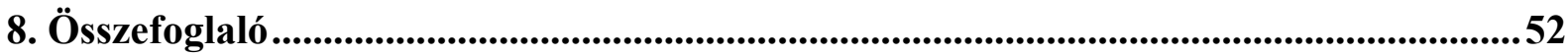

9. Summary ….....................................................................................................................................55

\section{Függelék}




\section{Publikációs lista:}

MTMT azonosító: 10052432

Kumulatív hatástényező (IF): 4,983

\section{A tézis tárgyához tartozó publikációk}

I. Váradi J, Harazin A, Fenyvesi F, Réti-Nagy K, Gogolák P, Vámosi G, Bácskay I, Fehér P, Ujhelyi Z, Vasvári G, Róka E, Haines D, Deli MA, Vecsernyés M.

Alpha-melanocyte stimulating hormone protects against cytokine-induced barrier damage in Caco-2 intestinal epithelial monolayers.

PLoS One. 12:e0170537 (2017)

IF: 2,806

II. Harazin A, Bocsik A, Barna L, Kincses A, Váradi J, Fenyvesi F, Tubak V, Deli MA, Vecsernyés M.

Protection of cultured brain endothelial cells from cytokine-induced damage by alpha-melanocyte stimulating hormone.

PeerJ, 6:e4774 (2018)

IF: 2,177

\section{A tézis tárgyához közvetlenül nem tartozó publikáció}

III. Lénárt N, Walter FR, Bocsik A, Sántha P, Tóth ME, Harazin A, Tóth AE, Vizler C, Török Z, Pilbat AM, Vígh L, Puskás LG, Sántha M, Deli MA.

Cultured cells of the blood-brain barrier from apolipoprotein B-100 transgenic mice: effects of oxidized low-density lipoprotein treatment.

Fluids and Barriers of the CNS. 12:17 (2015)

IF: - 


\section{Rövidítések jegyzéke}

ACTH - mellékvesekéreg serkentő hormon (adrenokortikotróp hormon)

$\alpha$-MSH - $\alpha$-melanocita stimuláló hormon

bp - bázispár

BSA - borjúszérum albumin

cAMP - ciklikus 3', 5'-adenozin-monofoszfát

CLS2 - 2-es típusú kollagenáz

$\mathrm{CO}_{2}-$ szén-dioxid

DMEM - Dulbecco módosította Eagle-médium

EBA - Evans-kék kötött albumin

ESAM - endoteliális sejtadhéziós molekula

FBS - fötális borjúszérum

FITC - fluoreszcein izotiocianát

IL-1 $\beta$ - interleukin- $1 \beta$

I $\mathrm{B}-\mathrm{NF}-\kappa \mathrm{B}$ transzkripciós faktort gátló fehérje

JAM - junkcionális adhéziós molekulák

$\mathrm{MCR}$ - melanokortin receptor

MTT - 3-(4,5-dimetiltiazol-2-il)-2,5-defenil tetrazólium-bromid

$\mathrm{NF}-\kappa \mathrm{B}$ - nukleáris faktor $\kappa \mathrm{B}$ fehérje

PBS - foszfát pufferoldat

PCR - polimeráz láncreakció

PECAM-1 - vérlemezke-endotélsejt adhéziós molekula

POMC - pro-opiomelanokortin

ROS - reaktív oxigéngyökök

S.E.M. - az átlag standard hibája

$\mathrm{SF}$ - nátrium-fluoreszcein

SLC - solute carrier tápanyagszállító fehérjecsalád

TEER - transzepiteliális elektromos ellenállás

$\mathrm{TJ}$ - szoros kapcsolat (tight junction)

TNF- $\alpha$ - tumor nekrózis faktor- $\alpha$

VE-kadherin - vaszkuláris endoteliális kadherin

ZO-1 - zonula occludens-1 fehérje 


\section{Bevezetés}

\subsection{A biológiai gátrendszerek}

A soksejtü szövetes szervezeteket különböző, hámszöveti sejtek alkotta gátrendszerek határolják. Az elsődleges határfelületek a külső barrierek, amelyek elválasztják a szervezet egészét a külvilágtól. Ilyen gátrendszernek tekinthetjük a legnagyobb érzékszervet, a bőrt, valamint a légutak és a bélcsatorna nyálkahártyáját (Deli, 2009; Krizbai és mtsai, 2015). Ezek a felületek megakadályozzák, hogy káros anyagok, kórokozók szabadon jussanak a szervezetbe, ugyanakkor kommunikációs felszínt is biztosítanak a külvilággal. Ezeken a határfelületeken átjutva az immunrendszer által veszélyesként felismert antigének helyi választ válthatnak ki, amely a keringési rendszer révén később szervezetszintű választ okozhatnak.

A szervezet másodlagos védelmi vonala az annak egészét behálózó és összekötő érpályarendszer és az immunológiai szempontból kitüntetett helyzetet élvező szervek közötti határfelületek, a vér-szöveti barrierek (Fromm, 2004). Ilyen gátrendszer található többek között a hímivarsejteket termelő herében, a fejlődő magzat ellátására szolgáló méhlepényben, valamint az idegrendszerben. Az idegi gátrendszerek közül kiemelt fontosságú a vér-agy gát, amelyet az agyi hajszálerek endotélsejtjei alkotnak (Neuwelt és mtsai, 2011). Ezek a felületek védelmet nyújtanak a vérben keringő lehetséges káros anyagokkal és kórokozókkal szemben, fontos szerepük van a szervek állandó belső egyensúlyának, homeosztázisának fenntartásában, és az immunsejtek átjutásának szabályozásában élettani és kórtani körülmények között.

A biológiai gátrendszerek anatómiai alapját a különleges felépítésű hámsejtek és belhámsejtek képezik, amelyek egymáshoz szorosan kapcsolódnak. A sejtek közötti rést, az úgynevezett paracelluláris utat sejtkapcsoló membránfehérjék zárják le. Az így kialakuló szoros kapcsolatok (tight junction, TJ) képezik az elsődleges, fizikai alapját ezeknek a gátrendszereknek (Cereijido és mtsai, 2008).

A biológiai gátrendszerek vizsgálatára számos jól beállított tenyészetes modell áll rendelkezésre. Habár a biológiai gátrendszerek megfelelő müködéséhez elengedhetetlen a szöveti mikrokörnyezet, a laborkörülmények között, in vitro tenyésztett epitél- és endotélsejtek kifejezik az élettani körülmények között megfigyelhető legfontosabb barriersajátosságokat, például a sejtkapcsoló és szállító fehérjéket. Munkánk során egy külső gát, a bélhám, és egy belső barrier, a vér-agy gát tenyészetes modelljét alkalmaztuk. 


\subsection{A bélepitélium}

A legnagyobb külső határfelületnek tekinthető gátrendszerünk a bélcsatorna nyálkahártyája a maga $200 \mathrm{~m}^{2}$ nagyságú felületével (Deli, 2009). A gasztrointesztinális gát a szimbionta baktériumokkal együtt segíti a táplálékfelvételt és az emésztést, az immunrendszer sejtjeivel együtt pedig védelmezi a szervezetet (König és mtsai, 2016). A szájüreget és a végbelet bélelő többrétegű laphám epitélium mellett a bélcsatorna nyálkahártyának nagy részét köbös alakú laphámsejtek alkotják, melyeket különböző sejtkapcsoló struktúrák füzik egymáshoz megakadályozva, hogy anyagok, bélbaktériumok, vagy kórokozók szabadon jussanak a szervezetbe (1. ábra).

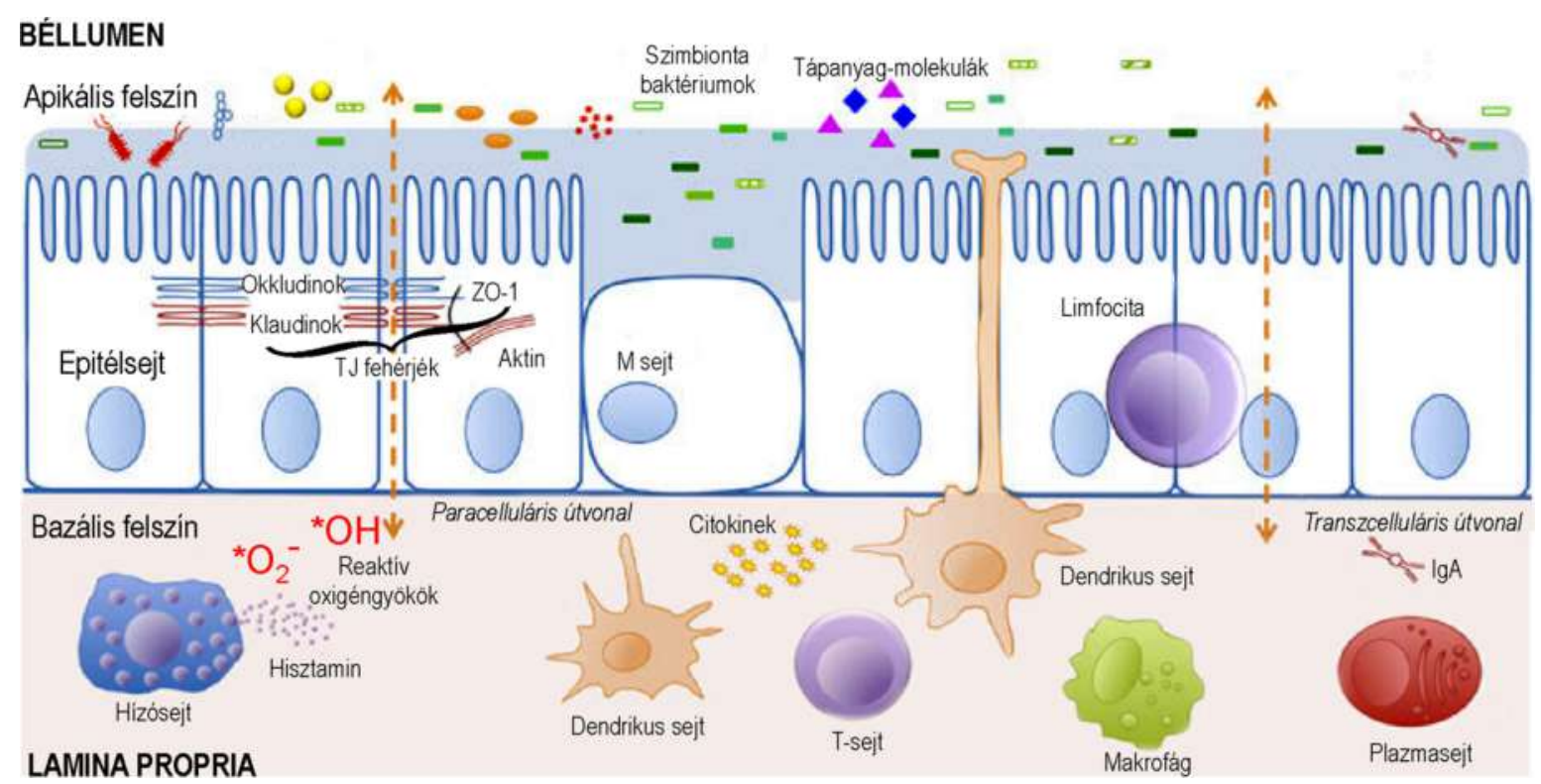

1. ábra. A bélepitélium szerkezetének és felépítésének sematikus rajza (König és mtsai, 2016 alapján).

A bélepitélium hámsejtjeit a TJ fehérjék elhelyezkedése alapján létrejövő polaritás jellemzi. A sejtek apikális, béllumen felé eső részének függeléke a vékonybélben fontos felszívódási felszínt biztosító kefeszegély, ahol a különböző lebontott tápanyagok felvételében szerepet játszó receptor- és transzportfehérjék találhatók. Az epitélsejtek bazális felszíne nagy számban fejez ki a bazális membránhoz kapcsolódó fehérjéket és a felvett tápanyag-molekulák keringésbe juttatásáért felelős efflux pumpákat és tápanyagszállító fehérjéket (König és mtsai, 2016). A sejteket egymáshoz füző szoros kapcsolatok és a sejt polaritásának megfelelő oldalon kifejezett fehérjék az anyagok egyirányú, szabályozott áramlását teszik lehetővé (Deli, 2009). A sejteken keresztül, 
transzcelluláris úton és passzív módon kerülnek a keringésbe a zsírban oldódó nagyobb molekulák, míg a vízben oldódó molekulák és tápanyagok aktívan, szállító fehérjék segítségével. A szervezet számára mérgező anyagokat efflux pumpák juttatják vissza a béllumenbe (Fromm, 2004).

Az epitélsejtek apikális felszínéhez legközelebb található a sejteket övszerüen körbeölelö és egymáshoz kapcsoló TJ struktúra (1. ábra), amelyet olyan integráns TJ membránfehérjék alkotnak, mint az okkludin, tricellulin, klaudin-2, -3, -4, -7, -8, -12 és 15, amelyek a zonula occludens (pl. ZO-1) linker fehérjéken keresztül kapcsolódnak az aktinból felépülő sejtvázhoz (Deli, 2009; Groschwitz és Hogan, 2009). A szoros kapcsolatok fehérje-összetétele a bélszakasztól függően eltéréseket mutat, de mindenhol elsődlegesen gátolja az anyagok szabad átjutását a gátrendszeren. A TJ fehérjék másik nagyobb csoportja a junkcionális adhéziós molekulák (JAMok), melyek az okkludinnal és a klaudinokkal együtt a sejtmembránban övszerüen elhelyezkedve megakadályozzák a membránfehérjék szabad diffúzióját, kialakítva ezáltal a sejtek polaritását. A szoros kapcsolatoktól bazális irányban helyezkednek el a kalciumkötésre képes kadherin és az immunglobulinszerű nektin fehérjecsaládok egyes képviselöiből felépülő adherens kapcsolatok vagy övdezmoszómák, melyek az aktin sejtvázhoz kapcsolódva szintén hozzájárulnak az epitélsejtek egymáshoz kapcsolódásához (Groschwitz és Hogan, 2009). A bélhámsejtek bazális felszínéhez közel találhatók a foltdezmoszómák, melyek az extracelluláris mátrix fehérjéihez kapcsolják a sejteket.

A béltraktusban élő szimbionta bélbaktériumok nemcsak elősegítik az emésztést és az élő szervezet számára fontos vitaminokat termelnek, hanem meghatározó jelentőségűek az immunrendszer, a bélepitélium és más szöveti barrierek müködése szempontjából is (Al-Asmakh és Hedin, 2015). Ugyanakkor a gátrendszer sérülése esetén a szervezetbe kerülve a baktériumok immunválaszt, helyi gyulladást válthatnak ki. A bélbaktériumok mellett az immunrendszer sejtjei is szerepet játszanak az intesztinális gát megfelelő müködésében. Az immunsejtek által termelt citokinek hatással vannak a bélepitélsejtek fehérje-kifejeződésére, és a limfociták által termelt reaktív oxigéngyökök (ROS) és a hízósejtek hisztaminja mellett a barrier megnyílását okozhatják (König és mtsai, 2016).

\subsection{A vér-agy gát}

A központi idegrendszer ionos homeosztázisának és az idegsejtek megfelelő tápanyag-ellátottságának fenntartásában elsődleges szerepe van a vér-agy gátnak (Abbott és mtsai, 2006). A dinamikus határfelület anatómiai alapját az agyi hajszálerek falát 
felépítő belhámsejtek vagy endotélsejtek képezik, amelyek az őket körülvevő sejtekkel együttmüködve látják el a központi idegrendszer védelmét és anyagcseréjét (2. ábra). A felnőtt emberi agyban található hajszálerek hossza megközelítőleg $650 \mathrm{~km}$, felszíne mintegy 15-20 m² (Deli, 2009). Az agyi endotélsejtek közös bazális membránban helyezkednek el az összehúzódásra képes, ezáltal az érátmérőt szabályozó pericitákkal (Abbott és mtsai, 2010; Attwell és mtsai, 2016). Míg a hajszálereket teljes hosszukban beborítják az agyban található asztrogliasejtek végtalpai, amelyek révén intenzív kölcsönhatás alakul ki a különbözö, idegrendszert felépítő sejttípusok között. A vér-agy gátat alkotó három sejttípus az erek körüli mikroglia és a mikroereket beidegző idegsejtekkel, valamint a vérben keringő sejtekkel együtt alkotja a neurovaszkuláris egységet, amelynek összehangolt müködése meghatározó és kulcsfontosságú a központi idegrendszer fejlődése és müködése szempontjából (Neuwelt és mtsai, 2011).

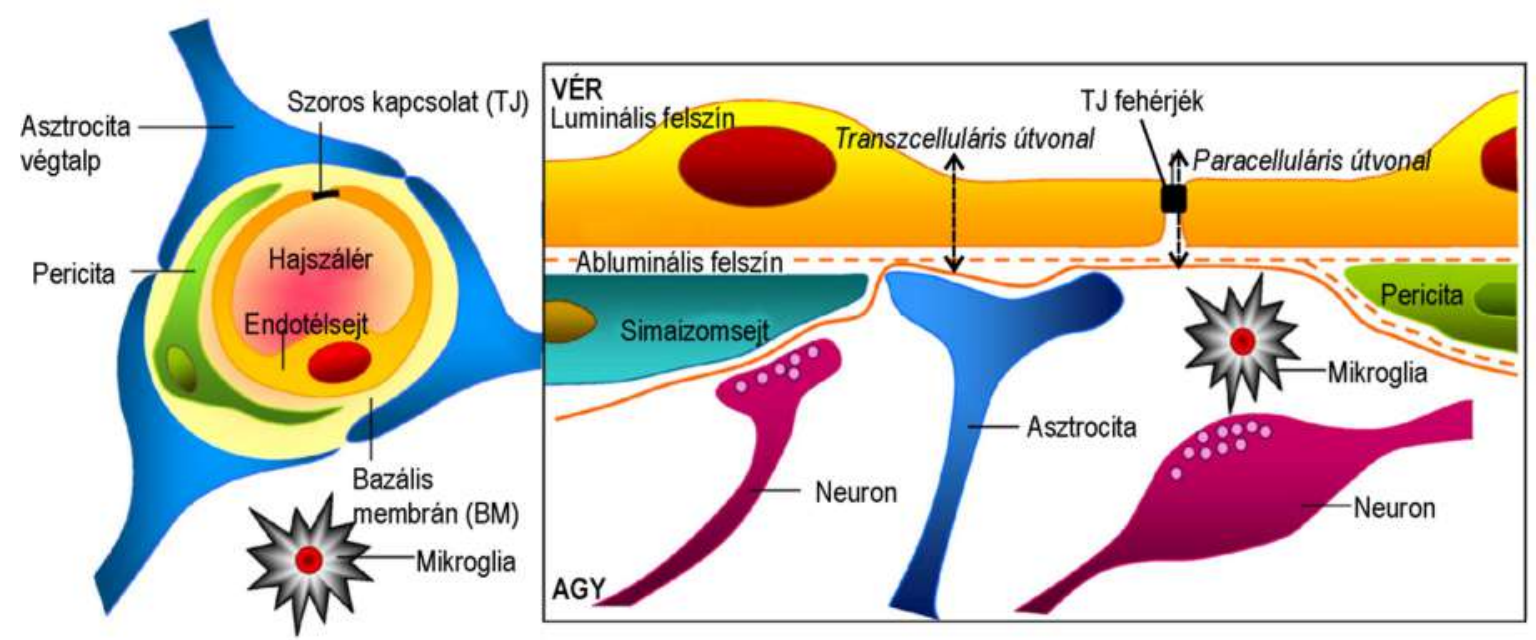

2. ábra. A vér-agy gát szerkezetének és felépítésének sematikus rajza (Abbott és mtsai, 2010 alapján).

Az agyi ionos egyensúly megteremtésén túl a vér-agy gát szerepet játszik az agy tápanyagokkal való ellátásában, a káros anyagok és bomlástermékek eltávolításában, valamint a periféria és az idegrendszer közötti információátadásban (Abbott és mtsai, 2010). Mindezeket elsősorban az agyi endotélsejtek sajátos felépítése teszi lehetővé. A lapos, elnyúlt sejtekre a bélepitélsejtekhez hasonlóan polaritás jellemző. A perifériás szervek endotélsejtjeivel szemben nincs fenesztráció, és kevés a pinocitotikus vezikula. Az agyi endotélsejtek vér felőli, luminális felszínén vastag glikokalix található, emellett nagy számban fejeződnek ki efflux pumpafehérjék, melyek megakadályozzák növényi vagy mikrobiális vegyületek, egyéb xenobiotikumok idegrendszerbe való bejutását, míg a 
metabolikus enzimek a bioaktív vegyületekkel szemben biztosítanak védelmet (Banks, 2016). A vér-agy gáton található tápanyagszállító fehérjék (SLC transzporter fehérjecsalád) nélkülözhetetlenek a cukrok, aminosavak, lipidek, vitaminok idegrendszerbe juttatása szempontjából (Campos-Bedolla és mtsai, 2014). Az SLC transzporterek az agyi endotélsejtek luminális felszínén nagy számban és mennyiségben fejeződnek ki, míg a sejtek agy felőli, abluminális felszínére vékonyabb glikokalix és eltérő tápanyagszállító fehérje-összetétel jellemző (Abbott és mtsai, 2010). A zsírban oldódó anyagok a vér-agy gáton át passzív diffúzióval kerülnek be a központi idegrendszerbe. Mivel az agyi endotélsejtek közötti paracelluláris útvonalat a szoros kapcsolatok lezárják, a nagyobb lipofil molekulák, valamint a vízben oldódó tápanyagok, peptidek és fehérjék SLC fehérjék segítségével, valamint adszorptív- és receptor-mediált transzcelluláris transzporttal jutnak be az agyszövetbe (Abbott és mtsai, 2006).

A vér-agy gátnál a többi biológiai gátrendszerhez hasonlóan a sejtek körül övszerüen körbefutó TJ struktúrák kiemelten fontosak. Az agyi endotélsejtek szoros kapcsolatainak felépítésében is számos transzmembrán TJ fehérje vesz részt. Egy részük, mint az okkludin, a tricellulin, a JAM az epitélsejtekben is megtalálható (1. táblázat). A bélepitélsejtekkel szemben a vér-agy gát domináns TJ fehérjéje a klaudin-5, valamint az endoteliális sejtadhéziós molekula (ESAM) (Deli, 2009). Az endotélsejtekre specifikus adherens junkció fehérje a VE-kadherin és a vérlemezke-endotélsejt adhéziós molekula (PECAM-1), amelyek a nektinekkel együtt az intracelluláris kateninek révén kapcsolódnak a citoszkeletonhoz és stabilizálják a sejtek közötti kapcsolatokat (1. táblázat).

1. táblázat. Az intesztinális és a vér-agy gát felépítésének összehasonlítása (Deli, 2009 alapján). Félkövérrel szedve a gátrendszerek közötti fontosabb különbségek.

\begin{tabular}{|c|c|c|}
\hline & Bélepitélium & Vér-agy gát endotélium \\
\hline Gátrendszer & külső & belső \\
\hline $\begin{array}{l}\text { Apikális/luminális } \\
\text { függelék }\end{array}$ & mikrovillus, glikokalix & glikokalix \\
\hline \multirow{3}{*}{$\begin{array}{l}\text { Szoros kapcsolatot (TJ) } \\
\text { kialakító fehérjék }\end{array}$} & okkludin, tricellulin & okkludin, tricellulin \\
\hline & klaudin-1, -2, -3, -4, -7, -15 & klaudin- $1,-3,-5,-15$ \\
\hline & JAM-A, -B, -C, CAR & JAM-A, -B, -C, CAR, ESAM \\
\hline \multirow{2}{*}{$\begin{array}{l}\text { Adherens kapcsolatot } \\
\text { (AJ) kialakító fehérjék }\end{array}$} & E-kadherin & VE-kadherin \\
\hline & nektinek & nektinek, PECAM-1 \\
\hline
\end{tabular}


A TJ segítségével szorosan egymáshoz kapcsolódó agyi endotélsejtek igen magas ellenállást mutatnak ionokra: kísérleti állatok agyi mikroereiben mintegy $2000 \Omega$ elektromos ellenállás mérhető az endotélsejtréteg két oldala között (Pardridge, 2002).

A vér-agy gát és az idegrendszer müködésének fontos szabályozói még az immunsejtek, melyek aktivált állapotban képesek kitapadni az endotélsejtek felszínére és a TJ fehérjék között, illetve a sejteken át (diapedezis) az agyba jutni (Engelhardt és mtsai, 2017). A központi idegrendszerben az elsődleges immunológiai feladatot a mikrogliasejtek látják el, melyek aktiválódása alapvetően képes megváltoztatni a vér-agy gát müködését.

\subsection{A biológiai gátrendszerek gyulladásban}

A dinamikus határfelületek biológiai funkciójuk betöltéséhez folyamatos kölcsönhatásban állnak a külső és a belső terekkel, azaz az apikális vagy luminális és bazális vagy abluminális oldalakkal. A gátrendszerek homeosztázist fenntartó és védőfunkciói, és azok vizsgálata nemcsak élettani körülmények között fontos, hanem betegségekben is. A legtöbb kórtani állapotban megfigyelhetőek a helyi, vagy akár szisztémás gyulladásos folyamatok, amelyek alapvetően befolyásolják a barrierek müködését. Emellett a bél- és agyi barrierek müködésének romlása, illetve károsodása is hozzájárul a gyulladásos folyamatok és betegségek kialakulásához (Lee, 2015; Erickson és Banks, 2018).

A bélrendszert bélelő epitélium sérülése figyelhető meg gyulladásos bélbetegségekben és a csontvelő- vagy őssejt átültetés következtében fellépő graft versus host betegségben is (Nalle és Turner, 2015). A megbetegedések során megemelkedik a gátrendszer áteresztőképessége és a tünetek súlyosságával arányosan fokozódik a bélepitélium funkcióvesztése, amelynek alapja az epitélsejtek és az azokat összekapcsoló TJ fehérjék közvetlen károsodása (Lee, 2015). További közös jellemzője a Crohnbetegségnek, a fekélyes vastagbélgyulladásnak (colitis ulcerosa) és a graft versus host betegségnek a gyulladáskeltő citokinek, a tumor nekrózis faktor- $\alpha$ (TNF- $\alpha$ ) és az interleukin-1 $\beta$ (IL-1 $\beta$ ) magas szintje a megbetegedés súlyosságától függően (Nalle és Turner, 2015). A gyulladáskeltő citokinek bélepitéliumra kifejtett károsító hatását állatkísérletes és tenyészeten végzett kutatások is bizonyították. Az IL-1 $\beta$ gátmegnyitó hatását a bélhám modellezésére széles körben alkalmazott humán Caco-2 epitélsejtvonalon (Al-Sadi és mtsai, 2010), és egérmodellen is kimutatták (Al-Sadi és mtsai, 2012). Hasonló barriert károsító és gyulladást kiváltó választ igazoltak bélepitélsejteken TNF- $\alpha$, illetve TNF- $\alpha$ és IL-1 $\beta$ együttes adása után (Van De Walle és mtsai, 2010). 
A szisztémás gyulladások során felszabaduló citokinek a keringés útján a belső gátrendszerek, így a központi idegrendszert védelmező vér-agy gát müködésére is hatással vannak (Erickson és Banks, 2018). Így például az akut hasnyálmirigy-gyulladás kísérletes modelljében a gyulladáskeltő citokinek, köztük a TNF- $\alpha$ megemelkedett szintjét mutatták ki a vérben a vér-agy gát áteresztőképességének fokozódásával párhuzamosan (Farkas és mtsai, 1998). Ez az eredmény azzal a klinikai megfigyeléssel együtt, hogy a hasnyálmirigy-gyulladás súlyos formájától szenvedő betegek mintegy ötödénél tájékozódásbeli zavarok, agyi bevérzések figyelhetők meg, felveti a vér-agy gát szerepét a központi idegrendszeri károsodás kialakulásában a pankreatikus enkefalopátia kórképben (Ding és mtsai, 2004).

A gyulladáskeltő citokinek közül a TNF- $\alpha$ és az IL-1 $\beta$ a két leginkább tanulmányozott molekula, melyek részt vesznek központi idegrendszeri gyulladásos folyamatokban (Liebner és mtsai, 2018), illetve a szisztémás gyulladások következtében fellépő neuroinflammációban (Hoogland és mtsai, 2015). A TNF- $\alpha$ közvetlenül fokozza a vér-agy gát permeabilitását állatkísérletekben (Megyeri és mtsai, 1992; Ábrahám és mtsai, 1996), és ez a hatás tenyészetes modelleken is megfigyelhető (Deli és mtsai, 1995). Ugyanígy kimutatható az IL-1 $\beta$ barriermegnyitó hatása is in vitro vér-agy gát modellen (Deli és mtsai, 2005). Mivel a TNF- $\alpha$ és a IL-1 $\beta$ játszik központi szerepet mind a szisztémás, mind az idegrendszeri gyulladásokban, kísérleteinkhez ezt a két citokint választottuk.

\subsection{Az $\alpha$-melanocita stimuláló hormon}

Az $\alpha$-melanocita stimuláló hormon ( $\alpha$-MSH) egy endogén peptid, ami a melanokortinok családjába tartozik, és a pro-opiomelanokortin (POMC) prohormonból képződik (3. ábra). A POMC génről átíródó fehérjéből enzimatikus hasítások révén keletkezik az agyalapi mirigy mellékvesekéreg serkentő hormonja (ACTH: adrenokortikotróp hormon), melyből újabb enzimatikus hasításokat követően képződik a 13 aminosavból felépülő $\alpha$-MSH (2. táblázat). Ugyanígy a POMC fehérjéből keletkezik hasonló enzimmüködéseknek köszönhetően a 22 aminosavból álló $\beta$-MSH, valamint a három izoformával is rendelkező $\gamma$-MSH. Mindhárom melanocita stimuláló hormonban van egy közös szekvencia (His-Phe-Arg-Trp), amely fontos szerepet játszik a hormoncsalád leginkább ismert feladatában, a bőr pigmentsejtjeiben történő melanintermelés beindításában (2. táblázat; Brzoska és mtsai, 2008). 


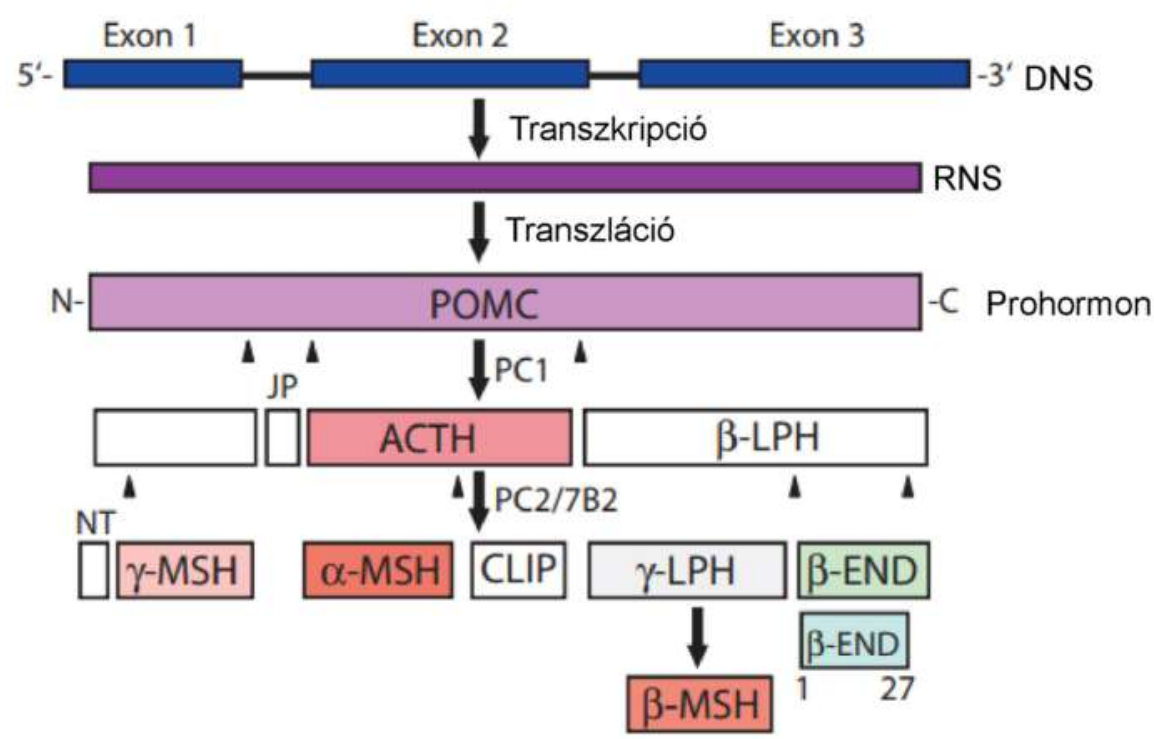

3. ábra. A POMC prohormon és a melanokortinok bioszintézise (Brzoska és mtsai, 2008). ACTH: adrenokortikotropin, $\alpha$-MSH: $\alpha$-melanocita stimuláló hormon, $\beta$-END: $\beta$-endorfin, $\beta$-LPH: $\beta$ lipotropin, $\beta$-MSH: $\beta$-melanocita stimuláló hormon, CLIP: kortikotropinszerủ közbülső peptid, $\gamma$ LPH: $\gamma$-lipotropin, $\gamma$-MSH: $\gamma$-melanocita stimuláló hormon, JP: kapcsolódó peptid, NT: $\mathrm{N}$ terminális peptid, PC1: prohormon konvertáz-1, PC2: prohormon konvertáz-2, POMC: proopiomelanokortin.

A $\alpha$-MSH neurohormon a festékanyagtermelés szabályozásán keresztül meghatározza különböző gerinces fajok bőr- illetve szőrszíneit (Hruby és mtsai, 1987). A peptid ugyanakkor szerepet játszik az energiaháztartás szabályozásában, hatással van a szexuális viselkedésre és széles körben vizsgált a hormon szerepe a melanómasejtek müködésében és a tumorképződés folyamatában (3. táblázat; Brzoska és mtsai, 2008). Habár a hormon elsődleges képződési helye az agyalapi mirigy elülső lebenye, egyre több tanulmány írja le, hogy számos perifériás szövetben, például a bőrben is termelödik az oligopeptid (Brzoska és mtsai, 2008).

2. táblázat. Az $\alpha$-MSH peptid jellemzői (Brzoska és mtsai, 2008; Schiöth és mtsai, 1998 alapján).

\begin{tabular}{|l|c|c|}
\hline \multicolumn{2}{|c|}{ Az $\boldsymbol{\alpha}$-MSH peptid jellemzői } \\
\hline Aminosavszekvencia & $\begin{array}{c}1 \\
\text { Ac }- \text { Ser }- \text { Tyr }- \text { Ser }- \text { Met - Glu }\end{array}$ His - Phe - Arg - Trp & Gly - Lys - Pro - Val - $\mathrm{NH}_{2}$ \\
\hline Kötődési affinitás & MC1R $>$ MC3R $>$ MC4R $>>$ MC5R \\
\hline
\end{tabular}

A melanokortin család molekulái evolúciósan konzervált molekulák, melyek a szöveti sérülések és a bakteriális fertőzések elleni védelemben játszanak szerepet már a korai gerinces csoportokban is (Catania, 2008). 
A melanokortinok saját hormonreceptorokhoz, a melanokortin receptorokhoz (MCR) kapcsolódva fejtik ki biológiai aktivitásukat. A receptorcsalád tagjai hét transzmembrándoménnel rendelkeznek és G-fehérje kapcsoltak: az adenilát-cikláz segítségével ciklikus 3',5'-adenozin monofoszfát (cAMP) másodlagos hírvivő molekulán keresztül indul be a jelátviteli útjuk (Catania, 2008).

Az MCR fehérjecsalád öt tagja különböző affinitással képes kötni a melanokortin peptideket (Brzoska és mtsai, 2008). Az MC2R fehérje kizárólag az ACTH molekulával lép kölcsönhatásba, így elsősorban a mellékvesekéregben a szteroid-termelődésért felelős, de leírták már zsírszövetben, a hasnyálmirigy $\beta$-sejtjeiben, illetve keratinocitákban is. Az $\alpha$-MSH hatásának közvetítéséért elsősorban a szervezetben számos szövettípusban kifejeződő MC1R fehérje felelős (3. táblázat).

3. táblázat. Az MCR receptorok jellemzöi (Brzoska és mtsai, 2008 és Lasaga és mtsai, 2008 alapján). Félkövérrel jelölve a disszertációban vizsgált gátrendszerek és gyulladásos folyamatok.

\begin{tabular}{|c|c|c|c|c|}
\hline Receptor & Kötődési affinitás & $\begin{array}{c}\text { Szöveti } \\
\text { kifejeződés }\end{array}$ & $\begin{array}{l}\text { Sejttenyészetes } \\
\text { kifejeződés }\end{array}$ & $\begin{array}{l}\text { Élettani } \\
\text { funkció }\end{array}$ \\
\hline MC1R & $\alpha-\mathrm{MSH}=\mathrm{ACTH}=\beta-\mathrm{MSH}>>\gamma-\mathrm{MSH}$ & $\begin{array}{l}\text { bőr, agy, } \\
\text { bél, here, } \\
\text { méhlepény, } \\
\text { tüdő, máj }\end{array}$ & $\begin{array}{l}\text { melanocita, } \\
\text { endotélsejt, } \\
\text { asztrocita, bél- } \\
\text { epitélium, } \\
\text { immunsejtek }\end{array}$ & $\begin{array}{l}\text { pigment- } \\
\text { termelés, } \\
\text { gyulladás }\end{array}$ \\
\hline MC2R & $\mathrm{ACTH}$ & $\begin{array}{l}\text { mellékvese, } \\
\text { here, bőr }\end{array}$ & $\begin{array}{l}\text { zsírsejt, } \\
\text { keratinocita }\end{array}$ & $\begin{array}{l}\text { szteroid- } \\
\text { szintézis }\end{array}$ \\
\hline MC3R & $\gamma-\mathrm{MSH}=\mathrm{ACTH}=\beta-\mathrm{MSH} \geq \alpha-\mathrm{MSH}$ & $\begin{array}{l}\text { agy, szív, } \\
\text { vázizom }\end{array}$ & $\begin{array}{l}\text { bélepitélium, } \\
\text { immunsejtek }\end{array}$ & $\begin{array}{l}\text { energia- } \\
\text { háztartás, } \\
\text { gyulladás }\end{array}$ \\
\hline MC4R & $\alpha-\mathrm{MSH}=\mathrm{ACTH}=\beta-\mathrm{MSH}>>\gamma-\mathrm{MSH}$ & $\begin{array}{l}\text { agy, bőr, } \\
\text { vázizom }\end{array}$ & dendritikus sejt & $\begin{array}{l}\text { energia- } \\
\text { háztartás, } \\
\text { erekció, } \\
\text { gyulladás }\end{array}$ \\
\hline MC5R & $\alpha-\mathrm{MSH} \geq \beta-\mathrm{MSH}=\mathrm{ACTH}>\gamma-\mathrm{MSH}$ & $\begin{array}{l}\text { vázizom, } \\
\text { agy, bör, } \\
\text { mirigysejt, } \\
\text { tüdő, szív }\end{array}$ & $\begin{array}{l}\text { zsírsejt, mirigy- } \\
\text { sejtek, bél- } \\
\text { epitélium }\end{array}$ & $\begin{array}{l}\text { mirigy- } \\
\text { müködés }\end{array}$ \\
\hline
\end{tabular}

Az MC1R receptor megtalálható a bőrben lévő pigmentsejteken és keratinocitákon, az erek belhámsejtjein, a bélepitéliumon, az agyi mikrogliákon és asztrocitákon, valamint az immunrendszer sejtjein és a harántcsíkolt izomszövetben is (Brzoska és mtsai, 2008; Lasaga és mtsai, 2008). Az MC3R molekula elsősorban a $\gamma$-MSH peptid kötéséért felelős 
és szintén számos szövetben megtalálható, így a hipotalamuszban, a bélcsatorna hámsejtjeiben és a limfocitákban. A receptor elsősorban az energiaháztartás és a táplálékbevitel szabályozásáért felelős (3. táblázat). Az MC4R a központi idegrendszerben az egyik leggyakoribb melanokortin receptortípus; kifejeződik az agykéreg, a talamusz, a hipotalamusz, az agytörzs és a gerincvelő idegsejtjeiben. A receptor az energiaháztartás, a vérnyomás és a merevedés szabályozásában játszik szerepet. Az MC5R molekula a vázizomban, az agyban, a külső elválasztású mirigysejtekben, a bélepitéliumban és számos immunsejtben található. Szerepe elsősorban a faggyúmirigy, a könnymirigy, az egyes emlősöknél a szem alatt megfigyelhető Harder-mirigy és a fityma alatti mirigyek müködésében fontos.

A receptorok szisztémás hatásait vizsgálva megállapítható, hogy az MC3R és az MC4R fehérjék elsősorban a testsúly szabályozásában fontosak, az MC2R a glükokortikoid hormonok termelődésében, míg az MC5R szervezetszintű hatásai tisztázatlanok. Az MC1R fehérje a pigmentsejtek serkentésén túl elsősorban a gyulladásos folyamatokban betöltött szerepe miatt fontos kutatási célpont (Lasaga és mtsai, 2008).

\subsection{Az $\alpha$-MSH gyulladáscsökkentő hatása}

Az $\alpha$-MSH allergiás és gyulladásos megbetegedésekben gyakorolt protektív hatása kiterjedt kutatások tárgyát képezi (4. ábra). A bőr, a tüdő, a szem, az ízületek, az intesztinális rendszer és az agy gyulladásos megbetegedéseinek állatmodelljeiben már leírták a peptidhormon lázcsillapító, túlélést elősegítő, és a gyulladásos citokinek szérumszintjét csökkentő hatását (Brzoska és mtsai, 2008). Ezekben a gyulladásos folyamatokban központi szerepet játszik az NF-kB transzkripciós faktor aktiválódása.

Az NF-кB fehérje élettani körülmények között a citoplazmában található, ahol az IאB gátlófehérjéhez kötődik (Catania, 2008). Különböző hatásokra, mint a citokinek, baktériumok által termelt anyagok és a vírusok, a gátlófehérje foszforilálódik és a proteoszómában lebomlik. Ezáltal az NF-אB fehérje mindkét alegysége (p50 és p65) képes bejutni a sejtmagba, és főként a gyulladásos folyamatokban szerepet játszó fehérjék génjeinek promóterjeihez kötődve fokozza a gyulladáskeltő fehérjék kifejeződését, és elösegíti a gyulladás folyamatát.

Az $\alpha$-MSH peptid receptoraihoz kötődve képes megemelni a cAMP szintjét a sejtben, ami a proteinkináz-A fehérjét aktiválva megvédi az IкB gátlófehérjéjét a foszforilálódástól. Az NF-кB fehérje ezáltal nem képes a sejtmagba jutni és elősegíteni a gyulladáskeltő citokinek kifejeződését (Manna és Aggarwal, 1998). 


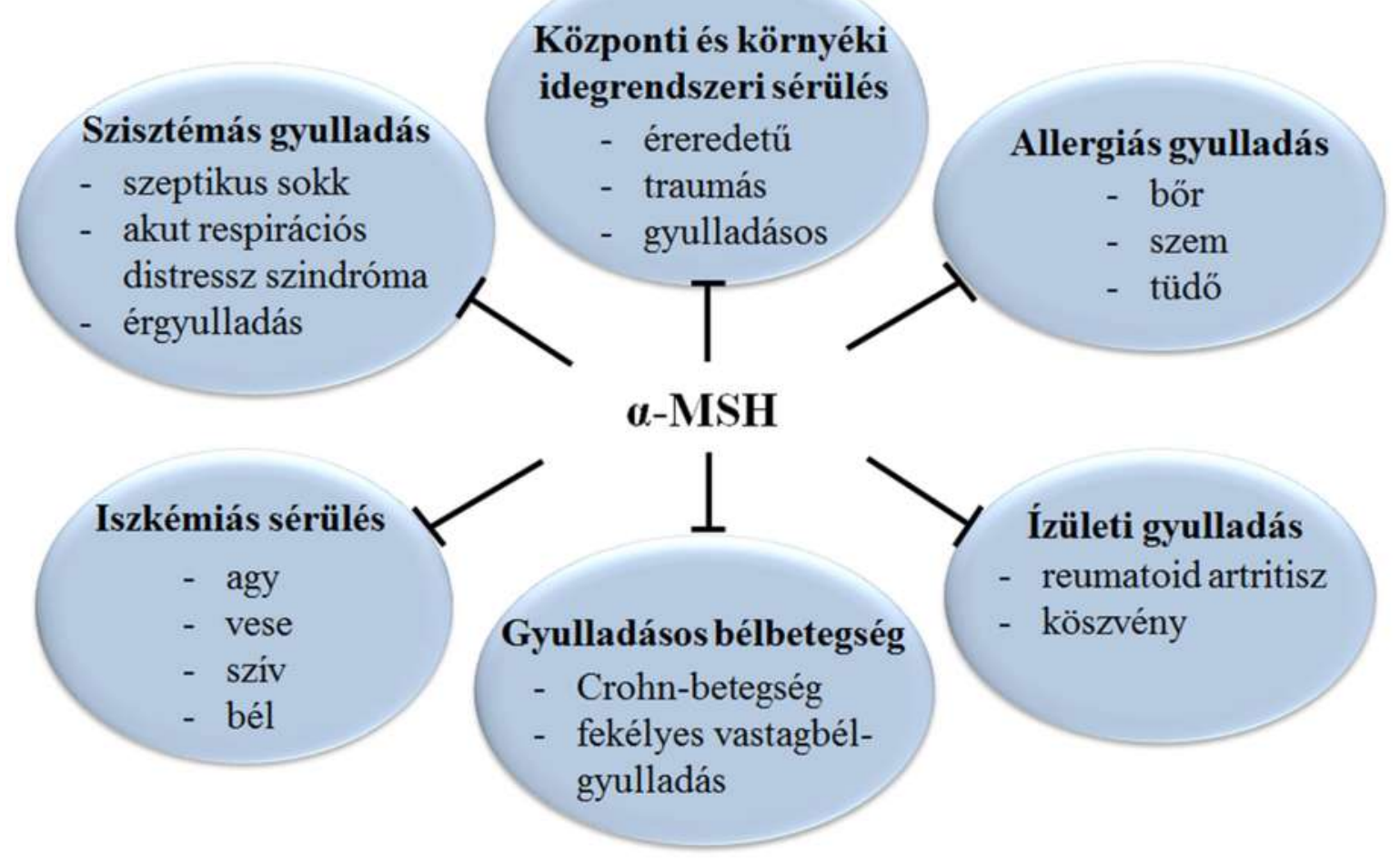

4. ábra. A melanokortinok gyulladáscsökkentő hatásai (Catania és mtsai, 2010 alapján).

Az $\alpha$-MSH bélrendszert védő hatását (4. ábra) bizonyítja, hogy az akut és krónikus vastagbélgyulladás patkánymodelljén is mérsékelte az állatok súlyvesztését, a vérzést és a TNF- $\alpha$, valamint nitrogén-monoxid fokozott termelődését (Rajora és mtsai, 1997). Az iszkémia következtében fellépő helyi gyulladásos folyamatok csökkentésében is eredményesnek találták a hormont szívben (Vecsernyés és mtsai, 2003, 2017), retinán (Varga és mtsai, 2013) vagy éppen a vesében. A bélrendszerben előforduló iszkémiát követő gyulladásos folyamatokban is az $\alpha-\mathrm{MSH}$ peptid védőhatását az NF- $\kappa \mathrm{B}$ molekula gátlásán keresztül fejtette ki (Hassoun és mtsai, 2002; Zou és mtsai, 2003).

Az $\alpha$-MSH peptidet számos idegrendszeri kórállapot állatmodeljében tesztelték és találták hatásosnak (4. ábra). Neuroprotektív hatását írták le rágcsálókban többek között bakteriális lipopoliszacharid által kiváltott agyi gyulladásban (Rajora és mtsai, 1997), agyi érelzáródás során (Huang és Tatro, 2002), valamint kainsav kiváltotta (Forslin Aronsson és mtsai, 2007) és traumás agysérülésekben (Catania, 2008). A tenyésztett asztrocitákon, idegsejteken és mikrogliákon végzett kísérletekben is a hormon az NF- $\mathrm{B}$ útvonal, a gyulladáskeltő citokinek és nitrogén-monoxid fokozott termelődésének gátlásán keresztül fejtette ki hatását (Catania és mtsai, 2010). 


\section{Célkitüzések}

Az $\alpha$-MSH gyulladáscsökkentő és jótékony hatását már számos, elsősorban állatkísérletes eredmény bizonyítja, azonban annak biológiai gátrendszerek müködésére gyakorolt hatását még nem vizsgálták részleteiben. Célunk tehát az volt, hogy megvizsgáljuk a neuropeptid közvetlen védőhatását a bélhám és a vér-agy gát tenyészetes modelljein, amelyeket gyulladáskeltő citokinekkel kezeltünk. Munkánk során a következö kérdésekre kerestük a választ:

1. Kifejeződik-e a vizsgált biológiai gátrendszerek tenyészetes modelljein az $\alpha-\mathrm{MSH}$ elsődleges és leggyakoribb receptora, az MC1R?

2. Milyen közvetlen hatása van az $\alpha$-MSH peptidnek az agyi endotélsejtek életképességére?

3. Hogyan befolyásolja az $\alpha-\mathrm{MSH}$ a gyulladáskeltő citokinek hatását a biológiai gátrendszerek tenyészetes modelljeinek áteresztőképességére és a sejteket összekötő szoros kapcsolatok morfológiájára?

4. Mi lehet az $\alpha$-MSH védőhatásának mechanizmusa? Gátolja-e az NF- $\kappa B$ transzkripciós faktor sejtmagi bejutását a modellekben, illetve reaktív oxigéngyökök képződését tenyésztett agyi endotélsejtekben? 


\section{Anyagok és módszerek}

\subsection{Vegyszerek}

A kísérleteink során használt minden laborárut, reagenst és vegyszert a SigmaAldrich Kft.-től (a Merck KGaA csoport tagja) szereztük be, amennyiben másképp nem jelöltük.

\subsection{Sejttenyésztés}

\subsubsection{A humán Caco-2 bélepitél-sejtvonal tenyésztése}

A bélepitélium modellezésére a humán Caco-2 béleredetü adenokarcinóma sejtvonalat az ECACC cégtől (\#86010202; European Collection of Authenticated Cell Cultures, Egyesült Királyság) szereztük be. A sejtvonalat kísérletekben 60-as passzázsszámig használtuk, $10 \%$ borjúsavóval (FBS) és gentamicinnel $(50 \mu \mathrm{g} / \mathrm{ml})$ kiegészített tápfolyadékban (Dulbecco módosította Eagle-médium, DMEM) tenyésztettük. A tenyésztési felületeket patkányfarok ínból kinyert kollagénnel vontuk be, hogy a sejtek letapadását és növekedését elősegítsük. A Caco-2 sejtkultúra a 21 napos tenyésztés alatt benőtte a rendelkezésére álló tenyésztőfelületeket és differenciálódott, azaz kialakult a sejtek közötti szoros kapcsolatok szerkezete (5. ábra) és a sejtek apikális-bazális polarizációja.
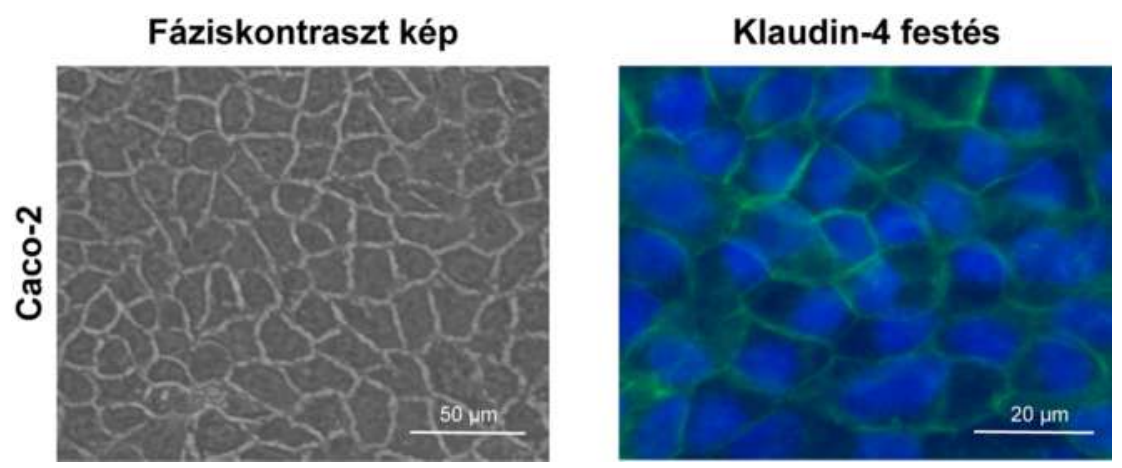

5. ábra. Humán Caco-2 bélepitélsejt-tenyészet fáziskontraszt mikroszkópos képe és immunfestése klaudin-4 TJ fehérjére (Veszelka és mtsai, 2018 alapján).

A bélepitélium gátműködésének vizsgálatához a sejtvonalat permeábilis polikarbonát membránokra $\left(0,4 \mu \mathrm{m}\right.$ pórusméret, $0,33 \mathrm{~cm}^{2}$ felszín; Transwell, Corning Costar, USA) szélesztettük és tenyésztettük. 


\subsubsection{A vér-agy gát in vitro modellezése}

A vér-agy gát modellezésére primer patkány agyi endotélium egysejtrétegét, valamint a permeabilitási teszthez és a sejtkapcsoló fehérjék immunfestéséhez három sejttípusból álló ko-kultúra modellt használtuk, ahol primer patkány agyi endotél-, glia- és pericita sejteket tenyésztettünk együtt. A különböző sejttípusok izolálásának és a modellek összeállításának lépéseit kutatócsoportunk már számos tudományos közleményben leírta (Nakagawa és mtsai, 2009; Veszelka és mtsai, 2013; Walter és mtsai, 2015).

\subsubsection{Agyi endotélsejtek tenyésztése}

A primer agyi endotélsejteket háromhetes Wistar patkányokból izoláltuk szárazjéggel történő túlaltatást követően. A fejek levágása után az agyakat sterilen eltávolítottuk és jéghideg foszfát pufferbe (PBS) helyeztük. Az agyhártyák, a kisagy, a fehérállomány és a plexus choroideus eltávolítása után a megmaradt szürkeállományt szike segítségével apróra daraboltuk, majd pipettázással a szövetet fellazítottuk. A szövetet enzimekkel emésztettük (kollagenáz CLS2, $1 \mathrm{mg} / \mathrm{ml}$; DNáz I, $15 \mu \mathrm{g} / \mathrm{ml}$, Roche, Svájc) $37^{\circ} \mathrm{C}$-on 50 percen át síkrázó készüléken (OS10 orbital shaker, BioSan, Lettország). Ezt követően 20\%-os borjú szérum albumin (BSA) grádiensen háromszori centrifugálással $\left(1000 \mathrm{~g}, 20\right.$ perc, $\left.4{ }^{\circ} \mathrm{C}\right)$ elválasztottuk a nagyobb sürüségü mikroereket az ideg- és gliasejteket tartalmazó, mielingazdag rétegtől. A centrifugálásokból összegyüjtött sejtüledéket ezután $37{ }^{\circ} \mathrm{C}$-on 35 percen keresztül ismét enzimekkel rázatva kezeltük (kollagenáz-diszpáz, $1 \mathrm{mg} / \mathrm{ml}$ és DNáz I, $15 \mu \mathrm{g} / \mathrm{ml}$, Roche, Svájc), ez a lépés elősegíti a mikroereket határoló bazális membrán emésztését, és a perivaszkuláris sejtek elválasztását a mikroérfragmensektől. Végül 33\%-os Percoll grádiens segítségével a mikroérfrakciót elválasztottuk a vörösvérsejtektől, és a sejteket DMEM tápfolyékban kétszer mostuk.

$\mathrm{Az}$ endotélsejteket speciális tenyésztő médiumban vettük fel, amely DMEM/F12 tápoldatot, borjúplazmából készített savót (15\%; First Link Ltd, Egyesült Királyság), valamint bázikus fibroblaszt növekedési faktor (1 $\mathrm{ng} / \mathrm{ml}$; Roche, Svájc), heparin $(100 \mu \mathrm{g} / \mathrm{ml})$, inzulin $(5 \mu \mathrm{g} / \mathrm{ml})$, transzferrin $(5 \mu \mathrm{g} / \mathrm{ml})$, nátrium-szelenit $(5 \mu \mathrm{g} / \mathrm{ml})$ és gentamicin $(50 \mu \mathrm{g} / \mathrm{ml})$ kiegészítőket tartalmazott. Az izolált sejteket IV. típusú kollagén $(100 \mu \mathrm{g} / \mathrm{ml})$ és fibronektin $(100 \mu \mathrm{g} / \mathrm{ml})$ elegyével bevont steril müanyag Petri-csészékbe (Corning Costar, USA) szélesztettük és $\mathrm{CO}_{2}$-inkubátorban tartottuk. A tenyésztés első három napjában $4 \mu \mathrm{g} / \mathrm{ml}$ puromicint adtunk a tápfolyadékhoz, amely ebben a koncentrációban sejtkárosító hatású. Mivel a sejtekből a puromicint hatékonyan eltávolító P-glikoprotein efflux transzporter csak az agyi endotélsejteken fejeződik ki magas szinten, 
az agyi endotélsejtek mellett kis számban jelenlévő más típusú sejteket (pericita, simaizomsejt, fibroblaszt) ez a kezelés eltávolítja (Perrière és mtsai, 2005). Mielőtt a tenyészetek a csészéket teljesen benőtték volna, a sejteket tenyésztőbetétek poliészter membránjára, 96-lyukú tenyésztő lemezekbe (Orange Scientific, USA), vagy üveg fedőlemezekre passzáltuk tripszin $(0,05 \%)$ - EDTA $(0,02 \%)$ oldat segítségével. A tenyésztő felszíneket előzetesen IV. típusú kollagénnel és fibronektinnel vontuk be. Az endotélsejtek a passzálást követő 3-5. napon egybefüggő réteget alkottak, és a tenyészeteket ekkor használtuk fel a kísérletekben (6. ábra).
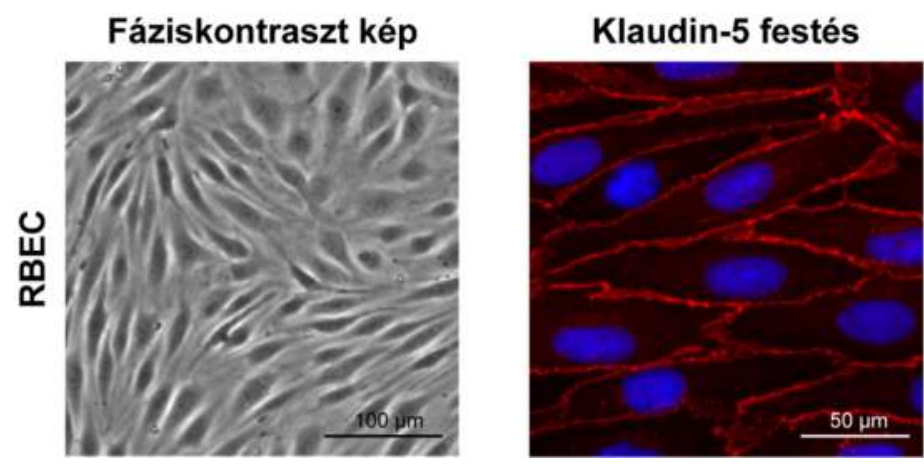

6. ábra. A patkány agyi endotélsejt-tenyészet fáziskontraszt mikroszkópos képe és immunfestése endotélsejt specifikus klaudin-5 TJ fehérjére (Veszelka és mtsai, 2018 alapján).

Az agyi endotélsejtek gát funkciójának erősítése érdekében hidrokortizont (500 $\mathrm{nM})$, valamint a permeabilitási tesztekben a sejtek cAMP-szintjét emelö kezelést ( $250 \mu \mathrm{M}$ CPT-cAMP és 17,5 $\mu \mathrm{M}$ foszfodiészteráz-gátló RO 201724) adtunk a kísérleteket megelőzően 24 órával (Deli és mtsai, 2005; Perrière és mtsai, 2005).

\subsubsection{Agyi mikroér periciták tenyésztése}

A primer patkány agyi periciták izolálása az endotélsejtekkel együtt az előző pontban leírtak alapján történt, azonban a tenyésztés körülményei eltérőek voltak. A periciták tenyésztéséhez a Petri-csészéket nem vontuk be, és a tápfolyadék összetétele is egyszerübb volt (DMEM, 10\% FBS, $50 \mu \mathrm{g} / \mathrm{ml}$ gentamicin). Mivel a periciták nem expresszálnak P-glikoproteint, nem alkalmaztunk puromicinkezelést sem. A periciták lassabb növekedése miatt hosszabb, legalább kéthetes tenyésztési idő után, háromszori passzálást követően használtuk fel a sejteket kísérletekben (Nakagawa és mtsai, 2009). 


\subsubsection{Gliasejtek tenyésztése}

A gliatenyészetek előállításához újszülött (egy- vagy kétnapos) Wistar patkányokat használtunk (Veszelka és mtsai, 2007). Az állatok dekapitálását követően az agyakat jéghideg PBS-be helyeztük, majd steril, nedves szürőpapíron távolítottuk el az agyhártyákat. Ezt követően a szöveteket $10 \mathrm{ml}$ tápfolyadékba gyüjtöttük és steril fecskendőre csatlakoztatott hosszú tüvel $(20 \mathrm{G})$ homogenizáltuk. A szövet mechanikus disszociációját követően a nagyobb aggregátumok leülepedtek, és a szuszpenzió felső részét $(7 \mathrm{ml})$ steril nejlonszürőn $(40 \mu \mathrm{m}$; BD Life Sciences, USA) engedtük át. A homogenizálási lépést még kétszer megismételtük, majd a szürőn átfolyt sejtszuszpenziót DMEM tápfolyadékban történő mosást követően tenyésztőflaskában növesztettük, és előzetesen poli-L-lizinnel bevont 12-lyukú tenyésztőedényekbe (Corning Costar, USA) passzáltuk. A gliatenyészetek átlagosan 2 hét alatt nőtték be a tenyésztőfelszínt, és a 3 . hét után használtuk ko-kultúrához (Veszelka és mtsai, 2007).

\subsubsection{A vér-agy gát ko-kultúra modellje}

A vér-agy gát három sejttípusból álló modelljének létrehozásához együtt tenyésztettük a primer patkány agyi mikroér endotélsejteket és pericitákat, valamint a gliasejteket a csoport által korábban kifejlesztett módszer alapján (Nakagawa és mtsai, 2009). A poliészter membránok $\left(0,4 \mu \mathrm{m}\right.$ pórusméret, $1,12 \mathrm{~cm}^{2}$ felszín; Transwell, Corning Costar, USA) alsó, ún. abluminális felszínére pericitákat szélesztettünk, majd hagytuk a sejteket letapadni 3 órán keresztül $37^{\circ} \mathrm{C}$-on. Ezután a tenyésztőbetéteket a 12-lyukú lemezekben található gliasejtek fölé helyeztük, és a membránok felső, ún. luminális oldalára endotélsejteket pipettáztunk. A három sejttípust ezt követően 3-5 napig tenyésztettük együtt (7. ábra).

\begin{tabular}{|c|c|c|c|c|c|c|c|c|c|c|c|c|c|c|}
\multicolumn{10}{c|}{ mikroérizolálás } & \multicolumn{10}{c}{$\begin{array}{c}\text { tenyésztöbetétre } \\
\text { passzálás }\end{array}$} \\
\hline & $\begin{array}{c}1 . \\
\text { hét }\end{array}$ & $\begin{array}{c}2 . \\
\text { hét }\end{array}$ & $\begin{array}{c}3 . \\
\text { hét }\end{array}$ & $\begin{array}{c}1 . \\
\text { nap }\end{array}$ & $\begin{array}{c}2 . \\
\text { nap }\end{array}$ & $\begin{array}{c}3 . \\
\text { nap }\end{array}$ & $\begin{array}{c}4 . \\
\text { nap }\end{array}$ & $\begin{array}{c}5 . \\
\text { nap }\end{array}$ & $\begin{array}{c}6 . \\
\text { nap }\end{array}$ & $\begin{array}{c}7 . \\
\text { nap }\end{array}$ & $\begin{array}{c}\text { 8. } \\
\text { nap }\end{array}$ & $\begin{array}{c}9 . \\
\text { nap }\end{array}$ & $\begin{array}{c}10 . \\
\text { nap }\end{array}$ & $\begin{array}{c}11 . \\
\text { nap }\end{array}$ \\
\hline gliasejtek & P0 & P0 & P1 & P1 & P1 & P1 & P1 & P1 & P1 & P1 & P1 & P1 & P1 & P1 \\
\hline $\begin{array}{c}\text { agyi mikroér } \\
\text { pericita }\end{array}$ & & P0 & P1 & P2 & P2 & P2 & P2 & P2 & P3 & P3 & P3 & P3 & P3 & P3 \\
\hline $\begin{array}{c}\text { agyi } \\
\text { endotélsejt }\end{array}$ & & & & P0 & P0 & P0 & P0 & P0 & P1 & P1 & P1 & P1 & P1 & P1 \\
\hline
\end{tabular}

7. ábra. Az in vitro vér-agy gát modell összeállításának menete primer agyi endotélsejt-, pericitaés asztrogliatenyészetekből. 
A ko-kultúra során az agyi endotélsejtek vér-agy gát tulajdonságai kifejezettebbekké válnak, a sejtek közötti zárókapcsolatok szorosabbak lesznek, a paracelluláris barrier erősödik és a vér-agy gát müködése szempontjából fontos transzporterek kifejeződése megnő (Nakagawa és mtsai, 2009; Veszelka és mtsai, 2018).

\subsection{Agyi mikroerek izolálása}

Az MC1R mRNS és fehérje kimutatásához felnőtt Wistar patkányokból $\mathrm{CO}_{2}$-dal történő túlaltatását követően agyi mikroereket izoláltunk korábban leírt protokoll alapján (Veszelka és mtsai, 2007). A fejek levágása után az agyakat steril körülmények között eltávolítottuk és jéghideg PBS-be tettük. Az agyhártyákat eltávolítottuk, és az agykéreg szürkeállományát előbb szikével apróra daraboltuk, majd Ringer-HEPES (150 mM NaCl, 2,2 $\mathrm{mM} \mathrm{CaCl}_{2}, 0,5 \mathrm{mM} \mathrm{MgCl}$, 5,2 mM KCl, $6 \mathrm{mM} \mathrm{NaHCO} 3,2,8 \mathrm{mM}$ glükóz, $5 \mathrm{mM}$ HEPES, pH 7,4) pufferben Potter-Elvehjem homogenizáló segítségével a szövetet feltártuk. Ezután 12,5\% dextrán grádiensen háromszori centrifugálással elválasztottuk a nagyobb sürüségü mikroereket a mielintartalmú rétegtől. Az így kapott szuszpenziót először a nagyobb szövetdarabokat elválasztó $100 \mu \mathrm{m}$ nejlonszürön (pluriSelect Life Science, Németország) engedtük át, majd az agyi mikroereket $20 \mu \mathrm{m}$ nejlonszürőn (pluriSelect Life Science, Németország) fogtuk fel. Ringer-HEPES-ben történő mosásokat követően a mikroérmintákat TRI reagensben (Molecular Research Center, USA) homogenizáltuk későbbi RNS-izolálás céljából.

\subsection{Tenyészetek kezelése}

A kísérleteink során a sejttípusok érzékenységétől függően a humán Caco-2 sejtvonalat $10^{-16} \mathrm{M}(100 \mathrm{aM}), 10^{-12} \mathrm{M}(1 \mathrm{pM}), 10^{-8} \mathrm{M}(10 \mathrm{nM})$ és $10^{-4} \mathrm{M}(100 \mu \mathrm{M})$ koncentrációjú $\alpha$-MSH peptiddel kezeltük. A citokinkárosításos kísérletekben 25 ng/ml IL$1 \beta$ és $50 \mathrm{ng} / \mathrm{ml}$ TNF- $\alpha$ koncentrációt alkalmaztunk (Van De Walle és mtsai, 2010), míg $\alpha$ MSH-ból a leghatékonyabb $10^{-8} \mathrm{M}-\mathrm{t}(10 \mathrm{nM})$.

A patkány agyi endotélsejtek esetében a $10^{-12} \mathrm{M}(1 \mathrm{pM}), 10^{-11} \mathrm{M}(10 \mathrm{pM}), 10^{-10} \mathrm{M}$ $(100 \mathrm{pM}), 10^{-8} \mathrm{M}(10 \mathrm{nM})$ és $10^{-6} \mathrm{M}(1 \mu \mathrm{M}) \alpha-\mathrm{MSH}$ koncentrációkat vizsgáltuk. A citokinkárosítást a Caco-2 sejtvonalhoz használt koncentrációból kiindulva különböző kombinációban végeztük: $25 \mathrm{ng} / \mathrm{ml} \mathrm{IL-1} \beta$ és $50 \mathrm{ng} / \mathrm{ml}$ TNF- $\alpha, 25 \mathrm{ng} / \mathrm{ml} \mathrm{IL-1 \beta}$ és $25 \mathrm{ng} / \mathrm{ml}$ TNF- $\alpha, 10$ ng/ml IL-1 $\beta$ és 25 ng/ml TNF- $\alpha$, valamint 10 ng/ml IL-1 $\beta$ és 10 ng/ml TNF- $\alpha$ kombinációkkal kezeltük az agyi endotélsejteket. További kísérletekhez a leghatékonyabb 
$10^{-12} \mathrm{M}(1 \mathrm{pM})$ és $10^{-11} \mathrm{M}(10 \mathrm{pM}) \alpha-\mathrm{MSH}$ és a legalacsonyabb $10 \mathrm{ng} / \mathrm{ml} \mathrm{IL}-1 \beta$ és 10 ng/ml TNF- $\alpha$ koncentrációkat alkalmaztuk.

A kontrollcsoport mindkét modellnél kezelést nem, csak tápfolyadékot kapott, azonban minden más körülményben azonosan tenyésztett és vizsgált sejteket tartalmazott.

\subsection{Reverz transzkripciót követő polimeráz láncreakció}

Az Mclr gén aktivitásának vizsgálatához agyi mikroereket izoláltunk Wistar patkányokból, valamint patkány agyi endotélsejteket tenyésztettünk $6 \mathrm{~cm}$-es Petricsészékben (Corning Costar, USA). PBS-mosást követően a szövet- és a sejtmintákat TRI reagensben (Molecular Research Center, USA) homogenizáltuk. Ezt követően a gyártó protokollja szerint az össz-RNS-t kloroformmal kivontuk, izopropanollal kicsaptuk és $80 \%$ etanollal mostuk. Nanodrop ND-1000 (NanoDrop Technologies, USA) müszerrel történő koncentrációmérést követően az össz-RNS-ek 1-1 $\mu$ g-ját DNáz enzimmel (ThermoFisher, USA) kezeltük, majd cDNS-szintézis kit (ThermoFisher, USA) segítségével reverz transzkripciót végeztünk a gyártó utasításainak megfelelően. Az Mclr és referenciaként használt $\beta$-aktin (Act) gének vizsgálatára specifikus oligonukleotid primereket terveztünk (4. táblázat) az NCBI adatbázisban található referenciaszekvenciák segítségével.

4. táblázat. A PCR reakciókhoz használt oligonukleotid primerek.

\begin{tabular}{|l|r|l|}
\hline Mc1r & referenciagén: & XM_006222790 \\
\hline fwd & 5'-tgcacctcttgctcatcgtt-3' & \\
\hline rvs & 5'-acctccttgagtgtcatgcg-3' & \\
\hline & amplikonhossz: & 160 bp \\
\hline Act & referenciagén: & NM_031144 \\
\hline fwd & 5'-tactctgtgtggattggtggc-3' & \\
\hline rvs & 3'-ggtgtaaaacgcatctcagtaa-3' & \\
\hline & amplikonhossz: & 150 bp \\
\hline
\end{tabular}

A génaktivitás vizsgálatához polimeráz láncreakciókat $(\mathrm{PCR})$ végeztünk BioRad T100 PCR-müszer (Bio-Rad Laboratories, USA) és FIREPol DNS polimeráz (Solis BioDyne, Észtország) segítségével. A kezdeti hőinaktiválást $\left(95^{\circ} \mathrm{C}, 3\right.$ perc) követően a következő, 35 alkalommal ismétlődő ciklust állítottuk be: denaturáció $94{ }^{\circ} \mathrm{C}$-on 15 másodpercig, primertapadás $50{ }^{\circ} \mathrm{C}$-on 15 másodpercig, polimerizáció $94{ }^{\circ} \mathrm{C}$-on 20 másodpercig. A $72{ }^{\circ} \mathrm{C}-\mathrm{os} 5$ percig tartó utópolimerizációt követően 3\% MetaPhor agaróz 
gélen (Cambrex BioScience, USA) azonosítottuk a kapott amplikonokat. A PCRfragmenteket kapilláris szekvenálással igazoltuk.

\section{6. Életképességi vizsgálatok}

\subsubsection{MTT-teszt}

Az $\alpha$-MSH patkány agyi endotélsejtek életképességére gyakorolt hatásának vizsgálatára festékredukciós tesztet használtunk. Az élő, aktív anyagcserét folytató sejtek enzimei a sárga 3-(4,5-dimetiltiazol-2-il)-2,5-difeniltetrazólium-bromid (MTT) festéket kékszínü formazán kristályokká alakítják át. A toxikus, sejtkárosító hatás mértékével arányosan csökken a festék redukciója, amely spektrofotométeres visszamérést követően számszerüsíthető (Kiss és mtsai, 2013).

A vizsgálathoz az agyi endotélsejteket 96-lyukú lemezeken tenyésztettük $\left(5 \times 10^{3}\right.$ sejt/lyuk kiindulási sejtszám), amíg be nem nőtték a tenyésztőfelületet. Ezt követően a sejteket 24 órán keresztül különböző koncentrációjú $\alpha-M S H-v a l$ kezeltük. A kezelés után a sejtekhez adtuk az MTT-oldatot $(0,5 \mathrm{mg} / \mathrm{ml})$ és 3 órán keresztül $37^{\circ} \mathrm{C}$-on inkubáltuk. A festékből képződött formazánkristályokat dimetil-szulfoxidban oldottuk fel és a formazán mennyiségét abszorbanciaméréssel határoztuk meg többlyukú lemezleolvasó készülék (BMG Fluostar Optima, BMG Labtech, Németország; hullámhossz: 595 nm) segítségével.

\subsubsection{Valósidejü sejtanalízis}

Az impedancia-mérésen alapuló RTCA-SP rendszer (ACEA Biosciences, USA) alkalmas sejttenyészetek biológiai állapotának, növekedésének, életképességének, letapadásának jelzőanyag nélküli, valósidejü nyomon követésére (8. ábra). A sejtek vizsgálata fiziológiás körülmények között zajlik folyamatos monitorozás mellett. Ezt a módszert csoportunk már számos kísérletben alkalmazta (Kiss és mtsai, 2013). Az agyi endotélsejteket egy speciális 96-lyukú tenyésztőlemezre (E-plate, ACEA) szélesztettük, amelynek alján arany mikroelektromos szenzorok, mikroelektródák vannak, melyek impedancia mérésére alkalmasak. A háttér-impedancia meghatározása után a sejtek növekedésével és letapadásával arányosan emelkedik a mért impedancia, amit a rendszer programja a sejtindex értékével fejez ki. A szoftver a sejtindexet az $\left(R_{n}-R_{b}\right) / 15$ képlet segítségével határozza meg, ahol $\mathrm{R}_{\mathrm{n}}$ a sejtek és az elektród között mért impedancia, $a z \mathrm{R}_{\mathrm{b}}$ pedig a háttér-impedancia. 


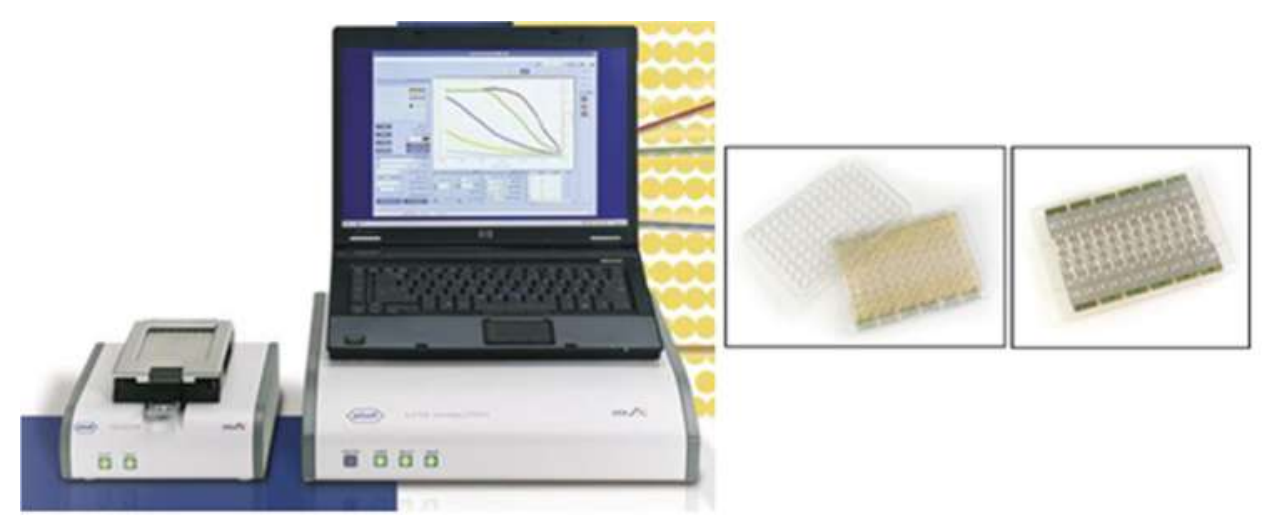

8. ábra. Valósidejü sejtanalizáló készülék (RTCA-SP, ACEA, www.aceabio.com/products/rtca$\mathrm{sp})$.

A kísérlethez az E-plate lemezek lyukait IV. típusú kollagénnel $(100 \mu \mathrm{g} / \mathrm{ml})$ és fibronektinnel $(100 \mu \mathrm{g} / \mathrm{ml})$ vontuk be, majd UV alatt történő szárítást követően tápfolyadék hozzáadása után lemértük a háttér-impedanciát. Ezt követően mértük a lyukakba a sejtszuszpenziót $\left(5 \times 10^{3}\right.$ sejt/lyuk kiindulási sejtszám), majd az agyi endotélsejteket $37{ }^{\circ} \mathrm{C}$-os $\mathrm{CO}_{2}$-inkubátorban tenyésztettük, amíg a sejtek benőtték a tenyésztőfelszínt, és az impedancia nem nőtt tovább (platófázis). Ekkor a sejteket vagy $\alpha$ MSH peptiddel $\left(10^{-12}-10^{-6} \mathrm{M}\right)$, vagy egyórás $\alpha$-MSH $\left(10^{-12}-10^{-11} \mathrm{M}\right)$ elökezelést követően IL-1 $\beta$ és TNF- $\alpha(10-10 \mathrm{ng} / \mathrm{ml})$ citokinekkel kezeltük. A müszer a sejtindexet ezután 24 órán keresztül 10 percenként rögzítette. Az impedancia-értékeket a kezelés előtti utolsó időpont értékeihez normalizáltuk és a kapott értékeket az idő függvényében ábrázoltuk.

\subsection{Biológiai gátrendszerek müködésének vizsgálata}

\subsubsection{Transzepiteliális elektromos ellenállás mérése}

A bélepitélsejtek közötti szoros sejtkapcsoló struktúrák korlátozzák az anyagok paracelluláris átjutását. A tenyészetekben mért transzepiteliális elektromos ellenállás (TEER) értéke a sejtek szoros kapcsolatainak a tenyésztő és a pufferoldatokban a legnagyobb, $150 \mathrm{mM}$ koncentrációban jelen lévő kationnal, a nátriumionnal szembeni áteresztőképességét fejezi ki (Benson és mtsai, 2013). A humán Caco-2 sejtvonal ellenállásértékeit Millicell-ERS rezisztenciamérővel és mérőelektróddal (Millipore, USA) vizsgáltuk. A mért TEER értékeket a sejtmentes filter ellenállásértékének levonását követően a tenyésztőmembrán felszínéhez viszonyítva $\left(\Omega \times \mathrm{cm}^{2}\right)$ átlagoltuk és ábrázoltuk. 


\subsubsection{Permeabilitási vizsgálat}

A gátrendszerek modelljeinek permeabilitási vizsgálatát különböző nagyságú jelzőanyagok használatával végeztük (9. ábra). A paracelluláris útvonalon való átjutás mértékének meghatározása humán Caco-2 bélepitélsejtréteg esetében fluoreszcein (SF, $376 \mathrm{Da}$ ), patkány vér-agy gát ko-kultúra modell esetében fluoreszcein-izotiocianáttal jelölt dextrán (FITC-dextrán, 4,4 kDa) segítségével történt. A másik marker a szérum albuminhoz kötött Evans-kék festék (EBA, 67 kDa) volt.

A Caco-2 bélepitélsejteket 24 órán át kezeltük IL-1 $\beta$ és TNF- $\alpha$ citokinekkel $\alpha-M S H$ hozzáadásával vagy anélkül. Ezt követően a tenyésztőbetéteket 24-lyukú lemezekbe helyeztük, amely lyukanként $530 \mu \mathrm{l}$ steril $37^{\circ} \mathrm{C}$-os Ringer-HEPES-oldatot tartalmazott. A felső kompartmentben a tápfolyadékot $70 \mu$ jelzőanyagokat tartalmazó Ringer-HEPESoldatra cseréltük (fluoreszcein $10 \mu \mathrm{g} / \mathrm{ml}$, Evans-kék 167,5 $\mu \mathrm{g} / \mathrm{ml}$, BSA $1 \mathrm{mg} / \mathrm{ml}$ ). A tenyésztőedényeket 1 órán keresztül $37^{\circ} \mathrm{C}$-on $\mathrm{CO}_{2}$-inkubátorban síkrázó készüléken (100 fordulat/perc; OS10 orbital shaker, BioSan, Lettország) tartottuk. Az enyhe rázással biztosítottuk az oldatok folyamatos mozgatását, ami a permeabilitásmérés elengedhetetlen része (Youdim és mtsai, 2003).

Patkány vér-agy gát ko-kultúra modelljét 1 órán át kezeltük gyulladáskeltő citokinekkel $\alpha-\mathrm{MSH}$ jelenlétében vagy anélkül. Ezután a tenyésztőbetéteket a sejtrétegekkel 12-lyukú lemezekbe helyeztük, amely lyukanként $1500 \mu \mathrm{l}$ steril $37^{\circ} \mathrm{C}$-os Ringer-HEPES-oldatot tartalmazott. A felső kompartmentben a tápfolyadékot $500 \mu \mathrm{l}$ jelzőanyagokat tartalmazó Ringer-HEPES-oldatra cseréltük (FITC-dextrán $100 \mu \mathrm{g} / \mathrm{ml}$, Evans kék $167,5 \mu \mathrm{g} / \mathrm{ml}$, BSA $1 \mathrm{mg} / \mathrm{ml}$ ), és a tenyésztőedényeket 30 percre $37^{\circ} \mathrm{C}$-os $\mathrm{CO}_{2^{-}}$ inkubátorba síkrázó készülékre tettük.
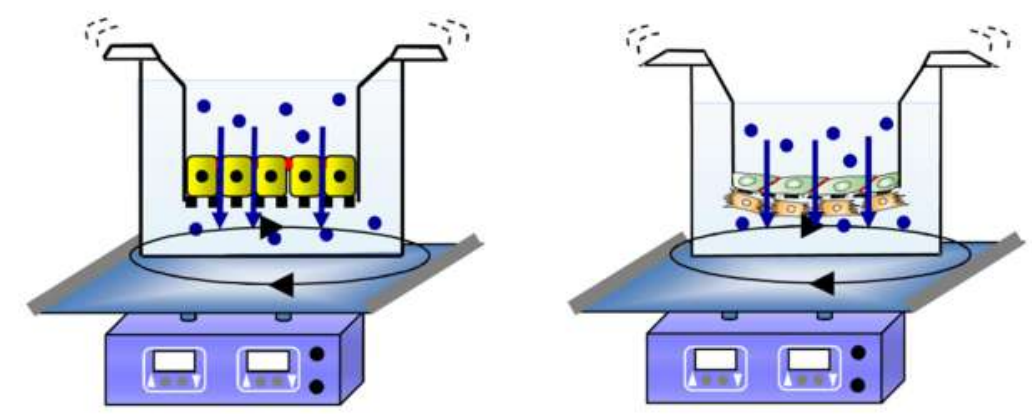

9. ábra. Permeabilitási vizsgálatok tenyésztett bélepitélsejteken és in vitro vér-agy gát modellen. 
A jelzőanyagok koncentrációját a felső és az alsó kompartmentekből vett mintákból többlyukú lemezleolvasóval (BMG Fluostar Optima, BMG Labtech, Németország) határoztuk meg. A fluoreszcein emisszióját $485 \mathrm{~nm}$ hullámhosszon történő excitációt követően 520 nm-en, míg az EBA elnyelését 584 nm-en történt gerjesztés után 680 nm-en mértük.

A látszólagos permeabilitási együtthatót $\left(\mathrm{P}_{\mathrm{app}}\right)$ a következő képlet segítségével határoztuk meg:

$$
\mathrm{P}_{\text {app }}=\frac{[C]_{B} \times V_{B}}{A \times[C]_{A} \times t}
$$

ahol $[\mathrm{C}]_{\mathrm{B}}$ az alsó kompartment mintáiban mért jelzőanyag-koncentráció, $[\mathrm{C}]_{\mathrm{A}}$ a felső kompartmentbe mért kiindulási jelzőanyag-koncentráció, $V_{B}$ az alsó kompartment térfogata $(0,53 \mathrm{ml}$ vagy $1,5 \mathrm{ml})$, A a membrán felszíne $\left(0,33 \mathrm{~cm}^{2}\right.$ vagy $\left.1,12 \mathrm{~cm}^{2}\right)$ és $\mathrm{t}$ a permeabilitás vizsgálat időbeni hossza (1 óra vagy 30 perc).

\subsection{Reaktív oxigéngyök képződés}

Az agyi endotélsejtekben a reaktív oxigéngyökök (ROS) képződésének meghatározására a 2',7'-dikloro-dihidro-fluoreszcein diacetát próbát (DCFDA; Molecular Probes, USA) használtunk. Ez a nem fluoreszcens molekula átjut a sejtmembránon, majd a citoplazmában reakcióba lép az ott lévő észterázokkal, amelyek lehasítják róla az acetát- és észtercsoportokat és töltést kap. Az így képződött metabolit felhalmozódik a sejtben és a reaktív oxigéngyökökkel kapcsolatba lépve fluoreszcens vegyületté alakul, a fluoreszcencia intenzitása pedig spektrofotométerrel mérhető.

A patkány agyi endotélsejteket $\alpha$-MSH-val és gyulladáskeltő citokinekkel önállóan és együtt kezeltük 96-lyukú tenyésztőlemezeken 1 órán keresztül. A kezelőoldatokat DCFDA-t $(2 \mu \mathrm{M})$ tartalmazó Ringer-HEPES oldatra cseréltük és a sejteket újabb 1 órán át inkubáltuk, miközben 5 percenként fluoreszcencia-intezitást mértünk fluoreszcens leolvasó készülékkel (BMG Fluostar Optima, Németország; gerjesztési hullámhossz: $485 \mathrm{~nm}$, elnyelési hullámhossz: $520 \mathrm{~nm}$ ). Referenciavegyületként hidrogénperoxid-oldatot (100 $\mu \mathrm{M})$ használtunk. 


\subsection{Immunhisztokémia}

\subsubsection{MC1R fehérje immunfestése}

A Caco-2 epitélsejtek tenyészeteit PBS-mosást követően 4\% paraformaldehidoldattal fixáltuk 20 percig szobahőmérsékleten, majd $0,2 \%$ Triton-X-oldattal permeabilizáltuk 10 percig $4{ }^{\circ} \mathrm{C}$-on. A nem specifikus kötőhelyeket $3 \%$ BSA-val blokkoltuk 1 órán át szobahőmérsékleten. A nyúl anti-humán MC1R elsődleges ellenanyaggal $(1 \mu \mathrm{g} / \mathrm{ml}) 1$ éjszakán keresztül $4^{\circ} \mathrm{C}$-on, az Alexa Fluor 488 jelölt anti-nyúl másodlagos ellenanyaggal $(2 \mu \mathrm{g} / \mathrm{ml})$ és propídium-jodid $(1 \mu \mathrm{M})$ sejtmagfestékkel 1 órán át szobahőmérsékleten inkubáltuk a mintákat. Az ellenanyagokkal történő kezelések között és után háromszor mostuk PBS-ben a sejteket, majd a mintákat lefedtük (Fluoromount-G, Southern Biotech, USA) és Olympus FV1000 konfokális mikroszkóppal (Olympus Corporation, Japán) vizsgáltuk.

Az agyi pericitákkal és a gliasejtekkel együtt-tenyésztett patkány agyi endotélsejteket és a frissen izolált patkány agyi hajszálereket PBS-mosás után jéghideg aceton-metanol 1:1 arányú elegyével fixáltuk 5 percig szobahőmérsékleten. A nem specifikus kötőhelyeket 3\% BSA-val blokkoltuk 1 órán át szobahőmérsékleten. A nyúl anti-humán MC1R elsődleges ellenanyaggal ( $5 \mu \mathrm{g} / \mathrm{ml}) 1$ éjszakán keresztül $4{ }^{\circ} \mathrm{C}$-on, az Alexa Fluor 488 jelölt anti-nyúl másodlagos ellenanyaggal $(2,5 \mu \mathrm{g} / \mathrm{ml})$ és etídiumhomodimer $(1 \mu \mathrm{M})$ sejtmagfestékkel 1 órán át szobahőmérsékleten inkubáltuk a mintákat. Az ellenanyagokkal történő kezelések között és után háromszor mostuk PBS-ben a mintákat, majd lefedtük (Fluoromount-G, Southern Biotech, USA). A patkány agyi endotélsejtek és hajszálerek esetében Leica SP5 konfokális mikroszkóp (Leica Camera AG, Németország) segítségével készítettünk fluoreszcens és differenciális interferencia kontraszt mikroszkópos képeket.

\subsubsection{Sejtkapcsoló fehérjék immunfestése}

A tenyészetekben a sejtek közötti szoros kapcsolatok szerkezetét egyes sejtkapcsoló fehérjék immunhisztokémiai festésével vizsgáltuk. A Caco-2 epitélsejteket a kezelések végén PBS-mosás után aceton-metanol 1:1 arányú elegyével fixáltuk 5 percig szobahőmérsékleten, majd a nem specifikus kötőhelyeket 3\% BSA-val blokkoltuk 1 órán át. Az elsődleges ellenanyaggal való festés nyúl anti-humán ZO-1 és nyúl anti-humán klaudin-4 ellenanyagokkal $(2,5 \mu \mathrm{g} / \mathrm{ml}$; Thermo Fisher Scientific, USA) történt 1 éjszakán keresztül $4{ }^{\circ} \mathrm{C}$-on. Másodlagos ellenanyaggal történő festéskor Alexa Fluor 488 jelölt antinyúl ellenanyagot ( $1 \mu \mathrm{g} / \mathrm{ml}$; Thermo Fisher Scientific, USA) és H33342 sejtmagfestéket (1 
$\mu \mathrm{g} / \mathrm{ml}$ ) használtunk 1 órán át szobahőmérsékleten. Az ellenanyagokkal történő kezelések között és után háromszor mostuk PBS-ben a mintákat, majd lefedtük (Fluoromount-G, Southern Biotech, USA).

A patkány agyi endotélsejteket a kezelések után PBS-mosást követően jéghideg aceton-metanol 1:1 arányú elegyével fixáltuk 5 percig szobahőmérsékleten, majd a nem specifikus kötőhelyeket 3\% BSA-val blokkoltuk 1 órán át. A nyúl anti-patkány klaudin-5 és a nyúl anti-patkány $\beta$-katenin elsődleges ellenanyagokkal $(2,5 \mu \mathrm{g} / \mathrm{ml}) 1$ éjszakán keresztül inkubáltuk a mintákat $4{ }^{\circ} \mathrm{C}$-on. Másnap a Cy3-jelölt anti-nyúl másodlagos ellenanyaggal $(1 \mu \mathrm{g} / \mathrm{ml})$ és H33342 $(1 \mu \mathrm{g} / \mathrm{ml})$ sejtmagfestékkel 1 órán át kezeltük a mintákat szobahőmérsékleten. Az ellenanyagokkal történő kezelések között és után háromszor mostuk PBS-ben a mintákat, majd lefedtük (Fluoromount-G, Southern Biotech, USA).

Az immunhisztokémiai festésekről Leica SP5 konfokális mikroszkóp (Leica Camera AG, Németország) segítségével készítettünk képeket. A patkány agyi endotélsejtek festődésváltozásának mennyiségi analízisét MATLAB program (MathWorks, USA) segítségével végeztük. A készített képek nem egyenletes hátterét a program segítségével meghatároztuk és kivontuk az eredetiből, majd a szürkeárnyalatos képeket binárissá alakítottuk. A 6 pixelnél kisebb objektumokat eltávolítottuk, hogy csökkentsük a hamis struktúrák számát, majd a struktúraméreteket meghatároztuk a bináris képek pixelszámai alapján. Az objektumszám az egymástól különálló, azaz egymáshoz nem kapcsolódó struktúrák számát fejezi ki az immunhisztokémiai képeken.

\subsubsection{Az NF-кB transzkripciós faktor sejtmagba történő bejutásának vizsgálata}

Az NF- $\mathrm{B}$ transzkripciós faktor sejtmagba történő bejutását mind epitél, mind agyi endotélsejteken kezelést követően hasonló módszerrel vizsgáltuk. A sejteket PBS-mosás után jéghideg aceton-metanol 1:1 arányú elegyével 5 percig fixáltuk, majd a nem specifikus kötőhelyeket 3\% BSA-val blokkoltuk 1 órán át szobahőmérsékleten. A nyúl

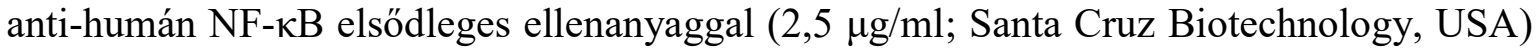
1 éjszakán keresztül $4{ }^{\circ} \mathrm{C}$-on inkubáltuk a mintákat. Másnap Alexa Fluor 488 jelölt antinyúl ellenanyaggal ( $1 \mu \mathrm{g} / \mathrm{ml}$; Thermo Fisher Scientific, USA) és H33342 (1 $\mu \mathrm{g} / \mathrm{ml})$ sejtmagfestékkel 1 órán át kezeltük a mintákat szobahőmérsékleten. Az ellenanyagokkal történő kezelések között és után háromszor mostuk PBS-ben a mintákat, majd lefedtük (Fluoromount-G, Southern Biotech, USA). 
Az NF-кB jelölödésének intenzitását Leica SP5 konfokális mikroszkóp (Leica Camera AG, Németország) segítségével végeztük. A citoplazmás és sejtmagi NF-кB festődésintezitás vizsgálatát Caco-2 sejtvonal esetében ZEN 2012 v.1.1.0.0. szoftver (Carl Zeiss AG, Németország), a patkány agyi endotélsejtek esetében ImageJ programmal (National Institute of Health, USA) végeztük (Sántha és mtsai, 2016).

\subsection{Statisztikai kiértékelés}

A statisztikai kiértékeléshez a GraphPad Prism 5.0 (GraphPad Software Inc., USA) programot használtuk. A kísérletekben kapott adatokat átlag \pm S.E.M. (az átlag standard hibája) formában adtuk meg.

Az egyes kezelési csoportok közötti különbségeket egyutas ANOVA-t követően Bonferroni-teszttel elemeztük. Statisztikailag szignifikánsnak a $\mathrm{P}<0.05$ értékeket tekintettük. A kísérleteket legalább háromszor megismételtük, és kísérletenként legalább három párhuzamos mintát használtunk. 


\section{Eredmények}

\subsection{MC1R fehérje jelenléte bélepitél- és agyi endotélsejteken}

Az $\alpha$-MSH peptid hatásának közvetítésében szerepet játszó elsődleges receptor az MC1R, melynek kifejeződését sikeresen kimutattuk a biológiai gátrendszerek mindkét tenyészetes modelljén.

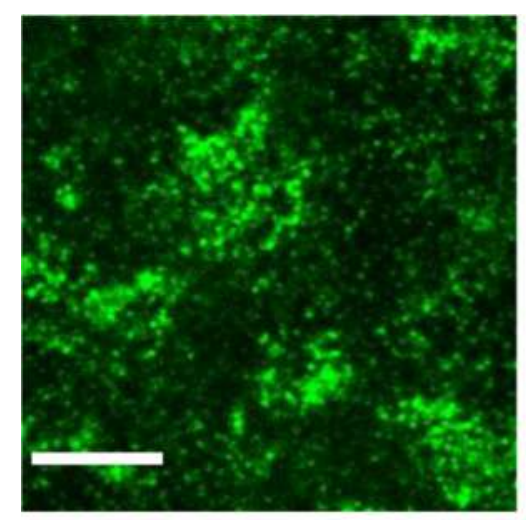

Apikális felszín

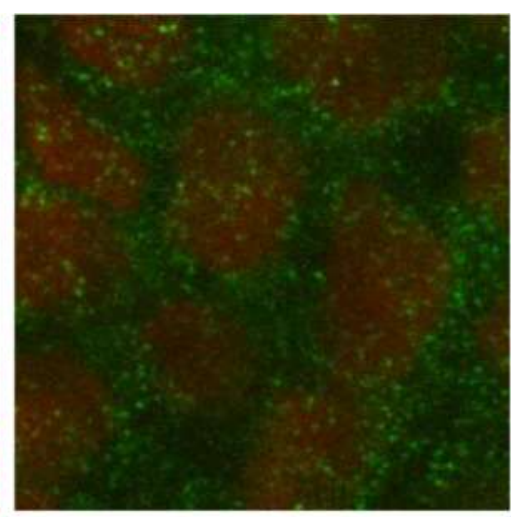

Bazális felszín

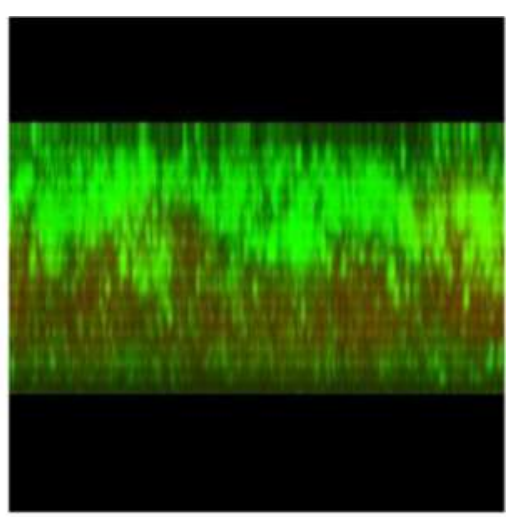

Horizontális metszet

10. ábra. Melanokortin-1 receptor (MC1R) immunfestése humán Caco-2 bélepitélsejteken konfokális mikroszkópos képeken. Zöld: MC1R; piros: sejtmag. Mérce: $5 \mu \mathrm{m}$.

A Caco-2 bélepitélsejtekben mind az apikális, mind a bazális felszínen kimutatható volt a receptorfehérje jelenléte immunhisztokémiai festéssel (10. ábra). A fluoreszcens festődés sokkal kifejezettebbnek bizonyult az apikális felszínen a bazális oldalhoz viszonyítva, ami a konfokális mikroszkóppal készített képekből összerakott horizontális metszeten is jól látszott.

Az MC1R gén termékét mind a tenyésztett patkány agyi endotélsejtekben, mind az izolált patkány agyi mikroerekben kimutattuk reverz transzkripciót követő PCR segítségével (11A ábra). A génaktivitási vizsgálat eredményét igazolta az MC1R immunhisztokémiai festés is, ahol mind a tenyésztett endotélsejtekben (11B ábra), mind az izolált agyi hajszálerek endotélsejtjeiben (11C ábra) jól látható jelet kaptunk. 

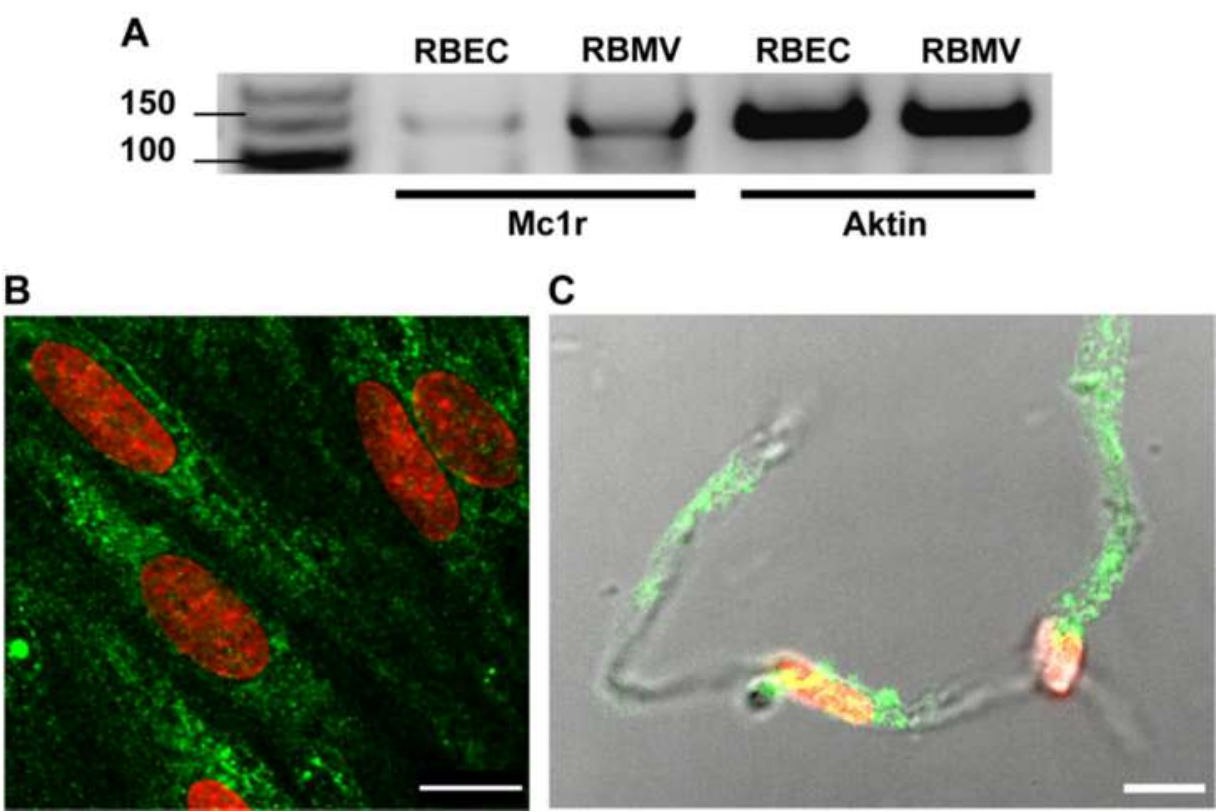

11. ábra. Melanokortin-1 receptor $(\mathrm{MC} 1 \mathrm{R})$ expressziója patkány agyi endotélsejten és izolált patkány agyi hajszáléren. A) Reverz transzkripciót követő polimeráz láncreakció. RBEC: patkány agyi endotélsejt; RBMV: izolált patkány agyi hajszálér. B) Patkány agyi endotélsejt MC1R immunhisztokémia. Zöld: MC1R; piros: sejtmag. Mérce: $10 \mu \mathrm{m}$. C) Izolált patkány agyi hajszálér MC1R immunhisztokémia. Zöld: MC1R; piros: sejtmag. Mérce: $5 \mu \mathrm{m}$.

\subsection{Az $\alpha$-MSH hatása agyi endotélsejt-tenyészeteken}

Az $\alpha$-MSH peptid patkány agyi endotélsejtekre gyakorolt önálló hatását impedanciaalapú valósidejü sejtanalízissel és végponti analízist lehetővé tevő MTT-teszttel vizsgáltuk. Különböző koncentrációjú (1 pM - $1 \mu \mathrm{M}) 24$ órás peptidkezelés nem változtatta meg szignifikánsan a sejtek életképességét. Az impedanciamérések során a kezelt agyi endotélsejtek görbéi a kezeletlen kontrollcsoport görbéivel futottak együtt (12A ábra), ami életképes, a felszínre jól letapadt, egymáshoz szorosan kapcsolódó sejtekből álló tenyészetekre utalt. Mindezt megerősítette az MTT-teszt eredménye, amellyel semmilyen metabolikus aktivitásban bekövetkezett változást nem mutattunk ki a kezeletlen kontrollcsoporthoz viszonyítva 24 órás $\alpha$-MSH-kezelést követően (12B ábra). Az eredmények alapján a patkány agyi endotélsejteken további kísérleteinkben $10^{-12} \mathrm{M}(1 \mathrm{pM})$ és $10^{-11} \mathrm{M}(10 \mathrm{pM})$ koncentrációjú $\alpha$-MSH-kezelést alkalmaztunk, amely tartomány megfelel a neurohormon vérben mérhető élettani koncentrációinak (Kovács és mtsai, 2001; Magnoni és mtsai, 2003). 

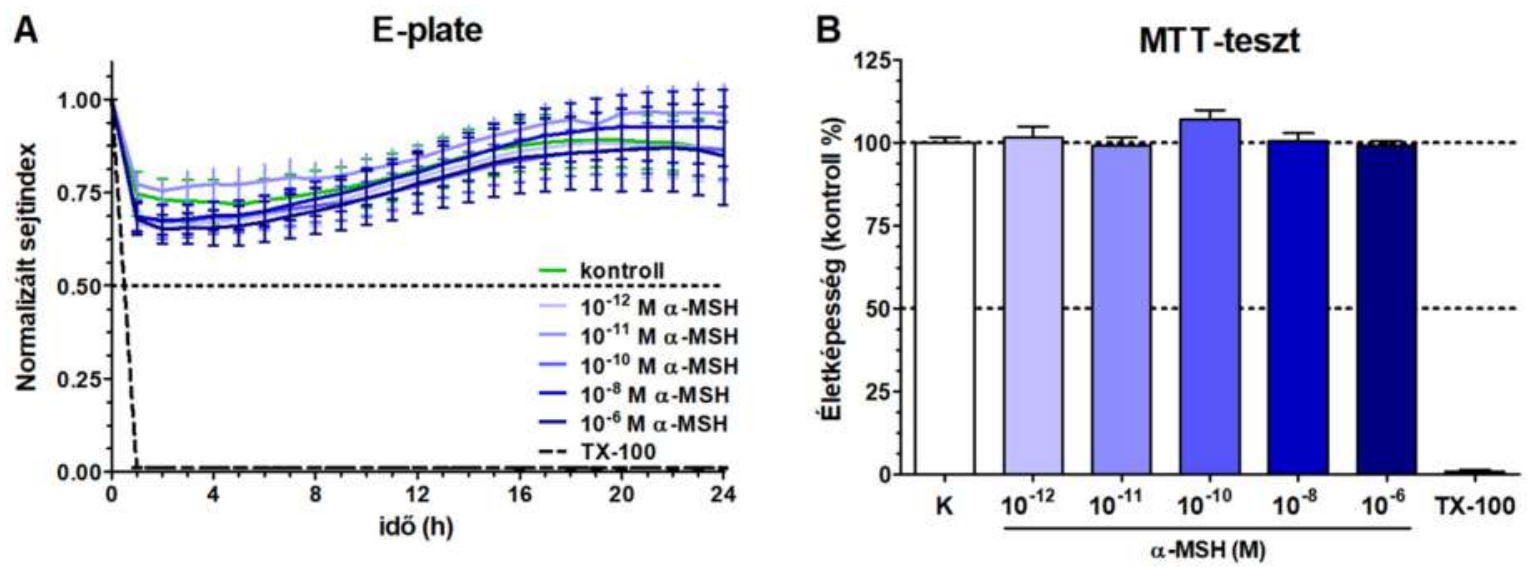

12. ábra. Az $\alpha$-MSH különbözö koncentrációinak hatása tenyésztett patkány agyi endotélsejtek életképességére. A) Valósidejü sejtanalízis. B) MTT-teszt. Statisztika: egyutas ANOVA és Bonferroni-teszt.

\subsection{A citokinek és az $\alpha$-MSH hatása agyi endotélsejt-tenyészetek életképességére}

A gyulladáskeltő citokinek megfelelő kezelési koncentrációjának meghatározásához patkány agyi endotélsejteket kezeltünk négy különböző kombinációban. A Caco-2 bélepitélsejteken alkalmazott $50 \mathrm{ng} / \mathrm{ml}$ TNF- $\alpha$ és $25 \mathrm{ng} / \mathrm{ml}$ IL-1 $\beta$ koncentrációtól kezdve a $25+25 \mathrm{ng} / \mathrm{ml}$ kezelési koncentráción át, az alacsonyabb $10 \mathrm{ng} / \mathrm{ml}$ TNF- $\alpha$ és 25 ng/ml IL-1 $\beta$ és $10+10 \mathrm{ng} / \mathrm{ml}$ koncentrációig (13. ábra). Mind a négy kezelési kombináció esetén 24 órás kezelést követően statisztikailag szignifikánsan csökkent a patkány agyi endotélsejtek valósidejü sejtanalízis során mérhető sejtindexe. A négy kezelési csoport hatásai között pedig nem volt statisztikailag szignifikáns különbség. A patkány agyi endotélsejteken további kísérleteinkben a 10+10 ng/ml koncentrációjú, azonos hatást kiváltó legkisebb koncentrációjú citokinkezelést alkalmaztuk.

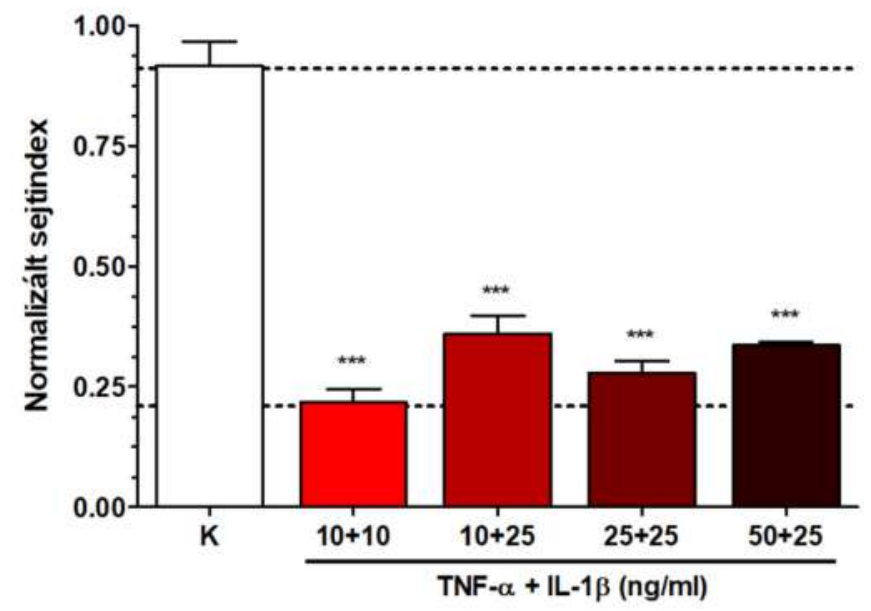

13. ábra. Különböző koncentrációjú citokinkoktélok hatása tenyésztett patkány agyi endotélsejtek életképességére. Statisztika: ***, P $<0,001$ a kontrollcsoporthoz képest, egyutas ANOVA és Bonferroni-teszt. 
Patkány agyi endotélsejteket $10+10 \mathrm{ng} / \mathrm{ml} \mathrm{TNF}-\alpha$ és IL-1 $\beta$ kombinációval kezelve már a kezelés kezdetétől számított 6 órán belül $50 \%$ alá esett a sejtindex, ezt a károsító hatást az $\alpha$-MSH-kezelés csökkentette (14A ábra). Az $\alpha$-MSH kis koncentrációjú (1 pM) alkalmazása statisztikailag szignifikáns védőhatást mutatott a citokinindukált életképességcsökkenés ellen (14B ábra). A citokinekkel és az $\alpha$-MSH peptiddel együtt kezelt két kísérleti csoport között nem volt statisztikailag kimutatható különbség.

A

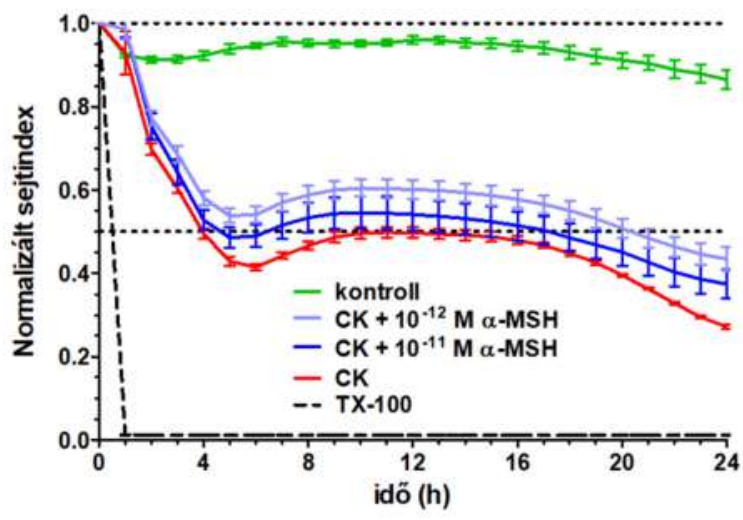

B

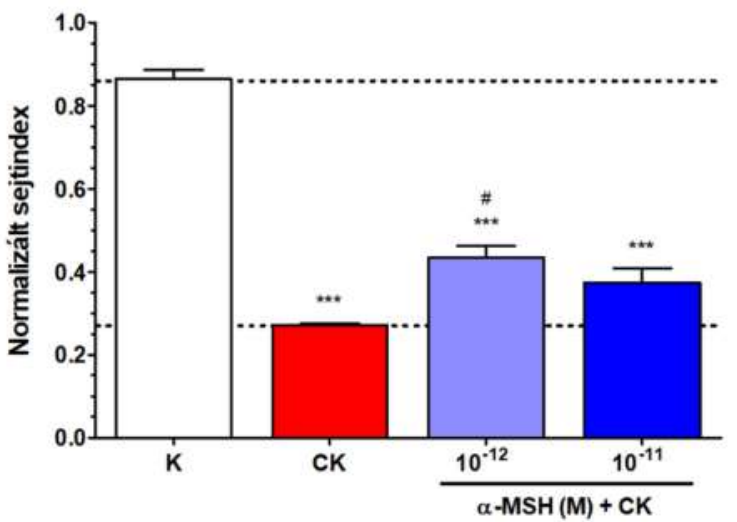

14. ábra. Az $\alpha$-MSH hatása citokinekkel kezelt tenyésztett patkány agyi endotélsejtek életképességére. A) Valósidejü sejtanalízis időbeli lefutása. B) Valósidejủ sejtanalízis a 24-órás kezelés utáni időpontban. CK: $10 \mathrm{ng} / \mathrm{ml}$ TNF- $\alpha+10 \mathrm{ng} / \mathrm{ml}$ IL-1 $\beta$. Statisztika: ***, P $<0,001 \mathrm{a}$ kontrollcsoporthoz képest; \#, $\mathrm{P}<0,05$ a citokinkezelt csoporthoz képest, egyutas ANOVA és Bonferroni-teszt.

\subsection{A citokinek és az $\alpha$-MSH hatása a biológiai gátrendszerek tenyészetes modelljeinek integritására}

\subsubsection{Transzepiteliális elektromos ellenállás}

A biológiai gátrendszereket alkotó epitél- és endotélsejtrétegek szorosságát a sejtréteg két oldala között mérhető magas ellenállás jellemzi. Ennek fizikai alapja, hogy a sejteket összekapcsoló TJ fehérjék megakadályozzák az ionok paracelluláris szabad áramlását. A Caco-2 bélepitél-sejtvonalon alkalmazott citokinkezelés csökkentette a sejtréteg ellenállását (15. ábra). A citokinekkel együtt adott $\alpha$-MSH peptidkezelés koncentrációfüggő hatást mutatott. A magasabb $\left(10^{-4}\right.$ és $\left.10^{-8} \mathrm{M}\right)$ koncentrációk védtek a citokinindukált ellenállás-csökkenés ellen, míg a kisebb $\left(10^{-12}\right.$ és $\left.10^{-16} \mathrm{M}\right)$ koncentrációknak nem volt ilyen hatása. További kísérleteinkben a Caco-2 bélepitélsejteken a $10^{-8} \mathrm{M}(10 \mathrm{nM})$ koncentrációjú $\alpha-M S H-k e z e l e ́ s t ~ a l k a l m a z t u k$. 


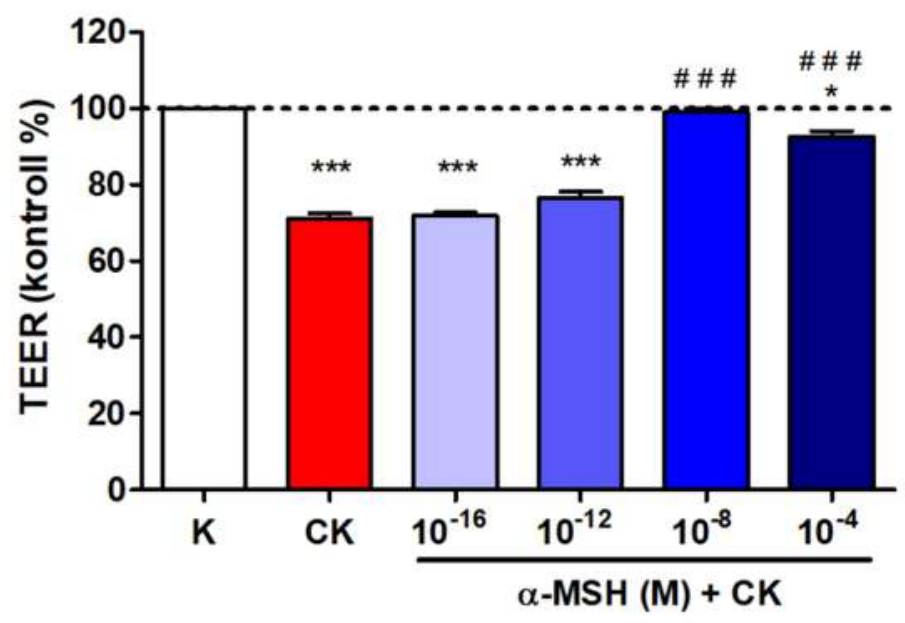

15. ábra. $\mathrm{Az} \alpha-\mathrm{MSH}$ hatása citokinkezelt Caco-2 bélepitélsejtréteg elektromos ellenállására (TEER). CK: $50 \mathrm{ng} / \mathrm{ml}$ TNF- $\alpha+25 \mathrm{ng} / \mathrm{ml} \mathrm{IL}-1 \beta$. Statisztika: ***, $\mathrm{P}<0,001$ a kontrollcsoporthoz képest; ${ }^{\# \#}, \mathrm{P}<0,001$ a citokinkezelt csoporthoz képest, egyutas ANOVA és Bonferroni-teszt.

\subsubsection{Permeabilitási vizsgálatok}

Az epitél- és endotélsejtrétegek integritásának, megfelelő müködésének mérésére alkalmas másik módszer a sejtrétegek permeabilitásának vizsgálata különböző méretü jelzőanyagokkal.

Alacsony permeabilitást mértünk mind a kis molekulatömegü fluoreszceinre, mind a nagy molekulatömegü albuminra a bélepitélsejtek egysejtrétegén (16A ábra). A citokinkezelés többszörösére emelte a jelzőmolekulák permeabilitását. Az $\alpha$-MSH peptid védőhatást mutatott a kis molekulatömegü fluoreszcein átjutásának fokozódásával szemben, míg az albumin esetében ez a hatás nem volt statisztikailag szignifikáns.

A vér-agy gát modellen hasonló változásokat mértünk. A patkány agyi endotélsejtek agyi pericitákkal és gliasejtekkel történő együttes tenyésztését követően a modellre jellemző alacsony permeabilitást mértünk a dextrán és albumin jelzőmolekulákra (16B ábra). A citokinkezelés ezen a tenyészetes modellen is megemelte a markerek átjutását. A $10^{-12} \mathrm{M}(1 \mathrm{pM}) \alpha-\mathrm{MSH}$-kezelés statisztikailag szignifikáns mértékben gátolta a citokinek gátmegnyitó hatását mind a kis molekulatömegü FITC-dextránra, mind a nagy molekulatömegű albuminra. A $10^{-11} \mathrm{M}\left(\begin{array}{lll}10 & \mathrm{pM}\end{array}\right)$ koncentrációjú $\alpha-\mathrm{MSH}$ pedig szignifikánsan erősítette a sejtréteget, és kivédte a nagyobb biomolekula albumin emelkedett permeabilitását. 
A

Caco-2

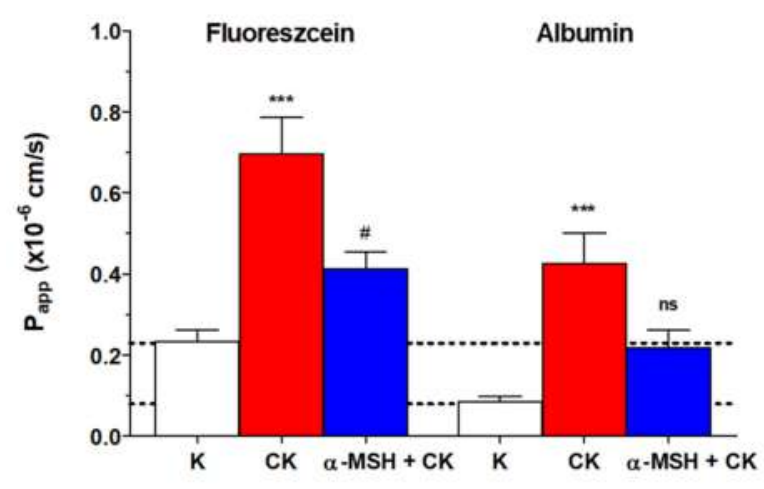

B

Patkány agyi endotélsejt

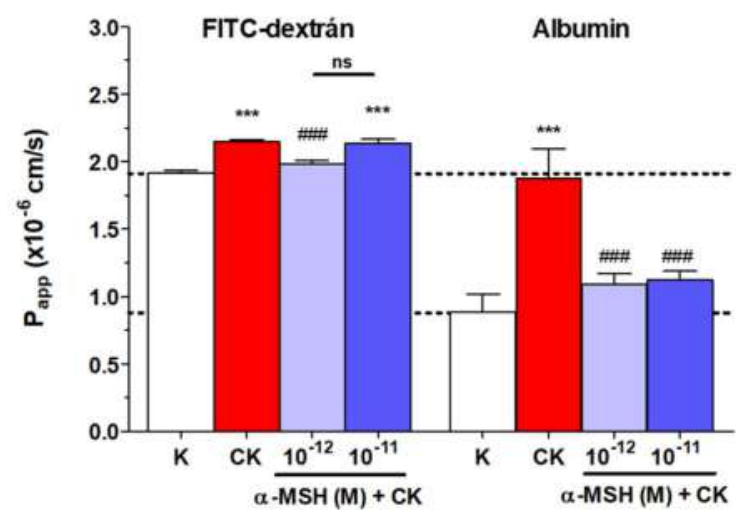

16. ábra. Az $\alpha-\mathrm{MSH}$ hatása citokinkezelt epitél- és agyi endotélsejt tenyészetek integritására különböző jelzőanyagok esetén. A) A Caco-2 bélepitélsejt-réteg fluoreszceinre és albuminra vonatkozó permeabilitása. CK: $50 \mathrm{ng} / \mathrm{ml}$ TNF- $\alpha+25 \mathrm{ng} / \mathrm{ml}$ IL-1 $\beta$. B) Patkány agyi endotélsejtréteg $4 \mathrm{kDa}$ FITC-dextránra és albuminra vonatkozó permeabilitása. CK: $10 \mathrm{ng} / \mathrm{ml}$ TNF$\alpha+10 \mathrm{ng} / \mathrm{ml}$ IL-1 $\beta$. Statisztika: ***, $\mathrm{P}<0,001$ a kontrollcsoportokhoz képest; ${ }^{\#}, \mathrm{P}<0,05,{ }^{\# \#}, \mathrm{P}<$ 0,001 a citokinkezelt csoportokhoz képest; ns, statisztikailag nem szignifikáns különbség a citokinkezelt csoporthoz képest, illetve a jelzett két csoport között, egyutas ANOVA és Bonferroniteszt.

\subsection{A citokinek és az $\alpha$-MSH hatása a reaktív oxigéngyökök termelődésére agyi endotélsejtekben}

A gyulladáskeltő citokinek hatására szignifikánsan megemelkedett a ROStermelődés patkány agyi endotélsejtekben a kezeletlen kontrollcsoporthoz képest (17.

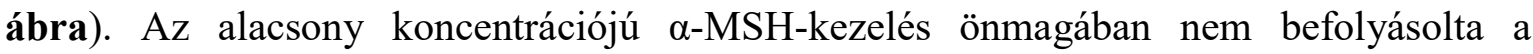
sejtekben a ROS termelődését, azonban a citokinekkel kezelt csoportban statisztikailag szignifikáns mértékben csökkentette a ROS mennyiségét. A hidrogén-peroxidot ROStermelödést fokozó referenciavegyületként használtuk a vizsgálatok során.

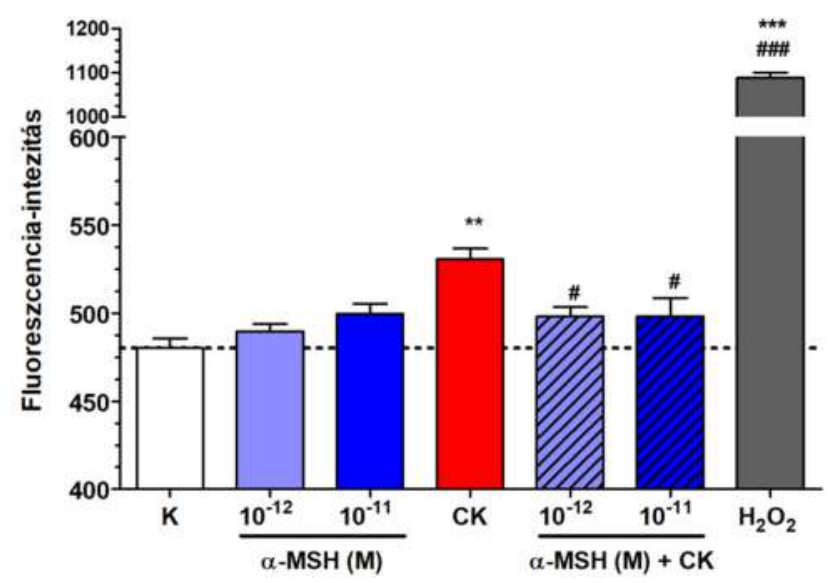

17. ábra. $\mathrm{Az} \alpha-\mathrm{MSH}$ hatása citokinkezelt tenyésztett patkány agyi endotélsejtekben reaktív oxigéngyök-termelődésére. CK: $10 \mathrm{ng} / \mathrm{ml} \mathrm{TNF}-\alpha+10 \mathrm{ng} / \mathrm{ml} \mathrm{IL}-1 \beta$. Statisztika: **, $\mathrm{P}<0,01$, ***, $\mathrm{P}<0,001$ a kontrollcsoporthoz képest; ${ }^{\#}, \mathrm{P}<0,05,{ }^{\# \#}, \mathrm{P}<0,001$ a citokinkezelt csoporthoz képest, egyutas ANOVA és Bonferroni-teszt. 
4.6. A citokinek és az $\alpha$-MSH hatása az epitél- és agyi endotélsejtek sejtkapcsoló fehérjéire

\subsubsection{Klaudin-4 és ZO-1 immunhisztokémia Caco-2 sejteken}

A bélepitélsejtek gátműködésének fizikai alapját a sejtkapcsoló fehérjék képezik. A klaudin-4 integráns sejtmembrán TJ fehérje és a citoplazmatikus ZO-1 linker fehérje a sejthatárokon folytonos, övszerü festődést mutatott (18. ábra). Citokinkezelés hatására az epitélsejtek között lyukak alakultak ki, a kapcsolófehérje-festődés felszakadozott és a ZO-1 immunfestés esetében citoplazmatikus átrendeződés volt megfigyelhető. Az $\alpha-\mathrm{MSH}$ peptidkezelés hatására a TJ fehérjék immunfestése a kontrollcsoporthoz hasonló mintázatot mutatott.
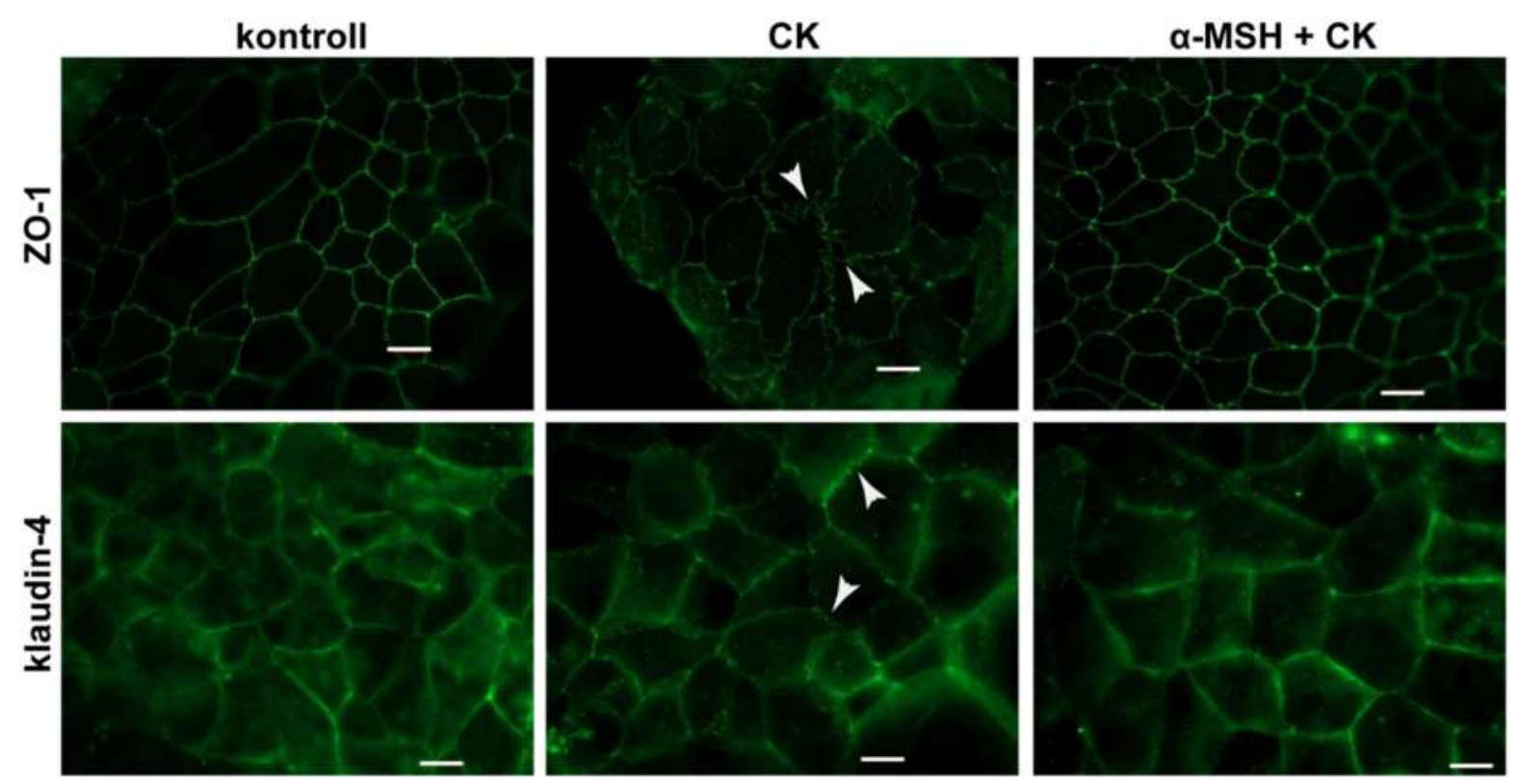

18. ábra. Az $\alpha$-MSH $\left(10^{-8} \mathrm{M}\right)$ hatása citokinkezelt humán Caco-2 epitélsejtvonal ZO-1 és klaudin4 immunfestésére. CK: $50 \mathrm{ng} / \mathrm{ml} \mathrm{TNF- \alpha}+25 \mathrm{ng} / \mathrm{ml} \mathrm{IL-1 \beta}$. Zöld: sejtkapcsoló fehérjék. Nyilak: a sejtkapcsoló fehérjék festődésének felszakadozása, megváltozása. Mérce: $10 \mu \mathrm{m}$.

\subsubsection{A klaudin-5 és $\beta$-katenin festődése patkány agyi endotélsejtekben}

A patkány agyi endotélsejtekben a szoros kapcsolatot képező klaudin-5 és az adherens kapcsolatok linker fehérjéje, a $\beta$-katenin festődése a sejthatárokon erős és folytonos volt (19A ábra), amelyet a citokinkezelés megváltoztatott: a sejtek között lyukakat, a sejten belül fehérje-átrendeződést figyeltünk meg. Az $\alpha$-MSH peptiddel történő együttes kezelés hatására a kapcsolófehérjék festődési mintázata a kontrollcsoporthoz hasonló volt. 
A
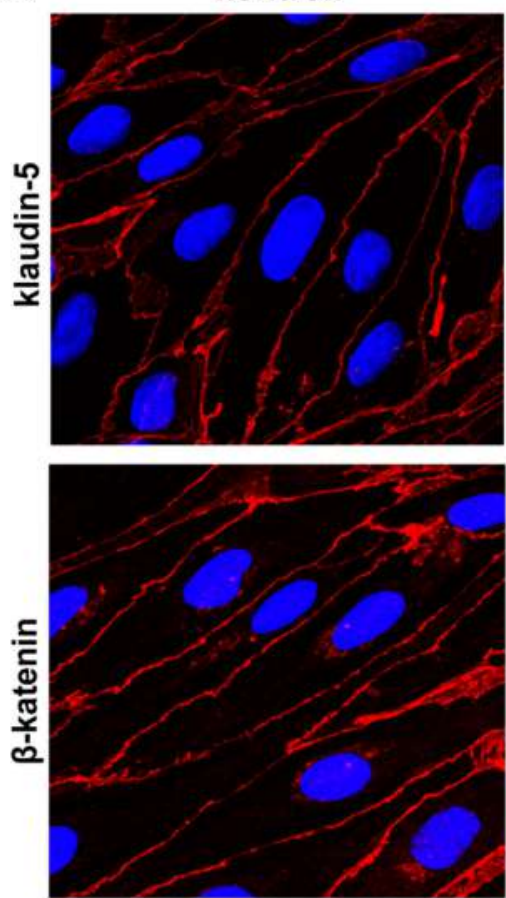

B

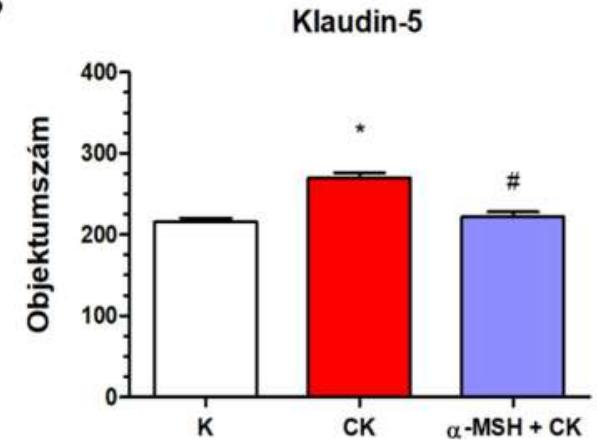

CK
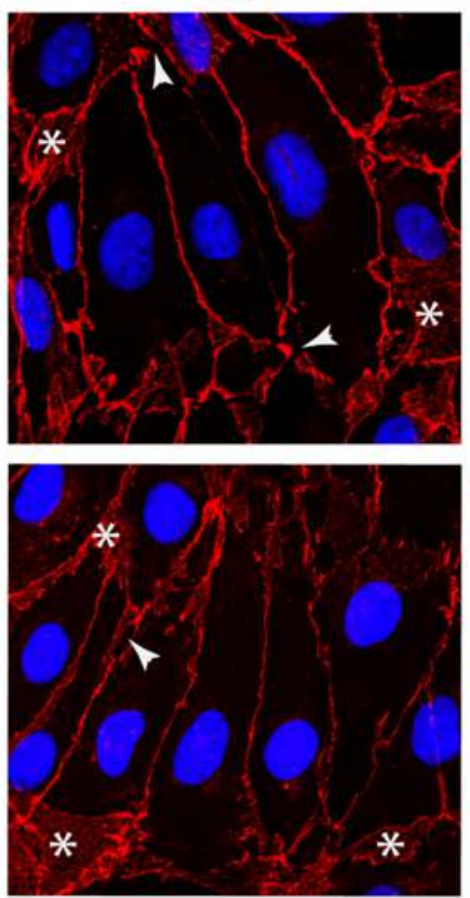

C
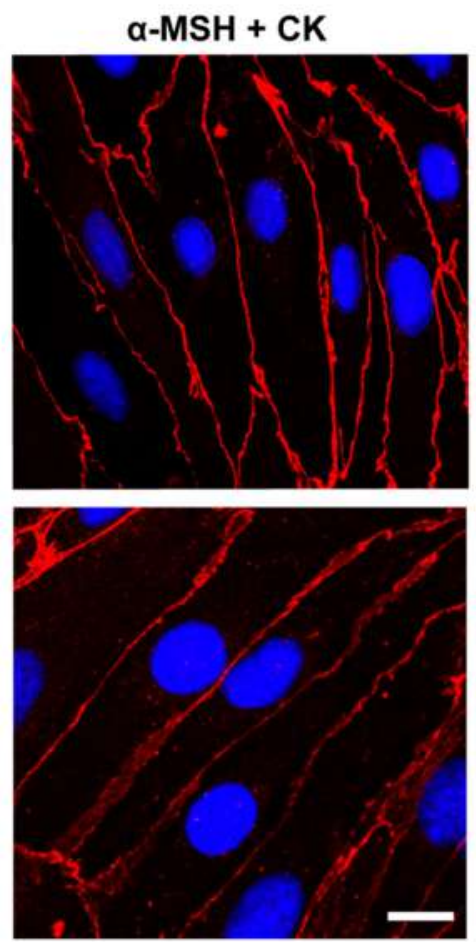

$\beta$-katenin

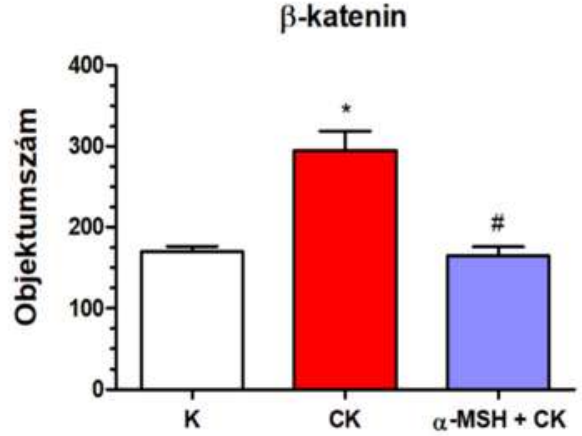

19. ábra. Az $\alpha$-MSH $\left(10^{-12} \mathrm{M}\right)$ hatása citokinkezelt patkány agyi endotélsejtek klaudin-5 és $\beta$ katenin immunfestésére. CK: $10 \mathrm{ng} / \mathrm{ml} \mathrm{TNF}-\alpha+10 \mathrm{ng} / \mathrm{ml}$ IL-1 $\beta$. A) Immunhisztokémia. Piros: sejtkapcsoló fehérjék; kék: sejtmag. Nyilak: a sejtkapcsoló fehérjék festődésének felszakadozása, megváltozása. Csillag: a sejtkapcsoló fehérjék sejten belüli átrendeződése. Mérce: $10 \mu \mathrm{m}$. B-C) Az objektumszámok szoftveres elemzése. Statisztika: *, $\mathrm{P}<0,05$ a kontrollcsoporthoz képest, ${ }^{\#}, \mathrm{P}<$ 0,05 a citokinkezelt csoporthoz képest, egyutas ANOVA és Bonferroni-teszt.

$\mathrm{Az}$ immunfestésben látott változásokat képkiértékelő program segítségével is számszerüsítettük mind a klaudin-5 (19B ábra), mind a $\beta$-katenin (19C ábra) esetében. A citokinkezelés hatására statisztikailag szignifikánsan megemelkedett konfokális mikroszkópos felvételeken az immunfestéssel jelölődő objektumok száma, míg $\alpha$-MSH hatására az objektumszám szignifikánsan csökkent a citokinkezelt csoportokhoz képest. 


\subsection{A citokinek és az $\alpha$-MSH hatása az NF-кB sejtmagi bejutására bélepitél- és agyi endotélsejtekben}

A sejtszintü gyulladásos válasz kimutatásának megbízható módja az NF-kB transzkripciós faktor p65 alegységének sejtmagba történő bejutásának nyomon követése.

Caco-2 bélepitélsejtekben a kontrollcsoportban a p65 alegység a citoplazmában volt megfigyelhető (20A ábra), és a sejtmagi és citoplazmatikus immunfestődés intenzitásának hányadosa alacsony volt (20B ábra). Citokinkezelés hatására a p65 alegység fluoreszcens jele intenzívebb lett a sejtmagban, ami az intenzitáshányados szignifikáns megemelkedését eredményezte. Az $\alpha$-MSH-kezelés statisztikailag szignifikánsan csökkentette az intenzitás-

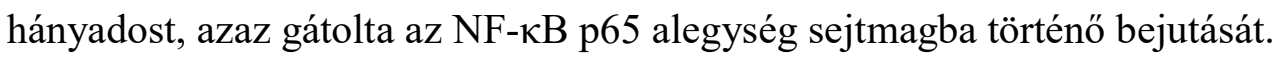

\section{A}
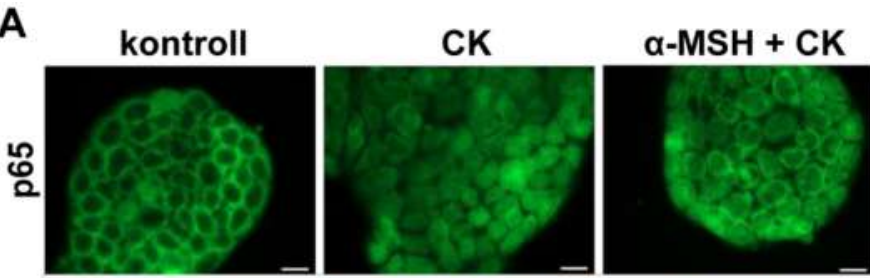

B
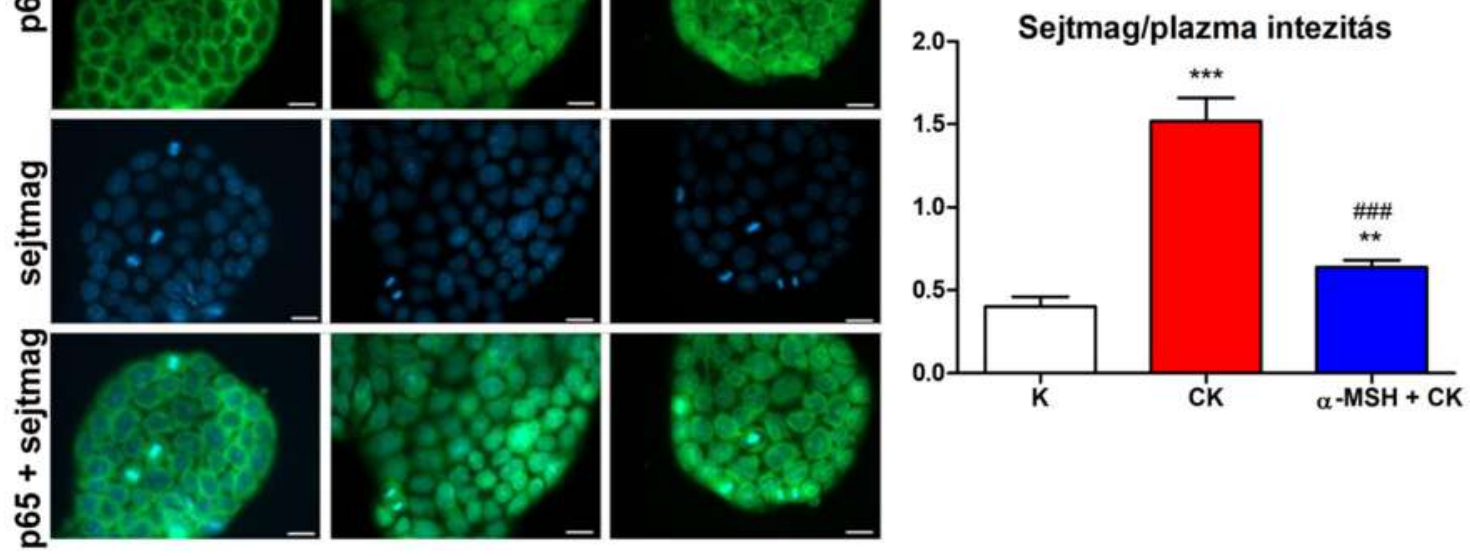

20. ábra. $\mathrm{Az} \alpha-\mathrm{MSH}\left(10^{-8} \mathrm{M}\right)$ hatása citokinkezelt humán Caco-2 epitélsejtekbenaz NF- $\mathrm{B}$ sejtmagba történő bejutására. CK: $50 \mathrm{ng} / \mathrm{ml} \mathrm{TNF- \alpha}+25 \mathrm{ng} / \mathrm{ml}$ IL-1 $\beta$. A) Immunhisztokémia. Zöld:

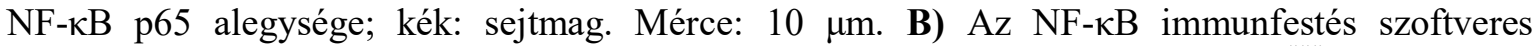
elemzése. Statisztika: **, $\mathrm{P}<0,01, * * *, \mathrm{P}<0,001$ a kontrollcsoporthoz képest; \#\# $, \mathrm{P}<0,001$ a citokinkezelt csoporthoz képest, egyutas ANOVA és Bonferroni-teszt.

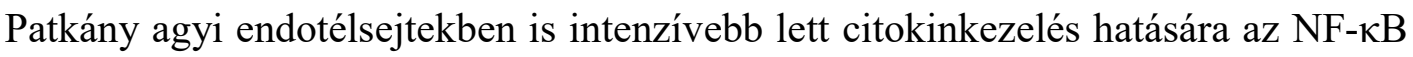
p65 alegységének sejtmagi festődése (21A ábra), amelyet számítógépes programmal végzett képkiértékeléssel is igazoltunk (21B ábra). Az endotélsejtek kezelése $\alpha$-MSH-val gátolta a p65 alegység sejtmagba történő bejutását, ezt jelezte a fehérje sejtmagi festődésének statisztikailag szignifikánsan csökkent intenzitása a citokinkezelt csoporthoz képest. 

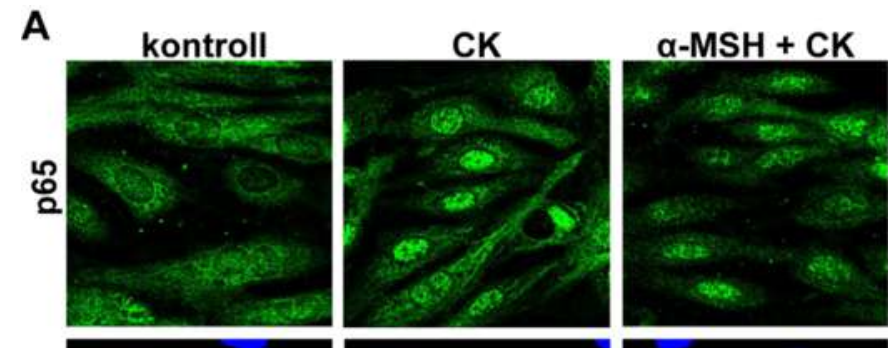

B
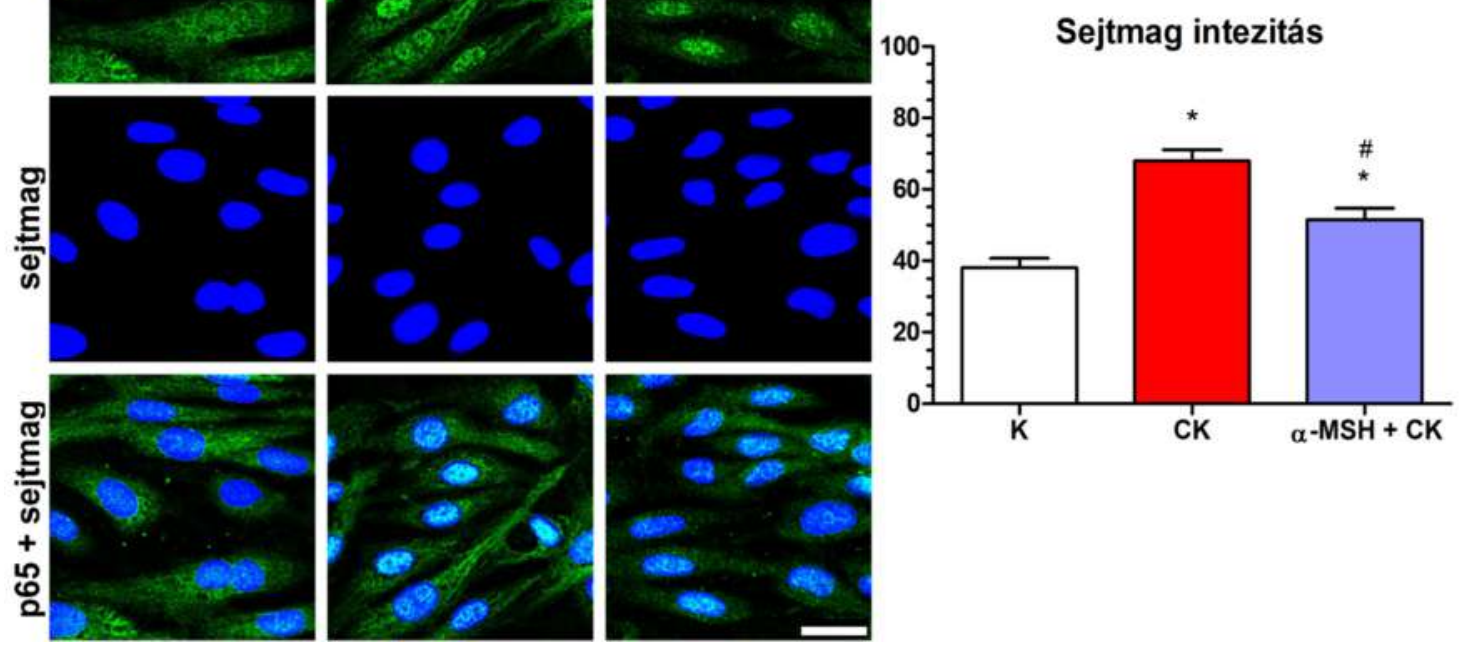

21. ábra. $\mathrm{Az} \alpha-\mathrm{MSH}\left(10^{-12} \mathrm{M}\right)$ hatása citokinkezelt patkány agyi endotélsejtekben az NF- $\mathrm{B}$ sejtmagba történő bejutására. CK: $10 \mathrm{ng} / \mathrm{ml}$ TNF- $\alpha+10 \mathrm{ng} / \mathrm{ml}$ IL-1 $\beta$. A) Immunhisztokémia. Zöld:

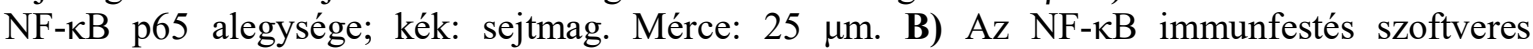
elemzése. Statisztika: *, P $<0,05$ a kontrollcsoporthoz képest; ${ }^{\#}, \mathrm{P}<0,05$ a citokinkezelt csoporthoz képest, egyutas ANOVA és Bonferroni-teszt. 


\section{Megbeszélés}

\subsection{Az MC1R fehérje jelenléte a bélhám és a vér-agy gát tenyészetes modelljein}

Az $\alpha$-MSH peptid szervezetben legelterjedtebb receptora az MC1R fehérje, melyet számos szövet- és sejttípuson leírtak már (Brzoska és mtsai, 2008; Catania és mtsai, 2010). A humán Caco-2 bélepitél-sejtvonalon először mutattuk ki a fehérje polarizált expresszióját (10. ábra). A sejtek apikális felszínén több immunfestéssel kimutatható receptort találtunk, mint a bazális felszínén. Eredményünk alátámasztja a peptid epitélsejtekre gyakorolt közvetlen hatásának hipotézisét, valamint megegyezik Maaser és munkatársainak adataival, akik az MC1R fehérje konstitutív kifejeződését írták le egér bélepitélsejteken (Maaser és mtsai, 2006).

Tenyésztett egér agyi endotélsejteken már bizonyították az $\alpha$-MSH hormon kötőhelyeinek jelenlétét (de Angelis és mtsai, 1995), de eddig nem azonosították a receptort ezen a sejttípuson. Eredményeink mind RNS- (11A ábra), mind fehérjeszinten igazolják az MC1R jelenlétét izolált patkány agyi mikroereken (11C ábra) és az ezekből tenyésztett agyi endotélsejteken (11B ábra). A bélepitélsejtekhez hasonlóan az MC1R agyi endotélsejteken kimutatott jelenléte alapján feltételeztük, hogy az $\alpha$-MSH peptid közvetlen hatást gyakorolhat erre a sejttípusra is.

\subsection{Az $\alpha$-MSH peptid önálló hatása agyi endotélsejtekre}

Élettani körülmények között az $\alpha$-MSH peptid koncentrációja a vérben igen alacsony, a humán vérplazmában 6 pM (Magnoni és mtsai, 2003), míg újszülött sertés vérplazmában 30 pM (Kovács és mtsai, 2001). A csoport korábbi állatkísérletes munkájában igazolta, hogy az $\alpha$-MSH szintje kóros körülmények között megváltozik: újszülöttkori sertésmodellen aszfixia és reperfúzió hatására a vérplazmában a hormon szintje megemelkedik, míg az agy-gerincvelői folyadékban lecsökken (Kovács és mtsai, 2001). A vérben található neuropeptidet az agyalapi mirigy termeli, míg az agy-gerincvelői folyadékban a peptid az idegrendszer sejtjeiből származik, ez magyarázza a neuropeptid mennyiségének eltérő szabályozását a két szöveti folyadéktérben (de Rotte és mtsai, 1980). A vér-agy gáton élettani körülmények között alacsony az átjutása az intravénásan beadott peptidnek (Wilson, 1988), ami az aktív transzport hiányára utal. Kórosan magas vagy farmakológiai koncentrációban azonban átjut az $\alpha-\mathrm{MSH}$ a vér-agy gáton (de Rotte és mtsai, 1980; Banks és Kastin, 1995). Kísérleteinkben ezek alapján széles koncentrációtartományban vizsgáltuk az $\alpha-M S H$ peptid önálló hatását sejtekre. 
A hormon hatását már tanulmányozták korábban tenyésztett humán bélepitélsejteken, ezért az $\alpha$-MSH sejtek életképességére gyakorolt hatását ezen a modellen nem vizsgáltuk. Tenyésztett agyi endotélsejtekre vonatkozóan azonban még nem állt rendelkezésre adat. Eredményeink alapján megállapítottuk, hogy az $\alpha$-MSH $(1 \mathrm{pM}-1 \mu \mathrm{M})$ nem befolyásolta az endotélsejtek növekedését, a sejtréteg integritását (12A ábra), és nem okozott sejtkárosodást (12B ábra).

\subsection{Az $\alpha-M S H$ védőhatása citokinekkel kiváltott károsodással szemben}

\subsubsection{Bélepitélsejt modell}

A két legfontosabb gyulladáskeltő citokin, a TNF- $\alpha$ és az IL-1 $\beta$ kombinációjával történő kezelés hatására a humán Caco-2 epitélsejtek közötti paracelluláris útvonal megnyílt. A bélepitél-sejtréteg két oldala között mérhető elektromos ellenállás leesett citokinkezelés hatására (15. ábra), míg a sejtréteg áteresztőképessége jelzőmolekulákra megemelkedett (16A ábra). Eredményeinket alátámasztják korábbi kutatási adatok, amelyek már bizonyították a TNF- $\alpha$ és az IL-1 $\beta$ citokinek Caco-2 sejtekre gyakorolt gátmegnyitó hatását (Ramadan és mtsai, 2016; Al-Sadi és mtsai, 2012).

Az $\alpha$-MSH hormon $10^{-8} \mathrm{M}(10 \mathrm{nM})$ és $10^{-4} \mathrm{M}(100 \mu \mathrm{M})$ koncentrációban kivédte a citokinek által kiváltott ellenállás-csökkenést Caco-2 modellen. Citokinkezelés hatására ugyanis több nátriumion jutott át a sejtek közötti megnyílt kapcsolatokon, ezáltal csökkentve a két oldal közötti ellenállást, míg ez a hatás az $\alpha$-MSH hormonnak köszönhetően mérséklődött. Más típusú sejteken, például humán dermális hajszálér-eredetü endotél-sejtvonalon (Kalden és mtsai, 1999) és humán vesecsatorna epitélsejtvonalon (Bijuklic és mtsai, 2007) is hasonló koncentrációjú $\alpha$-MSH peptidkezelések bizonyultak hatékonynak. TEER kísérletünkben az $\alpha$-MSH védőhatása nem volt egyenesen arányos a növekvő peptidkoncentrációval. Ez a megfigyelésünk összhangban áll irodalmi adatokkal, amelyek alapján az $\alpha$-MSH hatását, hasonlóan más peptidhormonokéhoz, harang alakú hatásgörbe jellemezte (Joosten és mtsai, 1996).

A humán bélepitélium modellen citokinkezelés hatására megnőtt a kis molekulatömegü fluoreszcein és a nagy molekulatömegü albumin átjutása (16A ábra). A TEER kísérletben leghatásosabbnak bizonyult koncentrációban adva a neuropeptidet a jelzőanyagok permeabilitása mérséklődött, hasonlóan az ionok átjutására vonatkozó TEER eredményekhez.

A TEER és permeabilitási adatok arra utaltak, hogy a gyulladáskeltő citokinek hatására a sejtek közötti szoros kapcsolatok megnyíltak. Ennek morfológiai igazolására a 
sejtkapcsoló fehérjék festődési mintázatát is megvizsgáltuk. A Caco-2 epitélsejteken mind a klaudin-4 integráns TJ membránfehérje, mind a ZO-1 linkerfehérje immunfestése citokinkezelés hatására megváltozott: a sejthatárokon a festődés felszakadozását, illetve a sejtmembránból a citoplazmába való átrendeződését figyeltük meg (18. ábra). Az $\alpha-\mathrm{MSH}$ peptid védőhatását figyeltük meg az epitélsejtek közötti kapcsolatok morfológiájára, a permeabilitási eredményekhez hasonlóan. A csoportunk egy korábbi munkájában szintén kimutatta a sejtkapcsolatok morfológiai változását a paracelluláris útvonal megnyílásával párhuzamosan TJ-specifikus peptidek alkalmazását követően (Bocsik és mtsai, 2016). Megfigyelésünket alátámasztja, hogy más tudományos közlemények is leírták már a klaudin-4 fehérje gátfunkcióban betöltött szerepét különböző epitélsejt-típusokon, illetve azt, hogy a gyulladáskeltő citokinek hatására megnő a mobilis klaudin-4 mennyisége Caco2 sejtek szoros kapcsolataiban, ami összefügg a barrierfunkció romlásával (Wang és mtsai, 2009; Capaldo és mtsai, 2014). A kísérletes adatok jelentőségét megerősíti, hogy fekélyes vastagbélgyulladásban szenvedő betegek biopsziából származó bélmintáiban is a klaudin-4 TJ fehérje kifejeződésének csökkenése volt kimutatható (Oshima és mtsai, 2008).

\subsubsection{Tenyészetes vér-agy gát modell}

Az epitélsejtes kísérletekhez hasonlóan a vér-agy gát tenyészetes modelljén is a TNF- $\alpha$ és IL-1 $\beta$ citokinek kombinációját használtuk a gyulladásos folyamatok modellezésére. Megállapítottuk, hogy az agyi endotélsejtek érzékenyek voltak a citokinkezelésre (13. ábra). Már az alacsonyabb citokinkoncentráció (10 ng/ml TNF- $\alpha$ és $10 \mathrm{ng} / \mathrm{ml} \mathrm{IL-1 \beta )}$ is hasonló mértékben csökkentette a sejtrétegek impedanciáját, mint a humán Caco-2 sejteken használt kombináció (50 ng/ml TNF- $\alpha$ és 25 ng/ml IL-1 $\beta$ ).

A gyulladáskeltő citokinek megemelik a vér-agy gát tenyészetes modelljeinek áteresztőképességét (Deli és mtsai, 1995; Didier és mtsai, 2003; Lopez-Ramirez és mtsai, 2012). Az irodalmi adatokhoz és a Caco-2 sejteken kapott eredményekhez hasonlóan a TNF- $\alpha$ és az IL-1 $\beta$ együttes adása csökkentette a sejtréteg impedanciáját (14. ábra) és megemelte a jelzőmolekulák permeabilitását (16B ábra), ami az agyi endotélsejtek gátmüködésének sérülésére utaltak. Mindezek a hatások azonban kis koncentrációjú $\alpha$ MSH-kezelésnek köszönhetően visszafordíthatóknak bizonyultak, megemelkedett az impedancia és mérséklödött mind a kis molekulatömegü dextrán és a nagy molekulatömegü albumin átjutása is a vér-agy gát modelljén. Az $\alpha$-MSH peptid fiziológiás koncentrációban adva nem befolyásolta az agyi endotélsejt-rétegek integritását (12A ábra). Ezt a megfigyelésünket korábbi munkák is alátámasztják: kis koncentrációjú $\alpha$ - 
MSH-kezelés nem fokozta a vér-agy gát áteresztőképességét sem albuminra (Sankar és mtsai, 1981), sem kisméretü anionokra (Kastin és Fabre, 1982).

A permeabilitási kísérletben megfigyelt gátmegnyílást az agyi endotélsejtek közötti kapcsoló fehérjék, mint az endotélsejtspecifikus klaudin-5 és a linkerfehérje $\beta$-katenin, festődése is megerősítette. A gyulladásos citokinekkel történő kezelés a sejthatárokon a festődés felszakadozását, valamint a fehérjék citoplazmatikus átrendeződését eredményezte (19A ábra). A kapcsoló fehérjék festődésének megváltozása a minták megemelkedett objektumszámában is tükröződött (19B-C ábra). Két független munka is igazolta a közvetlen kapcsolatot a gyulladáskeltő citokinek és az agyi endotélsejtek szoros kapcsolatainak megnyílása között. A klaudin-5 gén promóterében a gyulladásos folyamatokban aktiválódó NF- $\mathrm{B}$ B válaszelemeket azonosítottak, melyek TNF- $\alpha$-kezelés hatására mérsékelték a gén aktivitását és transzkripcióját agyi és miokardiális endotélsejtekben (Burek és Förster, 2009). A TNF- $\alpha$ a klaudin-5 génaktivitást az NF-kB jelátviteli úton keresztül gátolta egér agyi endotélsejtekben is (Aslam és mtsai, 2012). A gyulladáskeltő citokinek sejtkapcsolatok morfológiájára kifejtett hatása az $\alpha$-MSH peptiddel történő kezelés hatására mérséklődött, a sejthatárok szerkezete helyreállt, a citoplazmában a festődés csökkent, ami az objektumszámok mennyiségi analízisében is megmutatkozott (19A-C ábra).

\subsection{Az $\alpha$-MSH védőhatásának lehetséges mechanizmusai}

\subsubsection{Bélepitélsejt modell}

A gyulladáskeltő citokinek bélepitélsejtek gátmüködésére kifejtett hatásának mechanizmusát már részleteiben leírták, és ezt eredményeink is alátámasztották (22. ábra). Korábbi kutatások igazolták, hogy Caco-2 bélepitélsejtekben a TNF- $\alpha$-kezelés által kiváltott fokozott TJ-permeabilitás a ZO-1 kapcsoló fehérje kifejeződésének csökkenésével és a sejtkapcsolatokban való lokalizációjának megváltozásával jár, amit az NF- $\mathrm{B}$ transzkripciós faktor aktivációja közvetít (Al-Sadi és mtsai, 2013). Az IL-1 $\beta$ citokinnel történő kezelés szintén aktiválja az NF-kB útvonalat Caco-2 sejtekben, ami fokozott permeabilitáshoz vezet (Al-Sadi és mtsai, 2012). Citokinkezelés hatására ugyanis a

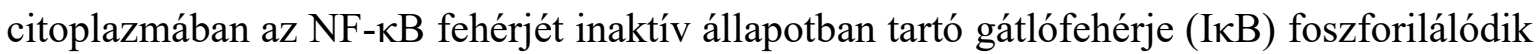
és konformációváltozást követően leválik a transzkripciós faktorról, mely így mindkét alegységével (p50 és p65) a sejtmagba kerül és különböző promóterekhez kötődve szabályozza az epitélsejt génkifejeződési mintázatát. TNF- $\alpha$ és IL-1 $\beta$ együttes kezelés hatására kísérleteinkben is megemelkedett az NF-kB fehérje p65 alegységének sejtmagi 
jelenléte, amit az $\alpha$-MSH peptid kivédett (22. ábra). A citokinek permeabilitást fokozó hatása mérséklődött az $\alpha$-MSH-kezelésnek köszönhetően Caco-2 bélepitélsejtekben párhuzamosan a szoros kapcsolatok morfológiájának visszaállásával.

Epitélsejt
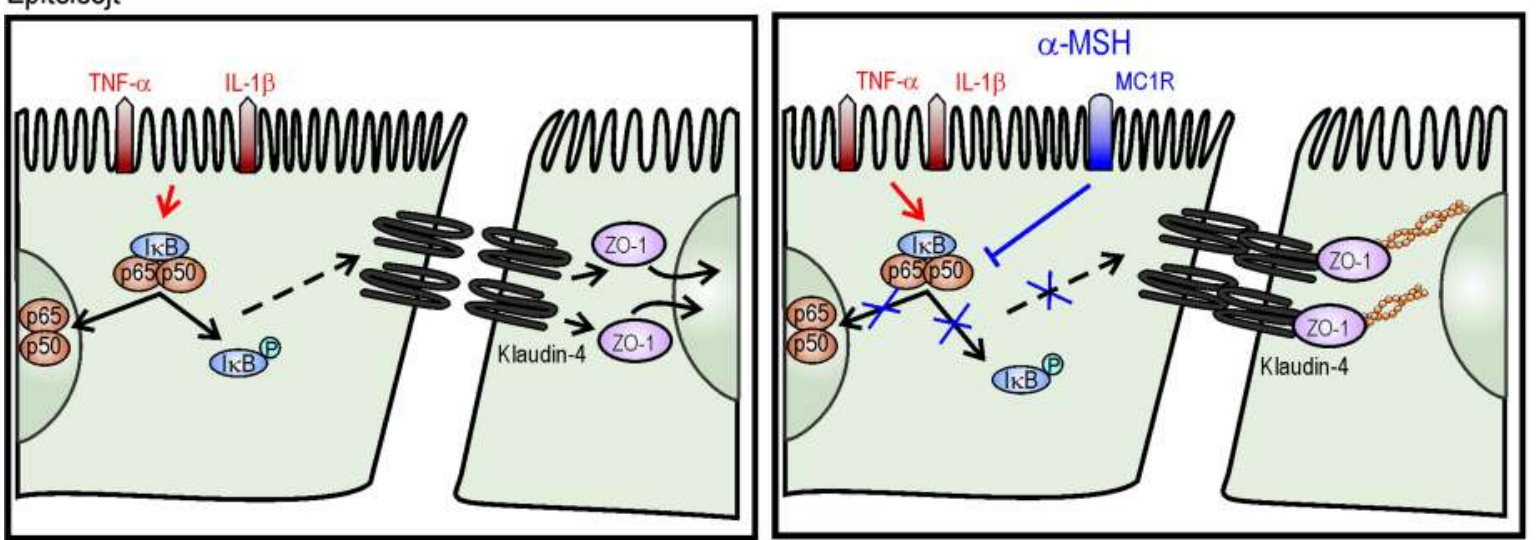

22. ábra. Az $\alpha$-MSH gyulladáscsökkentő hatása bélepitélsejtekben: az NF- $\mathrm{kB}$ transzkripciós faktor aktiválódásának gátlása, a sejtkapcsoló fehérjék kifejeződésének és lokalizációjának elősegítése, ezzel a fokozott permeabilitás csökkentése.

Eredményeink megerősítik, hogy az $\alpha$-MSH peptid hatásos gyulladáscsökkentő

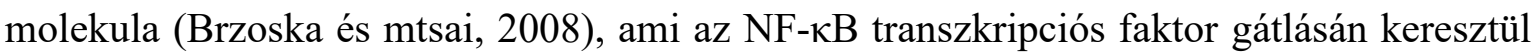
fejti ki hatását. Ezt igazolják azok a tudományos közlemények is, melyekben az NF-кB útvonal gátlását találták kulcsfontosságúnak az $\alpha$-MSH védőhatásában oxidatív stressz által okozott bélepitélsejt károsodásban (Zou és mtsai, 2004), illetve iszkémia-reperfúzió következtében fellépő bélsérülésben patkányokban (Hassoun és mtsai, 2002; Zou és mtsai, 2003).

\subsubsection{Tenyészetes vér-agy gát modell}

A legtöbb gyulladásos folyamat velejárója a reaktív oxigéngyökök termelődésének fokozódása és az általuk okozott oxidatív stressz. Az oxidatív stressz az egyik fó mechanizmusa a gyulladások okozta idegsejt-károsodásnak is (Sochocka és mtsai, 2017). A termelődő ROS központi szerepet játszik a citokinek, vagy a $\beta$-amiloid peptid által kiváltott vér-agy gát áteresztőképesség-fokozódásban (Rochfort és Cummins, 2015; Veszelka és mtsai, 2013). A citokinek okozta megemelkedett ROS-termelődést mi is kimutattuk, és ez a hatás visszafordíthatónak bizonyult $\alpha$-MSH-kezelést követően (17. ábra). Az $\alpha$-MSH peptid szuperoxidgyökökre és prosztaglandinokra kifejtett gátlóhatását már számos sejttípuson bizonyították (Brzoska és mtsai, 2008), de agyi endotélsejteken 
mindezidáig még nem. Adataink alapján az $\alpha$-MSH gyulladáscsökkentő hatása agyi endotélsejteken részben a reaktív oxigéngyökök termelődésének gátlásán keresztül érvényesülhet (23. ábra). Habár a hormonról magáról nem mutatták még ki gyökfogó tulajdonságát, de számos tanulmány bizonyítja, hogy a sejtek redoxegyensúlyát

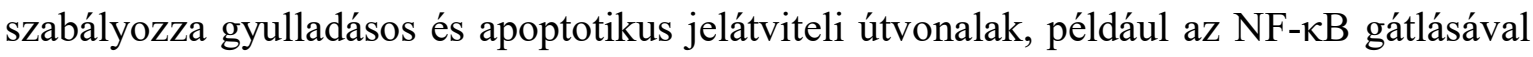
(Brzoska és mtsai, 2008; Zou és mtsai, 2004).
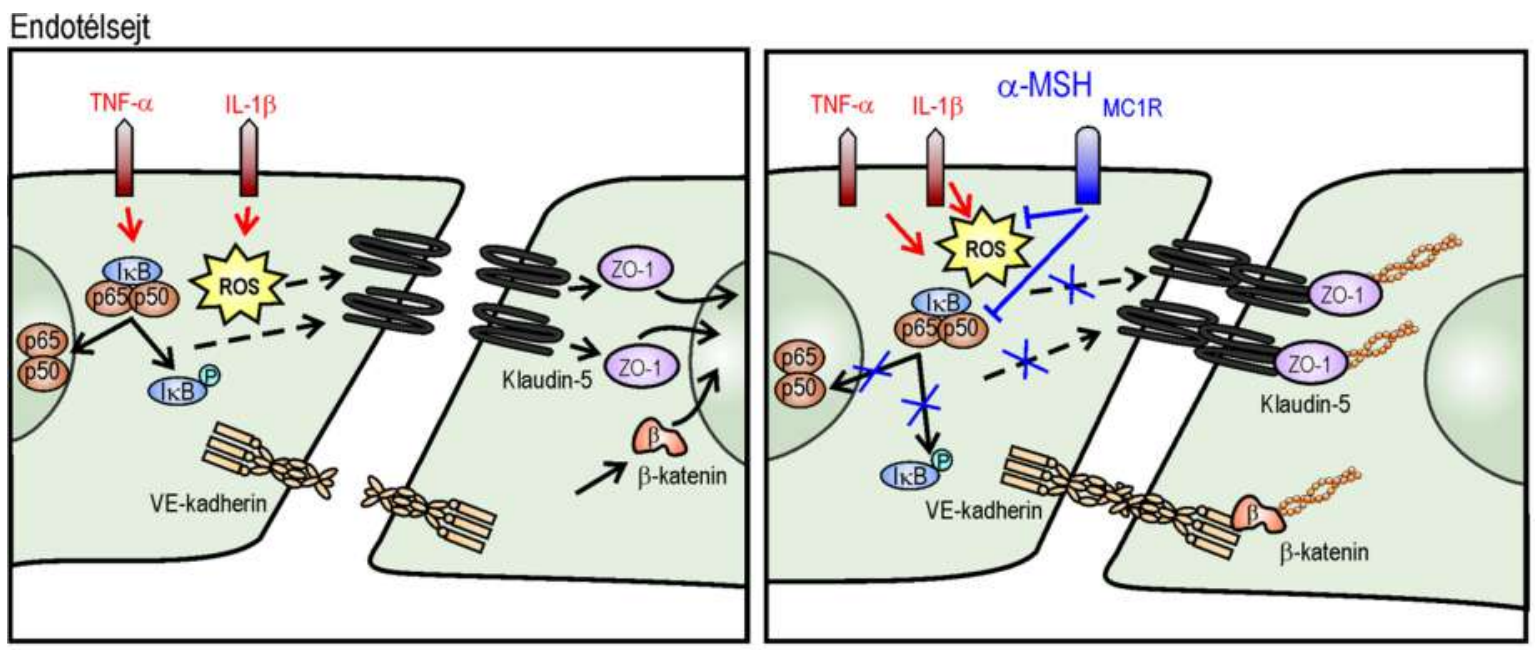

23. ábra. Az $\alpha$-MSH gyulladáscsökkentő hatása agyi endotélsejtekben: a ROS-termelődés, és az $\mathrm{NF}-\kappa \mathrm{B}$ transzkripciós faktor aktiválódásának gátlása, a sejtkapcsoló fehérjék kifejeződésének és lokalizációjának elősegítése, ezzel a fokozott permeabilitás csökkentése.

A kanonikus NF- $\kappa$ B jelátviteli útvonalat mind a TNF- $\alpha$, mind az IL-1 $\beta$ aktiválni tudja agyi endotélsejtekben, ami olyan gének átírásához vezet, mint a ciklooxigenáz-2, a nitrogén-monoxid szintázok, a gyulladásos citokinek és a mátrix metalloproteinázok (Pires és mtsai, 2018), melyek közvetlenül részt vesznek a vér-agy gát müködésének

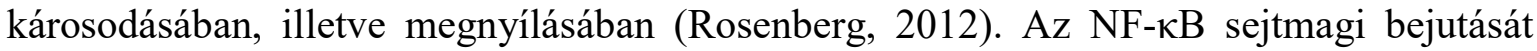
már leírták perifériás endotélsejtekben TNF- $\alpha$ vagy IL-1 $\beta$ kezelések után (Makó és mtsai, 2010), akárcsak agyi endotélsejtek gyulladásos útvonalában (Lee és mtsai, 2001). Eredményeink igazolták, hogy citokinkezelés hatására az NF- $\kappa \mathrm{B}$ fehérje bejutott az agyi endotélsejtekben a sejtmagba, és ezt a hatást az $\alpha-\mathrm{MSH}$ gátolta (23. ábra), a bélepitélsejteken kapott eredményeinkhez hasonlóan.

Mivel a TNF- $\alpha$-kezelt agyi endotélsejtekben az NF- $\mathrm{B}$ jelátviteli útvonal közvetlenül csökkenti a klaudin-5 kifejeződését (Burek és Förster, 2009; Aslam és mtsai, 2012), az $\alpha$-MSH peptid védőhatását, legalábbis részben, ezen a jelátviteli útvonalon 


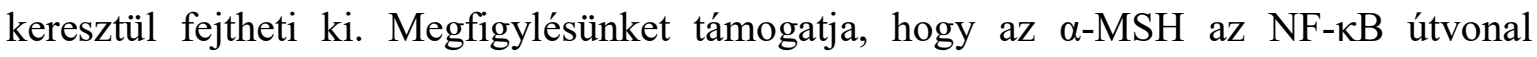
gátlásán keresztül csökkentette a sejtadhéziós molekulák kifejeződését citokinkezelt perifériás endotélsejtekben (Kalden és mtsai, 1999).

\subsection{Az $\alpha$-MSH lehetséges terápiás alkalmazása}

Az utóbbi 60 évben intenzív kutatások zajlanak enzimatikus hatásoknak ellenálló melanocita stimuláló hormonok fejlesztése céljából. Az $\alpha-M S H$ peptid féléletideje a vérben és szövetekben az aktív proteázoknak köszönhetően rövid, de a peptid módosítása, például az acetilálás, növeli a hormon stabilitását (Ericson és mtsai, 2017). A melanocita stimuláló hormonokban közös szekvencia (His-Phe-Arg-Trp, HFRW) módosított változata erős melaninszintézist serkentő hatással bírt, míg az N- és az C-terminális peptidrészleteknek nem volt ilyen hatásuk. Habár a C-terminális tripeptid (Lys-Pro-Val, KPV) nem váltott ki pigmenttermelés a melanocitákban, de hatékony gyulladáscsökkentő molekulának bizonyult több sejtes és állatkísérletben is (Brzoska és mtsai, 2008).

Az emberi szervezetben termelődő melanokortinokon felül több, mint 15 szintetikus peptiddel folytatnak vizsgálatokat, és már többnek bizonyították gyulladáscsökkentő hatását (Ahmed és mtsai, 2013). Az Egyesült Államokban a klinikai gyakorlat része a köszvény ACTH-val történő kezelése, különösen olyan betegeknél, ahol a nem szteroid gyulladáscsökkentők nem javasoltak. Vizsgálják továbbá az ACTH hatását vesegyulladásokban, szklerózis multiplexben és reumatikus eredetü megbetegedésekben. Klinikai vizsgálatok folynak egy $\alpha$-MSH-származék, az afamelanotid gyulladáscsökkentő hatását kihasználva naperedetü csalán-kiütés, akne vagy éppen porfíria egyes változatának kezelésében (Ahmed és mtsai, 2013). Egy másik szintetikus peptidet, az AP214-et szívmütéten átesett emberek esetében a lehetséges vesekárosodás megelőzésére használják.

A legtöbb szintetikus peptid azonban számos melanokortin receptorhoz képes kötődni, azokon jelátviteli útvonalat beindítani, ezért nem kívánt mellékhatások jelentkezhetnek. Az MC1R receptort aktiválva a bőr pigmentációja, szélsőséges esetben melanóma alakulhat ki. Az MC3R, az MC4R és az MC5R receptorokhoz kötődve magas vérnyomást és viselkedészavart okozhatnak a melanokortinok (Ahmed és mtsai, 2013). Ezért fontos, hogy a proteázokkal szembeni stabilitása mellett minél inkább receptorszelektív legyen az adott peptid. Az $\alpha$-MSH-ból származtatott két tripeptid is hatékony gyulladáscsökkentőnek bizonyul kísérletekben. Amíg azonban a KPT szintetikus peptid mindegyik melanokortin receptorhoz kötődik, addig a már említett KPV csak az MC1R fehérjéhez. 
Mindezek alátámasztják az $\alpha$-MSH peptid gyulladásokban jelentkező védőhatásának további preklinikai és akár klinikai vizsgálatát, azonban a lehetséges terápiás alkalmazáshoz receptorszelektív és stabilabb szintetikus $\alpha$-MSH analógokra van szükség.

\section{6. Összegzés}

A biológiai gátrendszerek védelme elsődleges fontosságú az élő szervezetek szempontjából. Ezek sérülése figyelhető meg különböző gyulladásos folyamatok során is, ahol a felszabaduló gyulladáskeltő citokinek, mint a TNF- $\alpha$ és az IL-1 $\beta$, a barrierek sérülését okozzák. Mind az intesztinális, mind a központi idegrendszeri sérülések során leírták e két citokin kulcsszerepét, hogy hozzájárulnak a gátrendszerek sejtjeit egymáshoz füző TJ fehérjék átrendeződéséhez, ezáltal csökkentik a barrier ellenállását és növelik annak áteresztőképességét. A gyulladáskeltő citokinek biológiai gátakat károsító hatásában az oxidatív stressz is kiváltó tényező.

Az $\alpha$-MSH peptid gyulladásos folyamatokkal szembeni védőhatását számos állatkísérletes modellen és sejttípusban leírták korábban, de Caco-2 bélepitélsejteken és agyi endotélsejteken eddig nem állt rendelkezésre adat. Munkánk során bizonyítottuk, hogy az $\alpha$-MSH elsődleges receptorának tekinthető MC1R fehérje mind a humán Caco-2 bélepitélsejtvonalon, mind patkány agyi endotélsejteken kifejeződik, és az utóbbi sejtekre széles koncentrációtartományban sincs károsító hatása. Gyulladásos körülmények között kimutattuk, hogy az $\alpha$-MSH peptid mind a bélepitélium, mind a vér-agy gát tenyészetes modelljein védőhatású. $\mathrm{Az} \alpha-\mathrm{MSH}$ az $\mathrm{NF}-\kappa \mathrm{B}$ jelátviteli útvonal gátlásán keresztül csökkentette agyi endotélsejtekben az oxigéngyökök termelödését, és mindkét modellen mérsékelte a citokinek okozta permeabilitásfokozódást, és az ezzel párhuzamosan kialakuló változást a sejtkapcsoló fehérjék immunfestődési mintázatában. Az általunk vizsgált két biológiai gátrendszer tenyészetes modelljein tehát az $\alpha-\mathrm{MSH}$ peptid, legalábbis részben, az NF-kB fehérje sejtmagba történő bejutásának gátlásával biztosítja a sejtkapcsoló fehérjék kifejeződésének és a barrierek megfelelő működésének visszaállását citokinek okozta károsodásban.

Mindezek az eredmények megerősítik az $\alpha$-MSH hormon jótékony hatását a biológiai barrierek védelmében. 


\section{Köszönetnyilvánítás}

Mindenek előtt hálás köszönettel tartozom témavezetőimnek, Dr. Deli Máriának és Dr. Tubak Vilmosnak a munkám során nyújtott szakmai irányításért és szüntelen támogatásért.

Szeretném megköszönni együttmüködő partnereinknek, akik lehetővé tették a közös cikkek publikálását. Hálás köszönet Dr. Vecsernyés Miklósnak és a Debreceni Egyetem Gyógyszertechnológiai Intézet munkatársainak az együtt végzett közös munkáért és szakmai támogatásért.

Köszönetet mondok a Biológiai Barrierek Kutatócsoport valamennyi jelenlegi és egykori munkatársainak, Dr. Kürtiné Bocsik Alexandrának, Dr. Hoyk Zsófiának, Dr. Walter Fruzsinának, Barna Lillának, Vigh Juditnak, Dr. Veszelka Szilviának, Mészáros Máriának, Gróf Ilonának, Ana Raquel Pato Santa Mariának, Dr. Sántha Petrának, Dr. Kiss Lórándnak, Dr. Tóth Andreának, valamint Sütöri Balázs és Bálint Armand hallgatóinknak a baráti légkörért és a rengeteg szakmai támogatásért, segítségért.

Külön köszönet illeti a Creative Labor Kft. munkatársait, Váczi Balázst, Kovács Ritát, Kereső Juditot és Simon Ferencné Anikót barátságukért és az egyetemi tanulmányaim során nyúj tott támogatásukért.

Köszönöm Dr. Ormos Pálnak és Dr. Nagy Ferencnek, az MTA SZBK főigazgatóinak, Dr. Zimányi Lászlónak, a Biofizikai Intézet igazgatójának és Dr. Siklós Lászlónak, a Molekuláris Neurobiológiai Kutatóegység vezetőjének, hogy lehetővé tették az intézetben való munkámat. Köszönöm a kutatóegység, a Biofizikai Intézet és az egész kutatóközpont minden munkatársának támogatását. Külön szeretném megköszönni Tóth Sándorné Marikának, Dr. Ferenc Györgyinek, Kincses Andrásnak, Melczer Zsófiának, Verebes Beátának, Dr. Vizler Csabának, Jósvay Katalinnak, Dr. Marton Annamáriának és Buhala Andreának barátságukat és támogatásukat.

Hálás vagyok továbbá Dr. Ábrahám Csongor páratlan szakmai támogatásáért és odafigyeléséért.

Kimondhatatlanul hálás vagyok barátaimnak az egyetemi és a doktori éveim alatt adott biztatásukért, szeretetükért, hogy hittek bennem és támogattak.

Végezetül mélységes hálát érzek Nagymamám és Édesanyám szerető iránymutatásáért, Apukám, Öcsém, Nagybátyám, Felesége és Lánya feltétlen támogatásáért és szeretetéért.

Jelen kutatás és doktori értekezés megvalósításához az EFOP-3.6.1-16-2016-00008 számú pályázat nyújtott támogatást. 


\section{Irodalomjegyzék}

Abbott NJ, Patabendige AA, Dolman DE, Yusof SR, Begley DJ. Structure and function of the blood-brain barrier. Neurobiol Dis. 2010 Jan;37(1):13-25.

Abbott NJ, Rönnbäck L, Hansson E. Astrocyte-endothelial interactions at the blood-brain barrier. Nat Rev Neurosci. 2006 Jan;7(1):41-53.

Abraham CS, Deli MA, Joo F, Megyeri P, Torpier G. Intracarotid tumor necrosis factoralpha administration increases the blood-brain barrier permeability in cerebral cortex of the newborn pig: quantitative aspects of double-labelling studies and confocal laser scanning analysis. Neurosci Lett. 1996 Apr 19;208(2):85-8.

Ahmed TJ, Montero-Melendez T, Perretti M, Pitzalis C. Curbing Inflammation through Endogenous Pathways: Focus on Melanocortin Peptides. Int J Inflam. 2013;2013:985815.

Al-Asmakh M, Hedin L. Microbiota and the control of blood-tissue barriers. Tissue Barriers. 2015 May 29;3(3):e1039691.

Al-Sadi R, Guo S, Dokladny K, Smith MA, Ye D, Kaza A, Watterson DM, Ma TY. Mechanism of interleukin-1 $\beta$ induced-increase in mouse intestinal permeability in vivo. J Interferon Cytokine Res. 2012 Oct;32(10):474-84.

Al-Sadi R, Guo S, Ye D, Ma TY. TNF- $\alpha$ modulation of intestinal epithelial tight junction barrier is regulated by ERK1/2 activation of Elk-1. Am J Pathol. 2013;183(6):187184.

Al-Sadi R, Ye D, Said HM, Ma TY. IL-1beta-induced increase in intestinal epithelial tight junction permeability is mediated by MEKK-1 activation of canonical NF- $\mathrm{KB}$ pathway. Am J Pathol. 2010;177(5):2310-22.

Aslam M, Ahmad N, Srivastava R, Hemmer B. TNF-alpha induced NFkB signaling and p65 (RelA) overexpression repress Cldn5 promoter in mouse brain endothelial cells. Cytokine. 2012 Feb;57(2):269-75.

Attwell D, Mishra A, Hall CN, O'Farrell FM, Dalkara T. What is a pericyte? J Cereb Blood Flow Metab. 2016 Feb;36(2):451-5.

Banks WA, Kastin AJ. Permeability of the blood-brain barrier to melanocortins. Peptides. 1995;16(6):1157-61.

Banks WA. From blood-brain barrier to blood-brain interface: new opportunities for CNS drug delivery. Nat Rev Drug Discov. 2016 Apr;15(4):275-92.

Benson K, Cramer S, Galla HJ. Impedance-based cell monitoring: barrier properties and beyond. Fluids Barriers CNS. 2013 Jan 10;10(1):5.

Bijuklic K, Jennings P, Kountchev J, Hasslacher J, Aydin S, Sturn D, Pfaller W, Patsch JR, Joannidis M. Migration of leukocytes across an endothelium-epithelium bilayer as a model of renal interstitial inflammation. Am J Physiol Cell Physiol. 2007 Jul;293(1):C486-92.

Bocsik A, Walter FR, Gyebrovszki A, Fülöp L, Blasig I, Dabrowski S, Ötvös F, Tóth A, Rákhely G, Veszelka S, Vastag M, Szabó-Révész P, Deli MA. Reversible Opening of Intercellular Junctions of Intestinal Epithelial and Brain Endothelial Cells With Tight Junction Modulator Peptides. J Pharm Sci. 2016 Feb;105(2):754-765. 
Brzoska T, Luger TA, Maaser C, Abels C, Böhm M. Alpha-melanocyte-stimulating hormone and related tripeptides: biochemistry, antiinflammatory and protective effects in vitro and in vivo, and future perspectives for the treatment of immunemediated inflammatory diseases. Endocr Rev. 2008 Aug;29(5):581-602.

Burek M, Förster CY. Cloning and characterization of the murine claudin-5 promoter. Mol Cell Endocrinol. 2009 Jan 27;298(1-2):19-24.

Campos-Bedolla P, Walter FR, Veszelka S, Deli MA. Role of the blood-brain barrier in the nutrition of the central nervous system. Arch Med Res. 2014 Nov;45(8):610-38.

Capaldo CT, Farkas AE, Hilgarth RS, Krug SM, Wolf MF, Benedik JK, Fromm M, Koval M, Parkos C, Nusrat A. Proinflammatory cytokine-induced tight junction remodeling through dynamic self-assembly of claudins. Mol Biol Cell. 2014 Sep 15;25(18):2710-9.

Catania A, Lonati C, Sordi A, Carlin A, Leonardi P, Gatti S. The melanocortin system in control of inflammation. ScientificWorldJournal. 2010 Sep 14;10:1840-53.

Catania A. Neuroprotective actions of melanocortins: a therapeutic opportunity. Trends Neurosci. 2008 Jul;31(7):353-60.

Cereijido M, Contreras RG, Shoshani L, Flores-Benitez D, Larre I. Tight junction and polarity interaction in the transporting epithelial phenotype. Biochim Biophys Acta. 2008 Mar;1778(3):770-93.

de Angelis E, Sahm UG, Ahmed AR, Olivier GW, Notarianni LJ, Branch SK, Moss SH, Pouton CW. Identification of a melanocortin receptor expressed by murine brain microvascular endothelial cells in culture. Microvasc Res. 1995 Jul;50(1):25-34.

De Rotte AA, Bouman HJ, van Wimersma Greidanus TB. Relationships between alphaMSH levels in blood and in cerebrospinal fluid. Brain Res Bull. 1980 JulAug;5(4):375-81.

Deli MA, Abrahám CS, Kataoka Y, Niwa M. Permeability studies on in vitro blood-brain barrier models: physiology, pathology, and pharmacology. Cell Mol Neurobiol. 2005 Feb;25(1):59-127.

Deli MA, Descamps L, Dehouck MP, Cecchelli R, Joó F, Abrahám CS, Torpier G. Exposure of tumor necrosis factor-alpha to luminal membrane of bovine brain capillary endothelial cells cocultured with astrocytes induces a delayed increase of permeability and cytoplasmic stress fiber formation of actin. J Neurosci Res. 1995 Aug 15;41(6):717-26.

Deli MA. Potential use of tight junction modulators to reversibly open membranous barriers and improve drug delivery. Biochim Biophys Acta. 2009 Apr;1788(4):892910.

Didier N, Romero IA, Créminon C, Wijkhuisen A, Grassi J, Mabondzo A. Secretion of interleukin-1 beta by astrocytes mediates endothelin-1 and tumour necrosis factoralpha effects on human brain microvascular endothelial cell permeability. J Neurochem. 2003 Jul;86(1):246-54.

Ding X, Liu CA, Gong JP, Li SW. Pancreatic encephalopathy in 24 patients with severe acute pancreatitis. Hepatobiliary Pancreat Dis Int. 2004 Nov;3(4):608-11.

Engelhardt B, Vajkoczy P, Weller RO. The movers and shapers in immune privilege of the CNS. Nat Immunol. 2017 Feb;18(2):123-131. 
Erickson MA, Banks WA. Neuroimmune Axes of the Blood-Brain Barriers and BloodBrain Interfaces: Bases for Physiological Regulation, Disease States, and Pharmacological Interventions. Pharmacol Rev. 2018 Apr;70(2):278-314.

Ericson MD, Lensing CJ, Fleming KA, Schlasner KN, Doering SR, Haskell-Luevano C. Bench-top to clinical therapies: A review of melanocortin ligands from 1954 to 2016. Biochim Biophys Acta. 2017 Oct;1863(10 Pt A):2414-2435.

Farkas G, Márton J, Nagy Z, Mándi Y, Takács T, Deli MA, Abrahám CS. Experimental acute pancreatitis results in increased blood-brain barrier permeability in the rat: a potential role for tumor necrosis factor and interleukin 6. Neurosci Lett. 1998 Feb 20;242(3):147-50.

Forslin Aronsson A, Spulber S, Oprica M, Winblad B, Post C, Schultzberg M. Alpha-MSH rescues neurons from excitotoxic cell death. J Mol Neurosci. 2007;33(3):239-51.

Fromm MF. Importance of P-glycoprotein at blood-tissue barriers. Trends Pharmacol Sci. 2004 Aug;25(8):423-9.

Groschwitz KR, Hogan SP. Intestinal barrier function: molecular regulation and disease pathogenesis. J Allergy Clin Immunol. 2009 Jul;124(1):3-20; quiz 21-2.

Hassoun HT, Zou L, Moore FA, Kozar RA, Weisbrodt NW, Kone BC. Alpha-melanocytestimulating hormone protects against mesenteric ischemia-reperfusion injury. Am $\mathbf{J}$ Physiol Gastrointest Liver Physiol. 2002 Jun;282(6):G1059-68

Hoogland IC, Houbolt C, van Westerloo DJ, van Gool WA, van de Beek D. Systemic inflammation and microglial activation: systematic review of animal experiments. $\mathrm{J}$ Neuroinflammation. 2015 Jun 6;12:114.

Hruby VJ, Wilkes BC, Hadley ME, Al-Obeidi F, Sawyer TK, Staples DJ, de Vaux AE, Dym O, Castrucci AM, Hintz MF, et al. alpha-Melanotropin: the minimal active sequence in the frog skin bioassay. J Med Chem. 1987 Nov;30(11):2126-30.

Huang Q, Tatro JB. Alpha-melanocyte stimulating hormone suppresses intracerebral tumor necrosis factor-alpha and interleukin-1beta gene expression following transient cerebral ischemia in mice. Neurosci Lett. 2002 Dec 16;334(3):186-90.

Joosten EA, Verhaagh S, Martin D, Robe P, Franzen R, Hooiveld M, Doornbos R, Bär PR, Moonen G. Alpha-MSH stimulates neurite outgrowth of neonatal rat corticospinal neurons in vitro. Brain Res. 1996 Oct 14;736(1-2):91-8.

Kalden DH, Scholzen T, Brzoska T, Luger TA. Mechanisms of the antiinflammatory effects of $\alpha$-MSH. Role of transcription factor $\mathrm{NF}-\kappa \mathrm{B}$ and adhesion molecule expression. Ann N Y Acad Sci. 1999;885:254-61

Kastin AJ, Fabre LA. Limitations to effect of alpha-MSH on permeability of blood-brain barrier to IV 99mTc-pertechnetate. Pharmacol Biochem Behav. 1982 Dec;17(6):1199-201.

Kiss L, Walter FR, Bocsik A, Veszelka S, Ozsvári B, Puskás LG, Szabó-Révész P, Deli MA. Kinetic analysis of the toxicity of pharmaceutical excipients Cremophor EL and RH40 on endothelial and epithelial cells. J Pharm Sci. 2013 Apr;102(4):117381.

Kovács J, Julesz J, Mogyoróssy MV, Deli MA, Abrahám CS, Vecsernyés M. Asphyxiainduced release of $\alpha$-melanocyte-stimulating hormone in newborn pigs. Peptides. $2001 \mathrm{Jul} ; 22(7): 1049-53$. 
König J, Wells J, Cani PD, García-Ródenas CL, MacDonald T, Mercenier A, Whyte J, Troost F, Brummer RJ. Human Intestinal Barrier Function in Health and Disease. Clin Transl Gastroenterol. 2016 Oct 20;7(10):e196.

Krizbai IA, Fazakas C, Haskó J, Molnár J, Nyúl-Tóth Á, Farkas AE, Wilhelm I. Molecular structure and function of biological barriers. Acta Biol Szeged. 2015;59(Suppl.1):39-50.

Lasaga M, Debeljuk L, Durand D, Scimonelli TN, Caruso C. Role of alpha-melanocyte stimulating hormone and melanocortin 4 receptor in brain inflammation. Peptides. 2008 Oct;29(10):1825-35.

Lee SH. Intestinal permeability regulation by tight junction: implication on inflammatory bowel diseases. Intest Res. 2015 Jan;13(1):11-8.

Lee YW, Hennig B, Fiala M, Kim KS, Toborek M. Cocaine activates redox-regulated transcription factors and induces TNF-alpha expression in human brain endothelial cells. Brain Res. 2001 Nov 30;920(1-2):125-33.

Liebner S, Dijkhuizen RM, Reiss Y, Plate KH, Agalliu D, Constantin G. Functional morphology of the blood-brain barrier in health and disease. Acta Neuropathol. 2018 Mar;135(3):311-336.

Lopez-Ramirez MA, Fischer R, Torres-Badillo CC, Davies HA, Logan K, Pfizenmaier K, Male DK, Sharrack B, Romero IA. Role of caspases in cytokine-induced barrier breakdown in human brain endothelial cells. J Immunol. 2012 Sep 15;189(6):31309.

Maaser C, Kannengiesser K, Specht C, Lügering A, Brzoska T, Luger TA, DomschkeW, Kucharzik T. Crucial role of the melanocortin receptor MC1R in experimental colitis. Gut. 2006 Oct;55(10):1415-22.

Magnoni S, Stocchetti N, Colombo G, Carlin A, Colombo A, Lipton JM, Catania A. Alpha-melanocyte-stimulating hormone is decreased in plasma of patients with acute brain injury. J Neurotrauma. 2003 Mar;20(3):251-60.

Makó V, Czúcz J, Weiszhár Z, Herczenik E, Matkó J, Prohászka Z, Cervenak L.Proinflammatory activation pattern of human umbilical vein endothelial cells induced by IL-1 $\beta$, TNF- $\alpha$, and LPS. Cytometry A. 2010 Oct;77(10):962-70.

Manna SK, Aggarwal BB. Alpha-melanocyte-stimulating hormone inhibits the nuclear transcription factor NF-kappa B activation induced by various inflammatory agents. J Immunol. 1998 Sep 15;161(6):2873-80.

Megyeri P, Abrahám CS, Temesvári P, Kovács J, Vas T, Speer CP. Recombinant human tumor necrosis factor alpha constricts pial arterioles and increases blood-brain barrier permeability in newborn piglets. Neurosci Lett. 1992 Dec 14;148(1-2):13740.

Nakagawa S, Deli MA, Kawaguchi H, Shimizudani T, Shimono T, Kittel A, Tanaka K, Niwa M. A new blood-brain barrier model using primary rat brain endothelial cells, pericytes and astrocytes. Neurochem Int. 2009 Mar-Apr;54(3-4):253-63.

Nalle SC, Turner JR. Intestinal barrier loss as a critical pathogenic link between inflammatory bowel disease and graft-versus-host disease. Mucosal Immunol. 2015 Jul;8(4):720-30. 
Neuwelt EA, Bauer B, Fahlke C, Fricker G, Iadecola C, Janigro D, Leybaert L, Molnár Z, O'Donnell ME, Povlishock JT, Saunders NR, Sharp F, Stanimirovic D, Watts RJ, Drewes LR. Engaging neuroscience to advance translational research in brain barrier biology. Nat Rev Neurosci. 2011 Mar;12(3):169-82.

Oshima T, Miwa H, Joh T. Changes in the expression of claudins in active ulcerative colitis. J Gastroenterol Hepatol. 2008 Dec;23 Suppl 2:S146-50.

Pardridge WM. Drug and gene targeting to the brain with molecular Trojan horses. Nat Rev Drug Discov. 2002 Feb;1(2):131-9.

Perrière N, Demeuse P, Garcia E, Regina A, Debray M, Andreux JP, Couvreur P, Scherrmann JM, Temsamani J, Couraud PO, Deli MA, Roux F. Puromycin-based purification of rat brain capillary endothelial cell cultures. Effect on the expression of blood-brain barrier-specific properties. J Neurochem. 2005 Apr;93(2):279-89.

Pires BRB, Silva RCMC, Ferreira GM, Abdelhay E. NF-kappaB: Two Sides of the Same Coin. Genes (Basel). 2018 Jan 9;9(1). pii: E24.

Rajora N, Boccoli G, Catania A, Lipton JM. Alpha-MSH modulates experimental inflammatory bowel disease. Peptides. 1997;18(3):381-5.

Ramadan Q, Jing L. Characterization of tight junction disruption and immune response modulation in a miniaturized Caco-2/U937 coculture-based in vitro model of the human intestinal barrier. Biomed Microdevices. 2016;18(1).

Rochfort KD, Cummins PM. The blood-brain barrier endothelium: a target for proinflammatory cytokines. Biochem Soc Trans. 2015 Aug;43(4):702-6.

Rosenberg GA. Neurological diseases in relation to the blood-brain barrier. J Cereb Blood Flow Metab. 2012 Jul;32(7):1139-51.

Sankar R, Domer FR, Kastin AJ. Selective effects of alpha-MSH and MIF-1 on the bloodbrain barrier. Peptides. 1981 Fall;2(3):345-7.

Sántha P, Veszelka S, Hoyk Z, Mészáros M, Walter FR, Tóth AE, Kiss L, Kincses A, Oláh Z, Seprényi G, Rákhely G, Dér A, Pákáski M, Kálmán J, Kittel Á, Deli MA. Restraint Stress-Induced Morphological Changes at the Blood-Brain Barrier in Adult Rats. Front Mol Neurosci. 2016 Jan 14;8:88.

Schiöth HB, Mutulis F, Muceniece R, Prusis P, Wikberg JE. Discovery of novel melanocortin4 receptor selective $\mathrm{MSH}$ analogues. $\mathrm{Br} \mathrm{J}$ Pharmacol. 1998 May;124(1):75-82.

Sochocka M, Diniz BS, Leszek J. Inflammatory Response in the CNS: Friend or Foe? Mol Neurobiol. 2017 Dec;54(10):8071-8089.

Van De Walle J, Hendrickx A, Romier B, Larondelle Y, Schneider YJ. Inflammatory parameters in Caco-2 cells: effect of stimuli nature, concentration, combination and cell differentiation. Toxicol In Vitro. 2010;24(5):1441-9.

Varga B, Gesztelyi R, Bombicz M, Haines D, Szabo AM, Kemeny-Beke A, Antal M, Vecsernyes M, Juhasz B, Tosaki A. Protective effect of alpha-melanocytestimulating hormone $(\alpha-\mathrm{MSH})$ on the recovery of ischemia/reperfusion (I/R)induced retinal damage in a rat model. J Mol Neurosci. $2013 \mathrm{Jul} ; 50(3): 558-70$.

Vecsernyes M, Juhasz B, Der P, Kocsan R, Feher P, Bacskay I, Kovacs P, Tosaki A. The administration of alpha-melanocyte-stimulating hormone protects theischemic/reperfused myocardium. Eur J Pharmacol. 2003 Jun 6;470(3):177-83. 
Vecsernyes M, Szokol M, Bombicz M, Priksz D, Gesztelyi R, Fulop GA, Varga B, Juhasz B, Haines D, Tosaki A. Alpha-Melanocyte-stimulating Hormone Induces Vasodilation and Exerts Cardioprotection Through the Heme-Oxygenase Pathway in Rat Hearts. J Cardiovasc Pharmacol. 2017 May;69(5):286-297.

Veszelka S, Pásztói M, Farkas AE, Krizbai I, Ngo TK, Niwa M, Abrahám CS, Deli MA. Pentosan polysulfate protects brain endothelial cells against bacterial lipopolysaccharide-induced damages. Neurochem Int. 2007 Jan;50(1):219-28.

Veszelka S, Tóth A, Walter FR, Tóth AE, Gróf I, Mészáros M, Bocsik A, Hellinger É, Vastag M, Rákhely G and Deli MA. Comparison of a Rat Primary Cell-Based Blood-Brain Barrier Model With Epithelial and Brain Endothelial Cell Lines: Gene Expression and Drug Transport. Front. Mol. Neurosci. 2018 May 22;1 1:166

Veszelka S, Tóth AE, Walter FR, Datki Z, Mózes E, Fülöp L, Bozsó Z, Hellinger E, Vastag M, Orsolits B, Környei Z, Penke B, Deli MA. Docosahexaenoic acid reduces amyloid- $\beta$ induced toxicity in cells of the neurovascular unit. J Alzheimers Dis. 2013;36(3):487-501.

Walter FR, Veszelka S, Pásztói M, Péterfi ZA, Tóth A, Rákhely G, Cervenak L, Ábrahám CS, Deli MA. Tesmilifene modifies brain endothelial functions and opens the blood-brain/blood-glioma barrier. J Neurochem. 2015 Sep;134(6):1040-54.

Wang J, Lopez-Fraga M, Rynko A, Lo DD. TNFR and LT $\beta R$ agonists induce follicleassociated epithelium and $M$ cell specific genes in rat and human intestinal epithelial cells. Cytokine. 2009 Jul;47(1):69-76.

Wilson JF. Low permeability of the blood-brain barrier to nanomolar concentrations of immunoreactive alpha-melanotropin. Psychopharmacology (Berl). 1988;96(2):2626.

Youdim KA, Avdeef A, Abbott NJ. In vitro trans-monolayer permeability calculations: often forgotten assumptions. Drug Discov Today. 2003 Nov 1;8(21):997-1003.

Zou L, Sato N, Attuwaybi BO, Kone BC. Delayed administration of $\alpha$-melanocytestimulating hormone or combined therapy with BAY 11-7085protects against gut ischemia-reperfusion injury. Shock. 2003 Nov;20(5):469-75.

Zou L, Sato N, Kone BC. Alpha-melanocyte stimulating hormone protects against $\mathrm{H}_{2} \mathrm{O}_{2}-$ induced inhibition of wound restitution in IEC-6 cells via a Syk kinase- and NF- $\kappa$ Bdependent mechanism. Shock. 2004 Nov;22(5):453-9. 


\section{8. Összefoglaló}

\section{Az $\alpha$-melanocita stimuláló hormon gyulladáscsökkentő hatása biológiai gátrendszerek tenyészetes modelljein}

A soksejtü szövetes szervezeteket különböző, hámszöveti sejtek alkotta gátrendszerek határolják. A legnagyobb külső határfelületnek tekinthető barrier a bélcsatorna nyálkahártyája, amely megakadályozza, hogy káros anyagok, bélbaktériumok, vagy kórokozók bejussanak a szervezetbe, ugyanakkor felszínt biztosít az emésztéshez és a táplálékfelvételhez. Az egyik legfontosabb vér-szöveti gátrendszerünk a központi idegrendszer ionos homeosztázisát és az idegsejtek megfelelő tápanyag-ellátottságát biztosító vér-agy gát. Mindkét barrier anatómiai alapját az egyes gátrendszerek sejtjeit egymáshoz kapcsoló szoros kapcsolatok képezik, melyek fizikailag akadályozzák a kórokozók és anyagok átjutását és a sejteknek polaritást adva biztosítják a molekulák szabályozott transzportját.

A gátrendszerek dinamikus határfelületeinek homeosztázist fenntartó és védőfunkciói nemcsak élettani körülmények között fontosak, hanem betegségekben is. A legtöbb kórtani állapotban helyi, vagy akár szisztémás gyulladásos folyamatok figyelhetőek meg, amelyek alapvetően befolyásolják a barrierek müködését. A gyulladáskeltő citokinek közül a TNF- $\alpha$ és az IL-1 $\beta$ a két leginkább tanulmányozott molekula. Egyaránt részt vesznek gyulladásos bélbetegségekben, valamint központi idegrendszeri gyulladásos folyamatokban és a gátrendszerek sérülését és áteresztöképességük fokozódását váltják ki. Kísérleteinkhez ezért ezt a két citokint választottuk.

Az $\alpha$-melanocita stimuláló hormon egy endogén peptid, amely a melanokortinok csoportjába tartozik. Az allergiás és gyulladásos megbetegedésekben gyakorolt védőhatása kiterjedt kutatások tárgyát képezi. Az $\alpha$-MSH bélrendszert védő hatását írták le akut és krónikus vastagbélgyulladás patkánymodelljein, illetve a bélrendszerben előforduló iszkémiában is. Emellett a peptid neuroprotektív hatását figyelték meg bakteriális lipopoliszacharid által kiváltott agyi gyulladásban, agyi érelzáródásban, kainsav kiváltotta, valamint traumás agysérülésekben is. Mindezidáig azonban még nem vizsgálták az $\alpha-\mathrm{MSH}$ hatását a vér-agy gátra, illetve citokinnel kezelt bélepitélsejtekre. Célunk ezért az volt, hogy megvizsgáljuk az $\alpha$-MSH közvetlen védöhatását a bélepitél és a vér-agy gát tenyészetes modelljein, amelyeket gyulladáskeltő citokinekkel kezeltünk. 
A melanokortin receptorok közül a hormon elsődleges és leggyakoribb receptora az MC1R. Munkánk során immunhisztokémiával kimutattuk a humán Caco-2 bélepitélsejtvonalon az MC1R polarizált expresszióját: a sejtek apikális felszínén több immunfestéssel kimutatható receptort találtunk, mint a bazális felszínén. PCR- és immunhisztokémiai eredményeink mind RNS-, mint fehérjeszinten igazolták az MC1R jelenlétét izolált patkány agyi mikroereken és az ezekből tenyésztett agyi endotélsejteken. Mindezek alapján feltételeztük, hogy az $\alpha$-MSH peptid közvetlen hatást gyakorolhat ezekre a sejttípusokra is.

A hormon koncentrációja a vérben igen alacsony, pikomólos tartományban mozog, mely kóros körülmények között megváltozik. A vér-agy gáton élettani körülmények között alacsony az átjutása az intravénásan beadott peptidnek, míg kórosan magas vagy farmakológiai koncentrációban átjut az $\alpha-\mathrm{MSH}$ a vér-agy gáton. Valósidejü setjanalízis és MTT-teszt során széles koncentrációtartományban vizsgálva $(1 \mathrm{pM}-1 \mu \mathrm{M})$ a hormon nem befolyásolta az agyi endotélsejtek növekedését, a sejtréteg integritását, és nem okozott sejtkárosodást.

A két legfontosabb gyulladáskeltő citokin, a TNF- $\alpha$ és az IL-1 $\beta$ kombinációjával történő kezelés hatására a Caco-2 bélepitélsejtek közötti paracelluláris útvonal megnyílt. Citokinkezelés hatására a sejtréteg két oldala között mérhető transzepiteliális elektromos ellenállás leesett, a sejtréteg áteresztőképessége jelzőmolekulákra megemelkedett kísérleteinkben. Az $\alpha$-MSH hormon kivédte a citokinek által kiváltott ellenálláscsökkenést, mely védőhatás nem volt egyenes arányos a növekvő peptidkoncentrációval, hanem más peptidhormonokhoz hasonlóan, harang alakú hatásgörbe jellemezte. A leghatékonyabb koncentrációban adva a peptidet a jelzőanyagok permeabilitása mérséklődött. A sejtek közötti szoros kapcsolatok immunfestődését vizsgálva a Caco-2 bélepitélsejteken citokinkezelés hatására mind a klaudin-4 integráns sejtkapcsoló membránfehérje, mind a ZO-1 linkerfehérje a sejthatárokon felszakadozott, és a sejtmembránból a citoplazmába átrendeződött. Az $\alpha-\mathrm{MSH}$ peptiddel történő kezelés azonban az epitélsejtek közötti kapcsolatok morfológiájának kontrollcsoporthoz hasonló visszaállását eredményezte.

A TNF- $\alpha$ és IL-1 $\beta$ citokinek a vér-agy gát tenyészetes modelljén is csökkentették a sejtréteg impedanciáját valósidejü sejtanalízis során, és megemelték az endotélsejtek áteresztőképességét permeabilitási kísérletekben. Kis koncentrációjú $\alpha$-MSH-kezelés ezeket a hatásokat enyhítette, megemelte az impedanciát és mérsékelte a kis molekulatömegü dextrán és a nagy molekulatömegü albumin jelzőanyagok átjutását. A citokinek az agyi endotélsejtek közötti sejtkapcsoló fehérjék immunfestődését is 
megváltoztatták: az endotélsejt specifikus klaudin-5 membránfehérje és a $\beta$-katenin linkerfehérje festődésének felszakadozását, citoplazmatikus átrendeződését eredményezték. A gyulladáskeltő citokinek sejtkapcsolatok morfológiájára kifejtett hatása azonban $\alpha$-MSH peptiddel történő kezelés hatására mérséklődött, a sejthatárok szerkezete helyreállt, és a citoplazmában a festődés csökkent.

A bélepitélsejtek permeabilitásának gyulladáskeltő citokinek hatására bekövetkező fokozódása a sejtkapcsoló fehérjék kifejeződésének, lokalizációjának megváltozásával járt,

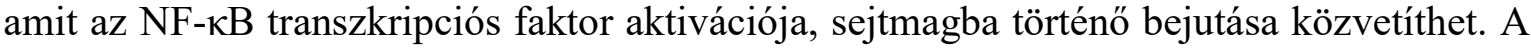
transzkripciós faktor p65 alegységének immunfestődését vizsgálva citokinkezelés hatására megemelkedett a fehérje sejtmagi jelenléte, mely $\alpha$-MSH peptiddel történő kezelés hatására mérséklődött.

A legtöbb gyulladásos folyamattal együtt járó oxidatív stressz az egyik fő mechanizmusa a gyulladások okozta idegsejt-károsodásnak. A citokinek okozta megemelkedett ROS-termelődés azonban $\alpha$-MSH-kezelést követően visszafordíthatónak bizonyult. Mind a TNF- $\alpha$, mind az IL-1 $\beta$ képes aktiválni az NF- $\kappa B$ útvonalat agyi endotélsejtekben. Immunhisztokémiai vizsgálataink során a citokinkezelés hatására az NF$\kappa \mathrm{B}$ fehérje a sejtmagba jutott, és ezt a hatást az $\alpha-\mathrm{MSH}$ peptid gátolta.

Az $\alpha$-MSH peptid gyulladásos folyamatokkal szembeni védőhatását számos állatkísérletes modellen és sejttípusban leírták korábban, de Caco-2 bélepitélsejteken és agyi endotélsejteken eddig nem állt rendelkezésre adat. Munkánk során bizonyítottuk, hogy az $\alpha$-MSH elsődleges receptorának tekinthető MC1R fehérje mind a humán Caco-2 bélepitélsejtvonalon, mind patkány agyi endotélsejteken kifejeződik, és az utóbbi sejtekre széles koncentrációtartományban sincs károsító hatása. Gyulladásos körülmények között kimutattuk, hogy az $\alpha$-MSH peptid mind a bélepitélium, mind a vér-agy gát tenyészetes modelljein védőhatású. $\mathrm{Az} \alpha-\mathrm{MSH}$ az $\mathrm{NF}-\kappa \mathrm{B}$ jelátviteli útvonal gátlásán keresztül csökkentette agyi endotélsejtekben az oxigéngyökök termelődését, és mindkét modellen mérsékelte a citokinek okozta permeabilitásfokozódást, és az ezzel párhuzamosan kialakuló változást a sejtkapcsoló fehérjék immunfestődési mintázatában. Az általunk vizsgált két biológiai gátrendszer tenyészetes modelljein tehát az $\alpha$-MSH peptid, legalábbis részben, az NF-kB fehérje sejtmagba történő bejutásának gátlásával biztosítja a sejtkapcsoló fehérjék kifejeződésének és a barrierek megfelelő működésének visszaállását citokinek okozta károsodásban. Mindezek az eredmények megerősítik az $\alpha$-MSH hormon jótékony hatását a biológiai barrierek védelmében. 


\section{Summary}

\section{Anti-inflammatory effects of $\alpha$-melanocyte stimulating hormone on culture models of biological barriers}

Multicellular organisms have different epithelial barriers covering the surface of the body and body cavities. The biggest outer barrier is the intestinal mucosa, which prevents the entry of xenobiotics, harmful agents, gut bacteria or pathogens into the body, and provides a surface for digestion and food uptake. One of our most important blood-tissue barrier is the blood-brain barrier, which insures the ionic homeostasis and nutrient supply of the central nervous system. The anatomical basis of both barriers consists of intercellular tight junctions, which connect barrier cells physically preventing the entry of various pathogens and compounds, and add polarity to these cells, providing a regulated transport of molecules.

The maintainence of homeostasis and protection of the organism afforded by the dynamic interface of barriers are important not only under physiological conditions, but in diseases too. In most forms of pathology local or systemic inflammation occurs, which influences barrier functions. Among inflammatory cytokines TNF- $\alpha$ and IL-1 $\beta$ are the most studied molecules. Both of them participate in inflammatory bowel diseases and in neuroinflammation inducing barrier impairment and increase in permeability. Therefore we have chosen these two cytokines for our experiments.

The $\alpha$-melanocyte stimulating hormone is an endogenous peptide from the group of melanocortins. Its protective effect in allergic and inflammatory diseases is widely investigated. Protective effects of $\alpha$-MSH were reported in rat models of acute and chronic colitis, and in instestinal ischemia. Moreover, neuroprotective effects of the peptide were observed in brain inflammation induced by bacterial lipopolisaccharide, in brain ischemia, and in kainic acid induced or traumatic brain injury, too. However, $\alpha$-MSH effects have not been studied either at the blood-brain barrier, or cytokine treated intestinal epithelial cells. Therefore, our aim was to investigate the direct protective effects of $\alpha-\mathrm{MSH}$ on culture models of the gut epithelium and the blood-brain barrier following pro-inflammatory cytokine treatments.

Among melanocortin receptors MC1R is the main and most abundant receptor of $\alpha$ MSH. In our work, using immunocytochemistry, we demonstrated the polarized expression of $\mathrm{MC1R}$ in the human Caco-2 intestinal cell line: more immunoreactive receptors were 
observed at the apical surface of the cells than at the basal surface. Our PCR and immunhistochemical results verified the presence of MC1R both at RNA and protein level in isolated rat brain microvessels and in cultured brain endothelial cells derived from microvessels. Based on these data, we hypothesized that the $\alpha$-MSH peptide had direct effects on these cell types.

The concentration of the hormone is quite low in the blood, it is in picomolar range under physiological conditions, but it changes when pathological alterations are taking place. A low permeability for intravenously injected $\alpha$-MSH was measured across the blood-brain barrier at physiological concentrations, while at pathologically high or pharmacological concentrations the peptide crossed the blood-brain barrier. As demonstrated by real time cell electronic sensing and MTT test, $\alpha$-MSH did not alter the growth of cultured brain endothelial cells, or the integrity of the cell layer, nor cause cell damage in a wide range of concentrations $(1 \mathrm{pM}-1 \mu \mathrm{M})$.

The paracellular pathway between Caco-2 intestinal epithelial cells opened due to the combined treatment with the two most important cytokines, TNF- $\alpha$ and IL-1 $\beta$. The cytokine treatment resulted in a decrease in the transepithelial electrical resistance between the two sides of the cell layer, and in an increase in permeability for marker molecules. The $\alpha$-MSH hormone inhibited the decrease in resistance induced by cytokine treatment. This protective effect was not directly proportional with the increase of the hormone concentration. It showed, like other peptide hormones, a bell-shape dose-response curve. $\alpha$ MSH applied in its effective dose reduced the increase in permeability for marker molecules. Analysis of the immunocytochemical staining pattern of intercellular tight junction proteins revealed that both claudin- 4 junctional protein and ZO-1 linker protein showed interruptions at cell borders and translocated from the cell membrane to the cytoplasm in Caco-2 intestinal cell line epithelial cells following cytokine treatment. $\alpha$ MSH treatment, in contrast, restored the morphology of interepithelial junctions, resulting in a pattern similar to that observed in the control group.

TNF- $\alpha$ and IL-1 $\beta$ pro-inflammatory cytokines induced a decrease in the impedance of the cell layer measured by real time cell electronic sensing, and an increase in permeability of endothelial cells in the culture model of the blood-brain barrier too. Treatments with $\alpha-\mathrm{MSH}$ at low concentration attenuated these effects: an increase in the impedance and a reduction of the increase in permeability for the small molecular weight dextran and big molecular weight albumin were detected. Due to cytokine treatments the immunostaining pattern of junctional proteins between brain endothelial cells was also 
changed: the immunolabelings of endothelial specific claudin-5 membrane protein and $\beta$ catenin linker protein showed disrupted lines, and cytoplasmic redistributions were observed. Treatment with the $\alpha$-MSH peptide attenuated the effects of pro-inflammatory cytokines on the morphology of cellular junctions: the cell border labeling was restored and the cytoplasmic immunosstaining was decreased.

The cytokine induced increase in permeability of intestinal epithelial cells, and changes in the expression and localization of cellular junctional proteins occured parallely, which can be mediated by the activation and nuclear translocation of the transcription factor NF- $\mathrm{BB}$. Analysis of the immunoreactivity pattern of the p65 subunit of the transcription factor showed an increase in the nuclear staining of the protein due to cytokine treatment, which was attenuated by $\alpha-\mathrm{MSH}$.

Most inflammatory conditions are accompanied by oxidative stress, which is one of the main mechanisms of inflammation related neuronal damage. Cytokine induced elevated reactive oxygen species production was reversed after $\alpha$-MSH treatment. Both TNF- $\alpha$ and IL-1 $\beta$ can activate the NF- $\kappa B$ signaling pathway in brain endothelial cells. Our immunocytochemical studies demonstrated that NF- $\kappa \mathrm{B}$ translocated to cell nuclei due to cytokine treatment. This effect was inhibited by $\alpha-\mathrm{MSH}$.

Anti-inflammatory effects of the $\alpha$-MSH peptide were described previously in several animal models and cell types, but there were no data regarding Caco-2 intestinal epithelial cells and brain endothelial cells. In the present work we proved that MC1R, the main receptor of $\alpha-\mathrm{MSH}$, is expressed both in the human Caco-2 intestinal cell line and in rat brain endothelial cells. The peptide does not impair rat brain endothelial cells even in a wide range of concentrations. In inflammatory conditions we demonstrated that $\alpha$-MSH is protective both in culture models of the gut epithelium and of the blood-brain barrier. The $\alpha$-MSH peptide reduced the production of reactive oxygen species in brain endothelial cells by inhibiting the NF- $\mathrm{kB}$ signaling pathway. The hormone attenuated the cytokine induced increases in permeability and changes in the immunostaining pattern of cellular junctional proteins, occurring parallely. In our culture models of two biological barriers $\alpha$ $\mathrm{MSH}$, at least partly, insures the recovery of junctional protein expressions and restores appropriate barrier functions in cytokine induced damage by inhibition of the nuclear translocation of NF- $\kappa$ B. All these results strengthen the beneficial effects of $\alpha-\mathrm{MSH}$ contributing to the protection of biological barriers. 
10. Függelék 
I. publikáció 


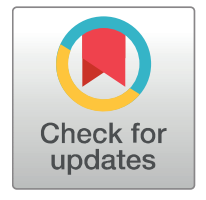

\section{G openacCess}

Citation: Váradi J, Harazin A, Fenyvesi F, Réti-Nagy K, Gogolák P, Vámosi G, et al. (2017) AlphaMelanocyte Stimulating Hormone Protects against Cytokine-Induced Barrier Damage in Caco-2 Intestinal Epithelial Monolayers. PLOS ONE 12(1): e0170537. doi:10.1371/journal.pone.0170537

Editor: Zoltán Rakonczay, Jr., University of Szeged, HUNGARY

Received: October 24, 2016

Accepted: January 5, 2017

Published: January 19, 2017

Copyright: ( 2017 Váradi et al. This is an open access article distributed under the terms of the Creative Commons Attribution License, which permits unrestricted use, distribution, and reproduction in any medium, provided the original author and source are credited.

Data Availability Statement: All relevant data are within the paper and its Supporting Information files.

Funding: FF was supported by János Bólyai Research Scolarship of the Hungarian Academy of Sciences (BO/00290/16/5). The funder had no role in study design, data collection and analysis, decision to publish, or preparation of the manuscript.
RESEARCH ARTICLE

\section{Alpha-Melanocyte Stimulating Hormone Protects against Cytokine-Induced Barrier Damage in Caco-2 Intestinal Epithelial Monolayers}

\author{
Judit Váradi ${ }^{1}$, András Harazin ${ }^{2}$, Ferenc Fenyvesi ${ }^{1}$, Katalin Réti-Nagy ${ }^{1}$, Péter Gogolák ${ }^{3}$, \\ György Vámosi ${ }^{4}$, Ildikó Bácskay ${ }^{1}$, Pálma Fehér ${ }^{1}$, Zoltán Ujhelyi ${ }^{1}$, Gábor Vasvári ${ }^{1}$, \\ Eszter Róka ${ }^{1}$, David Haines ${ }^{1,5}$, Mária A. Deli ${ }^{2}$, Miklós Vecsernyés ${ }^{1}$ \\ 1 Department of Pharmaceutical Technology, Faculty of Pharmacy, University of Debrecen, Debrecen, \\ Hungary, 2 Institute of Biophysics, Biological Research Centre, Hungarian Academy of Sciences, Szeged, \\ Hungary, 3 Department of Immunology, Faculty of Medicine, University of Debrecen, Debrecen, Hungary, \\ 4 Department of Biophysics and Cell Biology, Faculty of Medicine, University of Debrecen, Debrecen, \\ Hungary, 5 Department of Pharmacology, Faculty of Pharmacy, University of Debrecen, Debrecen, Hungary \\ *varadi.judit@pharm.unideb.hu
}

\section{Abstract}

Alpha-melanocyte-stimulating hormone $(\alpha-M S H)$ is a potent anti-inflammatory peptide with cytoprotective effect in various tissues. The present investigation demonstrates the ability of $\mathrm{a}-\mathrm{MSH}$ to interact with intestinal epithelial cell monolayers and mitigate inflammatory processes of the epithelial barrier. The protective effect of $\alpha-\mathrm{MSH}$ was studied on Caco-2 human intestinal epithelial monolayers, which were disrupted by exposure to tumor necrosis factor- $\alpha$ and interleukin- $1 \beta$. The barrier integrity was assessed by measuring transepithelial electric resistance (TEER) and permeability for marker molecules. Caco-2 monolayers were evaluated by immunohistochemistry for expression of melanocortin-1 receptor and tight junction proteins ZO-1 and claudin-4. The activation of nuclear factor kappa beta (NF-kB) was detected by fluorescence microscopy and inflammatory cytokine expression was assessed by flow cytometric bead array cytokine assay. Exposure of Caco-2 monolayers to proinflammatory cytokines lowered TEER and increased permeability for fluorescein and albumin, which was accompanied by changes in ZO-1 and claudin-4 immunostaining. $\alpha$ MSH was able to prevent inflammation-associated decrease of TEER in a dose-dependent manner and reduce the increased permeability for paracellular marker fluorescein. Further immunohistochemistry analysis revealed proinflammatory cytokine induced translocation of the NF-KB p65 subunit into Caco-2 cell nuclei, which was inhibited by $\alpha-\mathrm{MSH}$. As a result the IL-6 and IL-8 production of Caco-2 monolayers were also decreased with different patterns by the addition of $\alpha-\mathrm{MSH}$ to the culture medium. In conclusion, Caco-2 cells showed a positive immunostaining for melanocortin-1 receptor and $\alpha-\mathrm{MSH}$ protected Caco- 2 cells against inflammatory barrier dysfunction and inflammatory activation induced by tumor necrosis factor- $\alpha$ and interleukin- $1 \beta$ cytokines. 
Competing Interests: The authors confirm that there are no conflicts of interest with respect to any of the topic material presented herein.

\section{Introduction}

Epithelial cells are key components of the intestinal barrier by forming tight junctions (TJ) sealing the paracellular cleft, thus restricting free flux of cells and molecules from the gut to the blood. Dysfunction of the epithelial barrier is a common feature in inflammatory diseases of the gastrointestinal system [1]. The damage of the protective epithelial barrier contributes to the pathomechanism and both local and systemic inflammation. Proinflammatory cytokines tumor necrosis factor- $\alpha$ (TNF- $\alpha$ ) and interleukin-1 $\beta$ (IL-1 $\beta$ ) are overexpressed in inflammatory bowel diseases and directly damage the intestinal barrier including the interepithelial TJs [1]. Cell culture models of intestinal epithelium are widely used in the characterization of gut disease pathomechanisms, and to evaluate selected pharmacotherapies. The Caco-2 human intestinal epithelial cell line is a well-characterized model to study intestinal absorption pro-

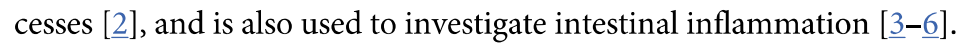

Since TNF- $\alpha$ and IL-1 $\beta$ are pathogenic factors in intestinal inflammation, they are used in both animal and culture models to induce epithelial cell inflammation and barrier opening. These cytokines induce initiation and amplification of inflammatory cellular processes which alter Caco-2 function, such as cell layer permeability, in ways that can be used as the model of inflamed bowel epithelium [ $2-\underline{9}$ ]. Treatment of Caco- 2 cells with TNF- $\alpha$ or IL-1 $\beta$ decrease the electrical resistance of monolayers and increase IL-8 production indicating epithelial barrier opening and inflammatory response $[8,10,11]$. In our previous study we described, that claudin4 , a sealing claudin, is the most expressed member of the claudin family after claudin-1 in Caco2 cells [12]. Claudin- 4 was described as an important element of the intestinal barrier in both colon tissue of mice and Caco-2 cells with a significant downregulation in inflammation [13].

A prominent member of the melanocortin system, $\alpha-\mathrm{MSH}$, regulates crucial aspects of not only melanogenesis but also inflammation in various cell types [14]. The antiinflammatory effects of $\alpha-\mathrm{MSH}$ are mediated by the inhibition of NF- $\kappa \mathrm{B}$ induced inflammatory processes, like activation and proliferation of lymphocytes, and proinflammatory cytokine production $[\underline{15}, \underline{16}]$. Due to this protective action the therapeutical potential of $\alpha-\mathrm{MSH}$ has been widely examined in immune-mediated pathologies, like allergic and inflammatory diseases of the skin and lung, ocular inflammation, arthritis, and inflammatory bowel disease [16]. The antiinflammatory effects of $\alpha-\mathrm{MSH}$ have been examined in animal models of intestinal injury. In a rat model of chemically induced acute and chronic colitis $\alpha-\mathrm{MSH}$ reduced pathological weight loss, fecal blood, TNF- $\alpha$ and nitric oxide production in colon tissue [17] and macroscopic colitis lesions [18]. Protective effect of $\alpha-\mathrm{MSH}$ was also described in rat models of intestinal ische$\mathrm{mia} /$ reperfusion, where NF- $\mathrm{KB}$ induced inflammation has a central role in the pathomechanism $[\underline{19}, \underline{20}]$.

The immunomodulatory action of $\alpha-\mathrm{MSH}$ is regulated by melanocortin receptors MC1, MC3, MC4 and MC5 [16]. The presence of MC1R, the most important receptor responsible for mediating the antiinflammatory effects of $\alpha-\mathrm{MSH}$, was demonstrated on intestinal epithelium in mice [21]. The crucial role of this receptor in inflammatory gut disease was demonstrated in sophisticated mouse models, where the absence of a functional MC1R resulted in the aggravation of different types of experimental colitis indicating the protective role of the $\alpha$ MSH-MCR1 pathway on non-hematopoietic cells [21].

Based on these data we hypothesized a direct protective action of $\alpha-\mathrm{MSH}$ on cytokineinduced barrier dysfunction and inflammatory activation in the human Caco-2 epithelial cell line, which has not been investigated, yet. Therefore the aims of the present study were: (i) demonstration of the presence of MC1R on Caco-2 epithelial cells, (ii) testing the effects of $\alpha$ MSH on TNF- $\alpha$ and IL-1 $\beta$ treatment induced barrier damage by measurement of transepithelial electric resistance (TEER) and permeability for marker molecules, and visualization of TJ 
proteins ZO- 1 and claudin-4, (iii) investigating the inhibitory action of $\alpha-\mathrm{MSH}$ on cytokineinduced inflammatory response, including NF- $\kappa$ B nuclear translocation, and polarized secretion of proinflammatory cytokines IL-6 and IL-8.

\section{Materials and Methods}

\section{Materials}

All reagents were purchased from Sigma-Aldrich Corporation (subsidiary of Merck KGaA, Darmstadt, Germany) unless otherwise indicated.

\section{Cell culture}

Human Caco-2 intestinal epithelial cells (\#86010202) purchased directly from European Collection of Authenticated Cell Cultures, UK, were cultured in Dulbecco's Minimum Essential Medium (DMEM) supplemented with 10\% fetal bovine serum [22]. Cell monolayers (10-40 passages) were grown on permeable polycarbonate inserts (Transwell ${ }^{\circledR}$, Corning, Lowell, MA, USA; $0.4 \mu \mathrm{m}$ pore size, $1.12 \mathrm{~cm}^{2}$ surface) in $\mathrm{CO}_{2}$ incubator at $37^{\circ} \mathrm{C}$. Cell seeding density was $2 \times 10^{5}$ cells/insert. Culture medium was replaced with fresh medium every two or three days. During the 21-day culture period Caco- 2 cells formed fully differentiated, confluent monolayers with apical-basal polarization. Differentiated and polarized cell layers showing high TEER values were used for experiments, as described in our previous study [23].

\section{Treatments}

To induce barrier damage differentiated Caco- 2 cell cultures were treated with a combination of the proinflammatory cytokines TNF- $\alpha(50 \mathrm{ng} / \mathrm{ml})$ and IL- $1 \beta(25 \mathrm{ng} / \mathrm{ml})$ for 24 hours. The control group received culture medium only (negative control). To test the protective effect of $\alpha$-MSH the following concentrations were used: $10^{-4} \mathrm{M}, 10^{-8} \mathrm{M}, 10^{-12} \mathrm{M}, 10^{-16} \mathrm{M}$.

\section{Measurement of transepithelial electrical resistance}

The formation of tight paracellular barrier in Caco-2 layers was monitored by the development of high transepithelial electrical resistance (TEER) and measured with Millicell-ERS volt-ohm meter (Millipore, USA) using chopstick electrodes. Resistance was expressed to the surface of the Transwell filters $\left(\Omega \times \mathrm{cm}^{2}\right)$ and the TEER of cell-free inserts was subtracted from these values.

\section{Measurement of permeability for marker molecules}

Cell culture inserts (surface: $0.33 \mathrm{~cm}^{2}$ ) containing confluent and differentiated Caco-2 cells were transferred to plates containing $530 \mu \mathrm{l}$ Ringer-Hepes buffer $(150 \mathrm{mM} \mathrm{NaCl}, 2.2 \mathrm{mM}$

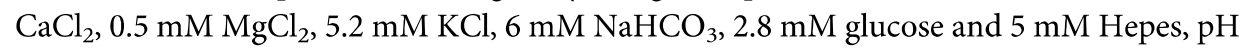
7.4 ) in the basal (lower) compartments. In the apical (upper) compartments culture medium was replaced by $70 \mu \mathrm{l}$ buffer containing albumin $(10 \mathrm{mg} / \mathrm{ml}$; Mw: $67 \mathrm{kDa})$ in complex with Evans blue $(167.5 \mu \mathrm{g} / \mathrm{ml})$ and sodium fluorescein $(10 \mu \mathrm{g} / \mathrm{ml}, \mathrm{Mw}$ : $376 \mathrm{Da})$. The plates were kept at $37^{\circ} \mathrm{C}$ in an incubator with $5 \% \mathrm{CO}_{2}$ for 1 hour on a rocking platform (100 rpm). After the incubation samples from the upper and lower compartments were collected and the concentrations of the marker molecules were determined by a fluorescence multiwell plate reader (Fluostar Optima, BMG Labtechnologies, Germany; excitation wavelength: $485 \mathrm{~nm}$, emission wavelength: $535 \mathrm{~nm}$ for fluorescein and excitation wavelength: $584 \mathrm{~nm}$, emission wavelength: $680 \mathrm{~nm}$ for Evans-blue labeled albumin). The apparent permeability coefficients $\left(\mathrm{P}_{\text {app }}\right)$ were 
calculated by the following equation [24].

$$
\mathrm{P}_{\text {app }}=\frac{[C]_{B} \times V_{B}}{A \times[C]_{A} \times t}
$$

where $[C]_{B}$ is the concentration of the tracer in the basal (acceptor) compartment after 1 hour, $[C]_{A}$ is the concentration of the tracer in the apical (donor) compartment at 0 hour, $V_{B}$ is the volume of the basal compartment $(530 \mu \mathrm{l})$ and $\mathrm{A}$ is the surface area available for permeability $\left(0.33 \mathrm{~cm}^{2}\right)$.

\section{Immunohistochemistry}

Melanocortin-1 receptor. Caco- 2 cell monolayers grown on polycarbonate filters were washed in phosphate buffered saline (PBS) and fixed with $4 \%$ paraformaldehyde solution for 20 minutes. Cell membranes were permeabilized with $0.2 \%$ Triton-X for 10 minutes. Non-specific binding sites were blocked with FBS for 30 minutes. A rabbit anti-human MC1R antibody (M9193 Sigma-Aldrich, AB_212630, $1 \mathrm{mg} / \mathrm{ml}$ ) was used for primary labelling of the target antigen, followed by secondary labelling with Alexa Fluor 488 conjugated to goat-anti-rabbit IgG (A-11008, Thermo Fisher Scientific, Waltham, MA, USA, AB_143165, $2 \mathrm{mg} / \mathrm{ml}$ ). Cell nuclei were labelled with propidium iodide. The samples were thoroughly washed with PBS after each step. Stainings were visualized by an Olympus FV1000 confocal microscope using an UPLSAPO 60× (NA 1.35) oil immersion objective. Excitation of Alexa Fluor 488 (conjugated to anti-MC1R) was accomplished using the 488 $\mathrm{nm}$ line of an Ar ion laser; with an emission spectrum of 500-530 nm. Excitation of propidium iodide was done using a $543 \mathrm{~nm}$ HeNe laser, with an emission spectrum of 555-635 nm. Excitation of Alexa Fluor 647 (labeling anti-MHC I W6/32 mAb) was done using a 633 $\mathrm{nm}$ HeNe laser, with an emission spectrum of $655-755 \mathrm{~nm}$. Line-by-line alternating illumination with the different lasers was used to minimize crosstalk. Images $(256 \times 256$-pixels; pixel size: $0.103 \mu \mathrm{m}$; pixel time: $4 \mu \mathrm{s}$ ) were collected and $4 \times$ averaging was applied to reduce background noise. Image stacks were recorded with a step size of $0.8 \mu \mathrm{m}$ and an optical slice thickness of $0.88 \mu \mathrm{m}$ (pinhole: $93 \mu \mathrm{m}$ ). Projection images of three adjacent optical sections were generated at the basal and at the apical side of the cells using the FV1000 software for the microscope. 3D image reconstructions of the cells were generated from image stacks. Transverse views of cells were used to visualize receptor expression levels of the apical and basal cell surfaces.

\section{ZO-1 and claudin-4 tight junction proteins and nuclear factor kappa B (NF-KB) activation}

For these experiments, Caco- 2 cells were seeded onto sterile uncoated microscope slides at a density of $5 \times 10^{4}$ cells/slide, and cultured until the formation of monolayers. Caco- 2 cultures were divided into three groups: the first group received culture medium only and served as negative controls. The second group was treated with IL- $1 \beta$ and TNF- $\alpha$; and the third group received $10^{-8} \mathrm{M} \alpha-\mathrm{MSH}$ in addition to cytokines. Treatments lasted 24 hours for the tight junction protein stainings, and for 30 minutes for p65 protein immunostaining, which is an indicator of NF- $\kappa$ B activation and nuclear localization. For ZO-1 and claudin-4 immunostainings cells were fixed and permeabilized with acetone/methanol 1:1. Primary staining was accomplished using rabbit anti-human ZO-1, or claudin-4 antibodies (40-2200 and PA516875, AB_2533456 and AB_10978522, $0.5 \mu \mathrm{g} / \mathrm{ml}$ ), followed by secondary labelling with Alexa Fluor 488 conjugated goat-anti-rabbit IgG (all antibodies from Thermo Fisher Scientific, MA USA). For p65 staining cells were fixed with ice-cold methanol-acetone ( $50 \mathrm{v} / \mathrm{v} \%)$ for 10 
minutes. Nonspecific antibody binding sites were blocked with FBS for 15 minutes. For primary labelling of NF- $\kappa$ B p 65 subunit rabbit anti-human p65 (sc-372, Santa Cruz Biotechnology, AB_632037, $100 \mu \mathrm{g} / \mathrm{ml}$ ) was used followed by secondary staining with Alexa Fluor 488-conjugated goat-anti-rabbit IgG and Hoechst 33342. For both TJ proteins and NF- $\kappa \mathrm{B}$ stainings samples were observed by Zeiss Axio Scope.A1 fluorescent microscope (HBO 100 lamp) (Carl Zeiss Microimaging GmbH, Göttingen, Germany). Images were analyzed with ZEN 2012 v.1.1.0.0. software (Carl Zeiss Microscopy GmbH, Göttingen, Germany), and for the NF- $\kappa \mathrm{B}$ stainings the ratio of nuclear and perinuclear fluorescence intensity was calculated. Specificity of all immunostainings was checked by incubating the cells with secondary antibodies only, and no background stainings were found.

\section{Flow cytometric bead array cytokine assay}

Production of the inflammatory cytokines IL- 6 and IL- 8 by Caco- 2 cells were measured in cell culture medium using the multiplexed flow cytometric bead array (CBA) Human Inflammatory Cytokines Kit (BD Biosciences, San Jose, CA, USA). For this assay $50 \mu \mathrm{l}$ culture medium samples were collected at 4 and 24 hours timepoints from the apical and basal compartments of culture inserts with confluent Caco- 2 monolayers treated with culture medium, cytokines and /or $\alpha-\mathrm{MSH}$. The CBA kits were used according to the manufacturer's instructions. The collected samples were diluted 2 times in the kit's assay buffer. Diluted samples or appropriate cytokine standards $(50 \mu \mathrm{l})$ were added to equal amounts of fluorescent cytokine capture bead suspension $(50 \mu \mathrm{l})$, and human inflammatory cytokine-phycoerythrin detection reagent $(50 \mu \mathrm{l})$ on multi-well filter microplates. The plates were incubated for 2 hours on a microplate shaker at room temperature, followed by washing with a vacuum filtration manifold. To each well $120 \mu \mathrm{l}$ assay buffer was added and cytokine content of each sample was measured by FACS array cytometry (BD Biosciences). Outcome data were analyzed using Flow Cytomix Pro 2.3 software.

\section{Statistical analysis}

For statistical analysis SigmaStat software (version 3.1; SPSS Inc.) and GraphPad Prism 5.0 software (GraphPad Software Inc., USA) were used. Data are presented as means \pm S.D. Comparison of groups was performed using ANOVA and Dunnett or Bonferroni tests.

Differences were considered significant at $P<0.05$.

\section{Results}

\section{Expression of melanocortin-1 receptor on Caco-2 cells}

MC1R expression was detectable on both the apical and basal membranes of differentiated Caco-2 cells in confluent monolayers by immunohistochemistry (Fig 1). The fluorescent immunolabeling was more pronounced on the apical side, as compared to the staining at the basal surface, where the red-stained cell nuclei were situated. This difference between the staining intensity was also visualized by the image of a horizontal section of a representative confluent Caco-2 cell monolayer.

\section{Effect of cytokines and $\alpha-\mathrm{MSH}$ on Caco-2 barrier integrity: transepithelial electrical resistance}

Differentiated Caco-2 monolayers expressed high TEER $\left(700 \Omega \times \mathrm{cm}^{2}, \mathrm{n}=24\right)$ indicating a tight paracellular barrier. Treatment with a combination of TNF- $\alpha$ and IL- $1 \beta$ cytokines decreased the resistance of Caco- 2 monolayers $(P<0.001$; Fig 2$)$. A concentration dependent 


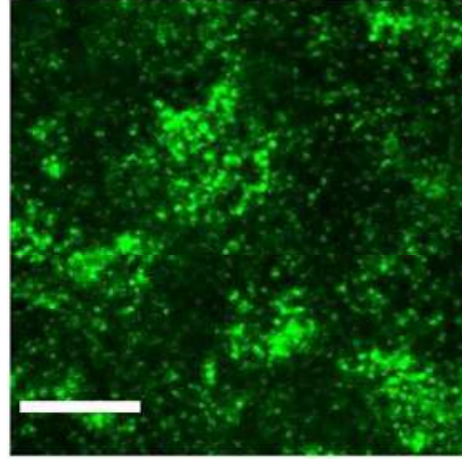

Apical surface

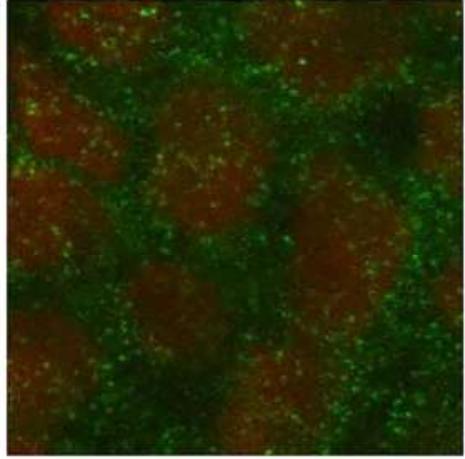

Basal surface

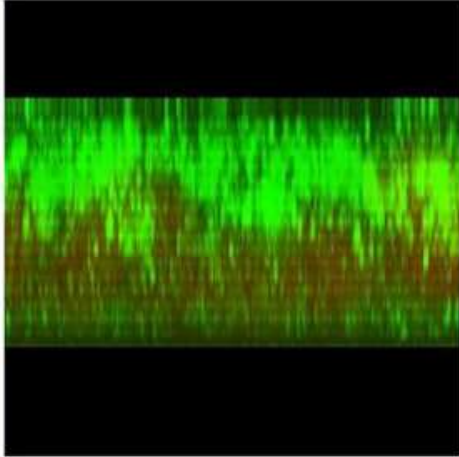

Horizontal section

Fig 1. Melanocortin-1 receptor (MC1R) expression in Caco-2 cells. Cells were grown into confluent monolayers for 21 days on culture inserts and immunostained for MC1R. Nuclei were labeled with propidium iodide. Optical sections prepared by a confocal microscope show MC1R expression levels at the apical and basal surfaces, and a digitized horizontal section of the cells. Green: MC1R labeling; red: cell nuclei. Scale bar: $5 \mu \mathrm{m}$.

doi:10.1371/journal.pone.0170537.g001

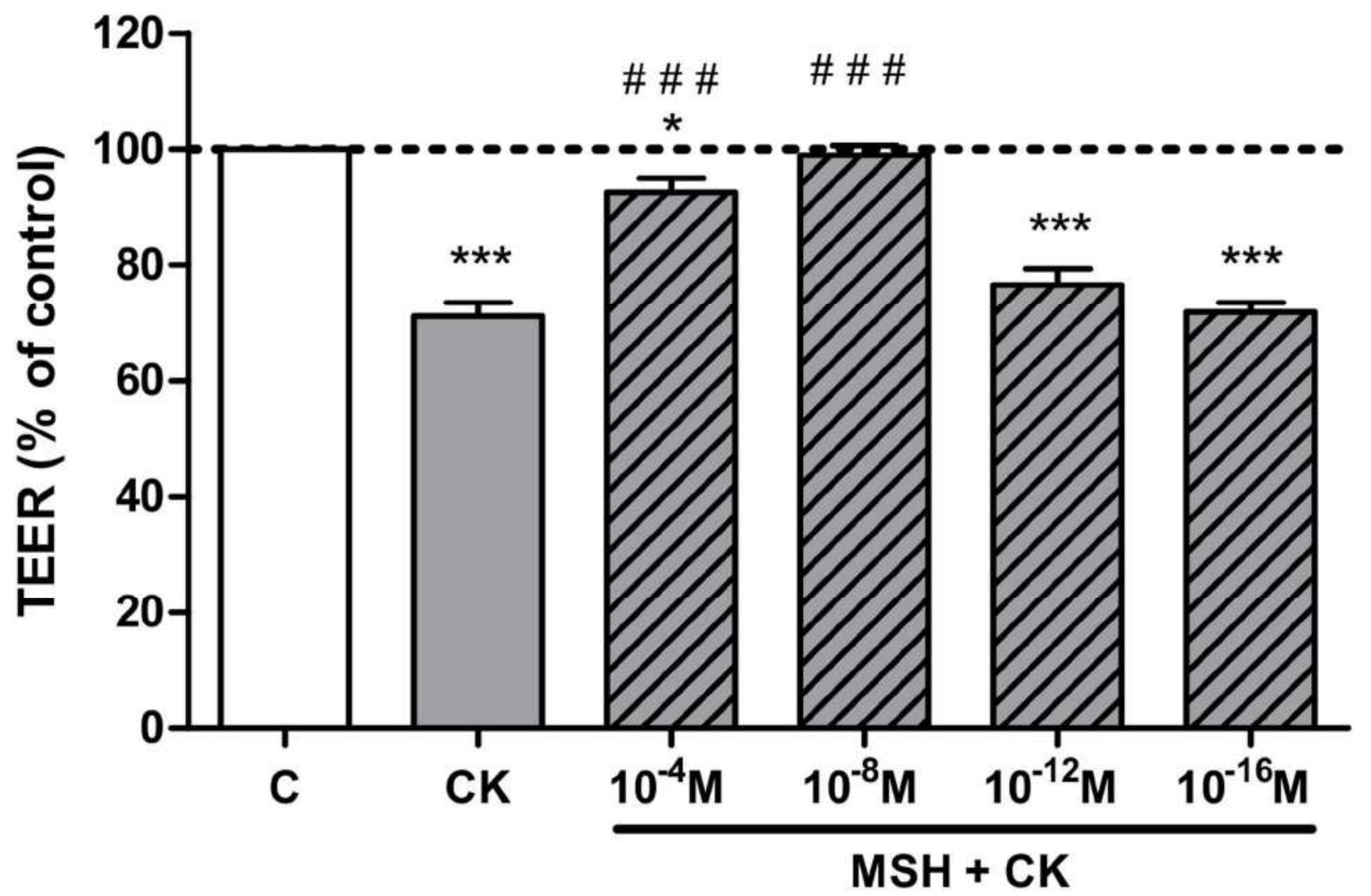

Fig 2. The effect of different concentrations of $\alpha-\mathrm{MSH}$ on the electrical resistance of cytokine treated Caco-2 monolayers. Caco-2 monolayers grown on culture inserts were treated with cytokines (CK; $50 \mathrm{ng} / \mathrm{ml}$ TNF- $\alpha$ and $25 \mathrm{ng} / \mathrm{ml}$ IL-1 3 ) without or with different concentrations of $\alpha-\mathrm{MSH}\left(10^{-4} \mathrm{M}, 10^{-8} \mathrm{M}, 10^{-12} \mathrm{M}\right.$, and $\left.10^{-16} \mathrm{M}\right)$ for 24 hours. The control group (C) received culture medium. Transepithelial electrical resistance (TEER) values are shown as percentage of untreated control. Means \pm S.D., $n=3 ;{ }^{* *} P<0.001$, ${ }^{*} P<0.05$, \#\#\# $P<0.001$. *: CK, CK+MSH compared to C; \#: CK+MSH compared to CK.

doi:10.1371/journal.pone.0170537.g002 
A

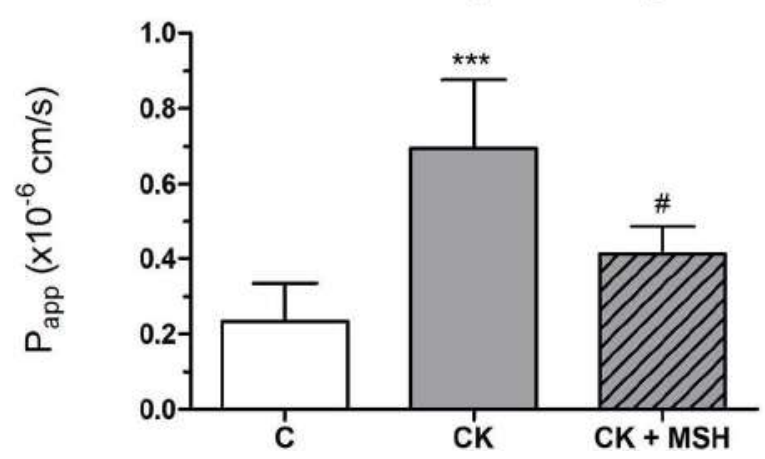

B

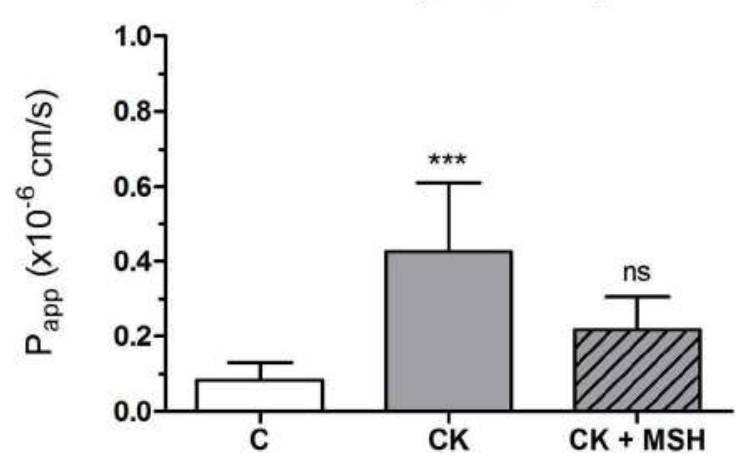

Fig 3. The effect of $\alpha-M S H$ treatment on the permeability of cytokine treated Caco-2 monolayers. Caco-2 monolayers grown on culture inserts were treated with cytokines (CK; $50 \mathrm{ng} / \mathrm{ml} \mathrm{TNF- \alpha} \mathrm{and} 25 \mathrm{ng} / \mathrm{ml} \mathrm{IL-1 \beta}$ ) without or with $\alpha-M S H\left(10^{-8} \mathrm{M}\right)$ for 24 hours, then permeability was measured for fluorescein $(A)$ and albumin $(B)$. The control group $(C)$ received culture medium. Means $\pm S . D ., n=4-6$; ${ }^{*} * P<0.001,{ }^{*} P<0.05$. $P_{\text {app }}$, apparent permeability coefficient. ${ }^{*}$ : CK, CK+MSH compared to C; ${ }^{\#}$ : CK+MSH compared to CK, ns: no significant difference to $\mathrm{C}$ or $\mathrm{CK}$.

doi:10.1371/journal.pone.0170537.g003

effect of $\alpha$-MSH was observed: the $10^{-4}$ and $10^{-8} \mathrm{M}$ concentrations of $\alpha$-MSH protected against the cytokine-induced barrier disruption $(P<0.001)$, while smaller concentrations had no effect. For further experiments the most effective, $10^{-8} \mathrm{M}$ concentration of $\alpha$-MSH was selected.

\section{Effect of cytokines and a-MSH on Caco-2 barrier integrity: permeability for marker molecules}

A low permeability for both small marker fluorescein $\left(1.71 \pm 0.17 \times 10^{-7} \mathrm{~cm} / \mathrm{s}\right)$ and large biomolecule albumin $\left(0.63 \pm 0.39 \times 10^{-7} \mathrm{~cm} / \mathrm{s}\right)$ was measured on the epithelial monolayers. Cytokine treatment significantly enhanced the permeability of the Caco-2 cell layers for both markers (Fig 3). The $\alpha$-MSH peptide $\left(10^{-8} \mathrm{M}\right)$ significantly blocked the barrier opening effect of the cytokines for fluorescein.

\section{Effect of cytokines and $\alpha-\mathrm{MSH}$ on Caco-2 barrier integrity: localization of TJ proteins ZO-1 and claudin-4 by immunofluorescence microscopy}

The tight paracellular barrier of Caco-2 cells was also demonstrated by the localization of integral membrane TJ protein claudin-4 and cytoplasmic linker protein $\mathrm{ZO}-1$, which appeared at the cell-cell borders in a continuous, belt-like manner (Fig 4). In the control group cell-cell attachment in the monolayers was continuous, without gaps. In cytokine treated cells the pattern of the staining changed: intercellular gaps, fragmented junctional staining and cytoplasmic redistribution of junctional proteins were observed. The immunostaining pattern of TJ proteins in epithelial cells treated with $\alpha-\mathrm{MSH}$ was similar to the control group.

\section{Effect of $\alpha-\mathrm{MSH}$ on cytokine-induced NF-kB nuclear translocation in Caco-2 cells}

Translocation of the p65 NF- $\mathrm{BB}$ subunit into cell nuclei is a reliable measure of the intensity of an inflammatory reaction at the cellular level. To further analyze the potential effects of $\alpha$ MSH early NF- $\mathrm{KB}$ nuclear translocation was investigated in Caco-2 cells following short term (30 minutes) cytokine treatment (Fig 5A). Inflammatory cytokines induced the appearance of green-stained $\mathrm{p} 65$ within nuclei of Caco- 2 cells. The nucleus/cytosol intensity ratios of green 


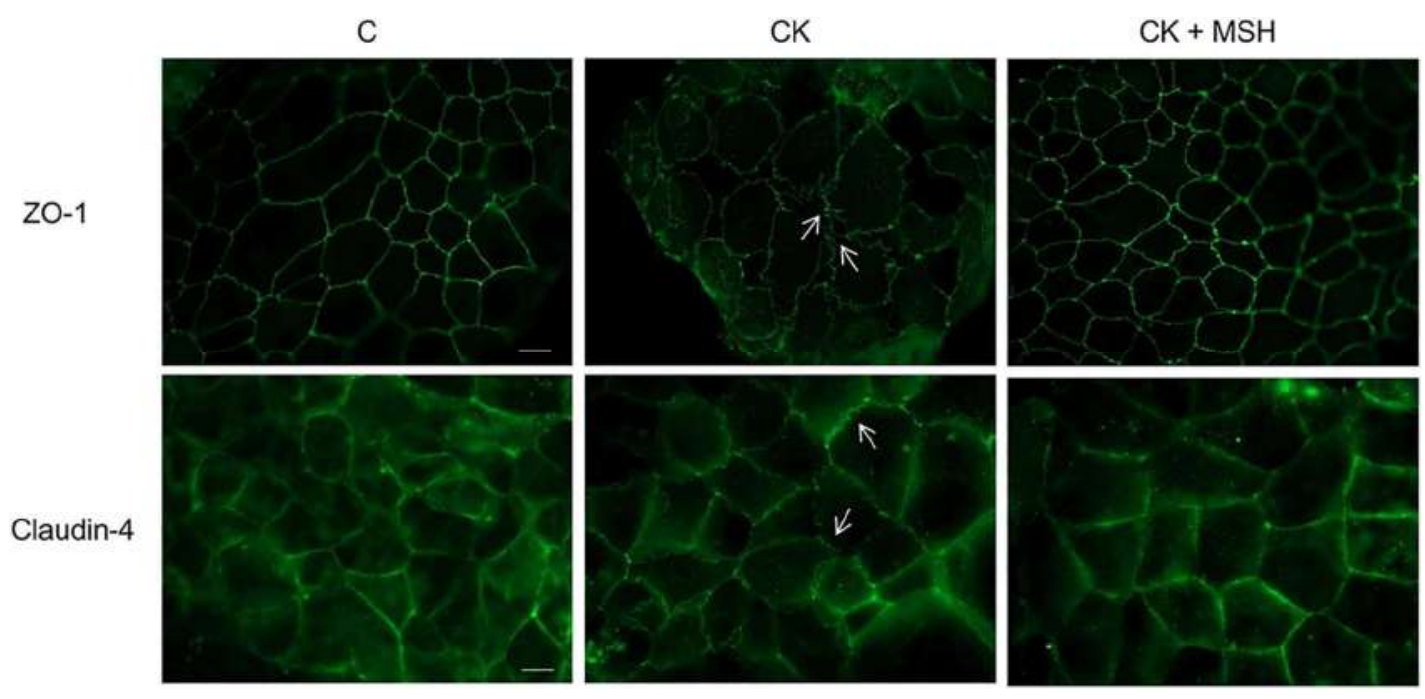

Fig 4. The effect of $\alpha-M S H$ treatment on the immunostaining of tight juntion proteins claudin- 4 and ZO-1 in cytokine treated Caco-2 cells. Caco-2 cells were treated with cytokines (CK; $50 \mathrm{ng} / \mathrm{ml}$ TNF- $\alpha$ and $25 \mathrm{ng} / \mathrm{ml} \mathrm{IL}-1 \beta$ ) without or with $10^{-8} \mathrm{M} \mathrm{a-MSH}(\mathrm{CK}+\mathrm{MSH})$ for 24 hours, then immunostained for integral membrane tight junction protein claudin-4 and cytoplasmic linker protein ZO-1. The control group (C) received culture medium. The fluorescent microscopy images demonstrate the expression and organization of the junctional proteins. Scale bar: $10 \mu \mathrm{m}$.

doi:10.1371/journal.pone.0170537.g004

channel fluorescence provide a numerical display of the cytokine effect [25] with low ratios corresponding to control cells. The increased ratio of signal intensity, combined with co-localization of green and blue signals, reflects inflammatory cytokine-mediated nuclear translocation of p65. The NF- $\mathrm{BB}$ nuclear translocation indicated by high nucleus/cytoplasm intensity ratio observed after cytokine treatment was significantly inhibited by $10^{-8} \mathrm{M} \alpha-\mathrm{MSH}$ (Fig $5 \mathrm{~B}$ ).

A
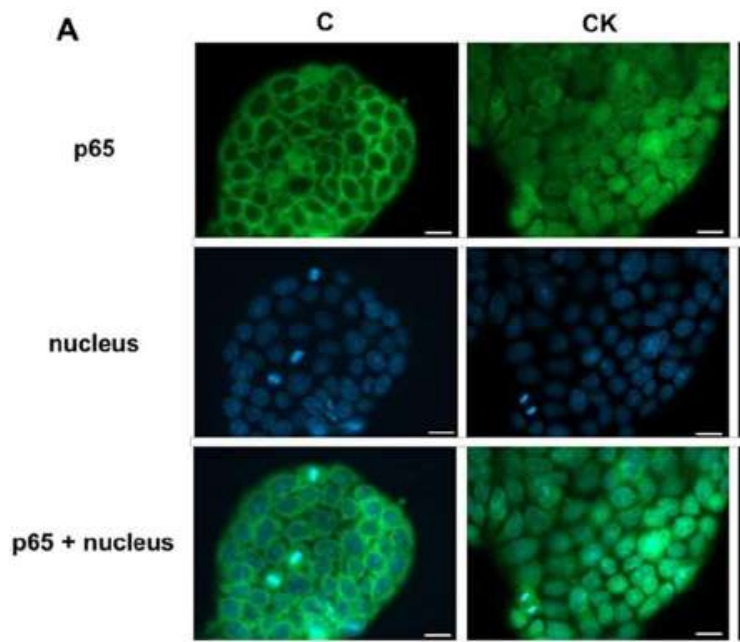

$\mathrm{CK}+\mathrm{MSH}$
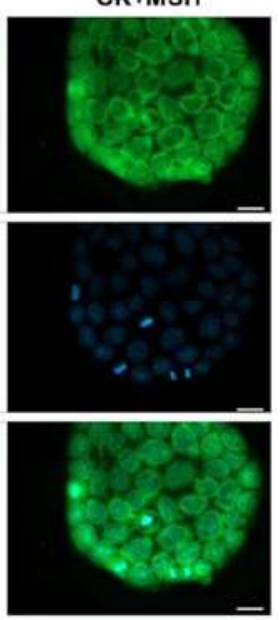

B

\section{Nucleus/cytosol intensity}

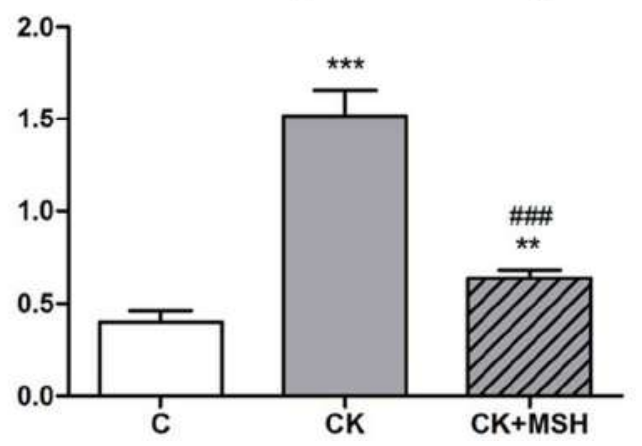

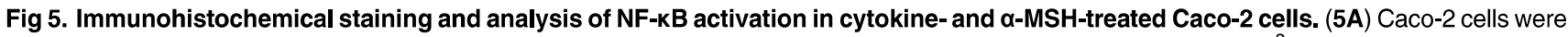
treated for 30 minutes with culture medium (C), cytokines (CK; $50 \mathrm{ng} / \mathrm{ml} \mathrm{TNF- \alpha} \mathrm{and} 25 \mathrm{ng} / \mathrm{ml} \mathrm{IL-1 \beta}$ ), or cytokines and $10^{-8} \mathrm{M} \alpha-M S H(C K+M S H)$. Nuclear localization of the NF-KB p65 subunit was monitored by immunostaining. Cell nuclei were labeled with Hoechst 33342 . Green: p65 staining; blue: cell nuclei. Scale bar: $10 \mu \mathrm{m}$. (5B) Ratio of the fluorescence intensity of the NF-KB immunostaining in cell nuclei and cytoplasm. Means \pm S.D., $\mathrm{n}=8-10,{ }^{* * *} P<0.001,{ }^{*} P<0.01, \# \# \# P<0.001$. * $\mathrm{CK}, \mathrm{CK}+\mathrm{MSH}$ compared to $\mathrm{C} ; \#: \mathrm{CK}+\mathrm{MSH}$ compared to $\mathrm{CK}$.

doi:10.1371/journal.pone.0170537.g005 
A

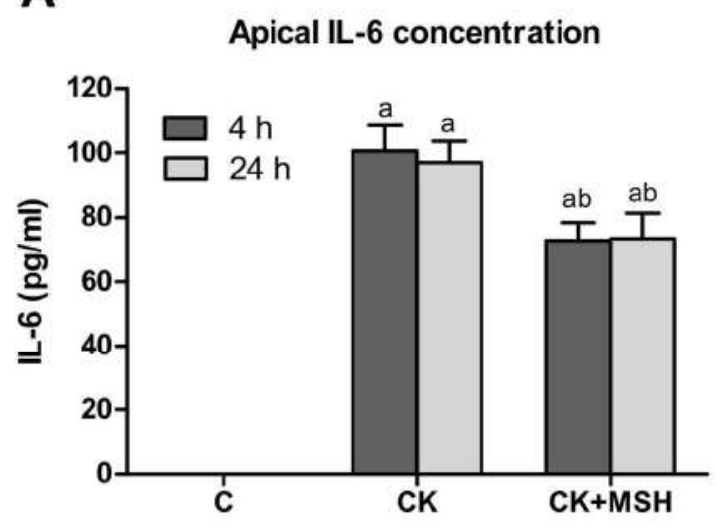

C

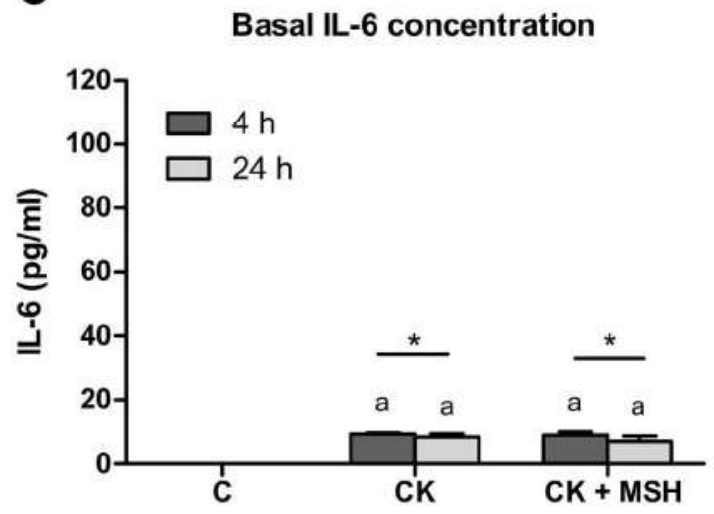

B

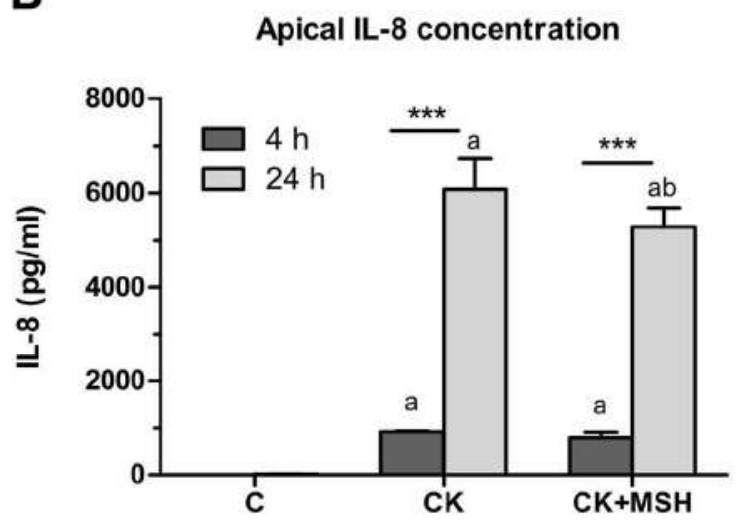

D

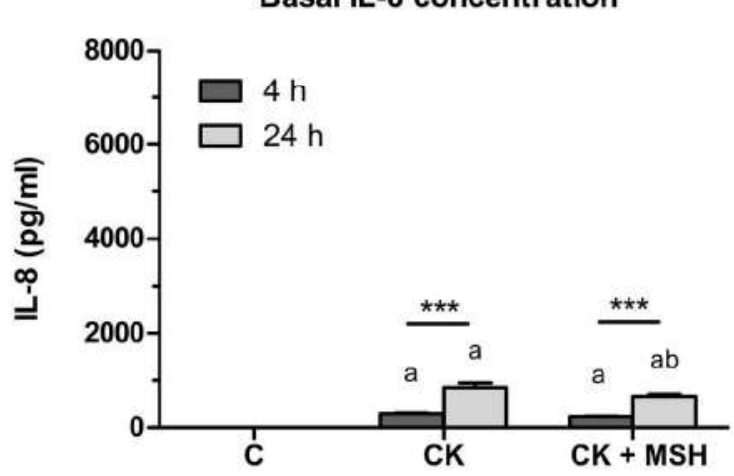

Fig 6. Secretion of IL-6 and IL-8 in Caco-2 cells treated with cytokines and $\alpha-\mathrm{MSH}$. Caco-2 monolayers grown on culture inserts were treated with cytokines (CK; $50 \mathrm{ng} / \mathrm{ml} \mathrm{TNF- \alpha} \mathrm{and} 25 \mathrm{ng} / \mathrm{ml} \mathrm{IL-1 \beta}$ ) without or with $\alpha-\mathrm{MSH}\left(10^{-8} \mathrm{M}\right)$ for 4 and 24 hours. The control group (C) received culture medium. Culture medium samples were collected from the apical and basal compartments. The concentration of IL-6 (6A and $6 \mathrm{C}$ ) and IL-8 (6B and $6 \mathrm{D})$ secreted by Caco-2 cells were measured by multiplexed flow cytometric bead array assays. Means \pm S.D., $\mathrm{n}=3-5,{ }^{* *} P<0.001,{ }^{*} P<0.05$; a: CK, CK+MSH compared to C, $P<0.001$; b: CK+MSH compared to CK, $P<0.001[1]$.

doi:10.1371/journal.pone.0170537.g006

\section{Effect of cytokines and $\alpha-\mathrm{MSH}$ on polarized release of IL- 6 and IL-8 from Caco- 2 cells}

In comparison to unstimulated control cultures, cytokine treatment resulted in significant elevation of IL- 6 release into the apical compartments, along with significant $\alpha$-MSH-dependent suppression of this effect $(P<0.001)$ at both 4 - and 24-hour time points (Fig 6A). No statistical difference was observed in cytokine expression increase, or in $\alpha-\mathrm{MSH}$-mediated inhibition of this increase between the 4- and 24-hour measurements (Fig 6A). Apical cytokine-induced release of IL- 8 increased significantly at both time points relative to the control group, but IL- 8 production measured in medium samples collected apically at the 24-hour time point was elevated more than 5 -fold $(P<0.001)$ relative to that at 4 hours $($ Fig $6 \mathrm{~B})$, but $\alpha-\mathrm{MSH}$ had no effect (Fig 6B). Cytokine-induced release of IL-6 and IL-8 into the basal compartments occurred according to a somewhat different pattern from that of the apical medium: although IL- 6 release to the basal compartment significantly exceeded that of untreated control cultures $(P<0.05)($ Fig $6 \mathrm{C})$, with no significant difference noted between the 4 - and 24-hour time points, $\alpha$-MSH treatment failed to suppress the basolateral release of IL-6 (Fig 6C). Similarly to 
apical IL- 8 expression responses, cytokine-induced production of IL- 8 by Caco- 2 monolayers measured from the basal compartments was significantly increased relative to control cells at both the 4-hour and 24-hour time points, but significantly greater at 24 hours $(P<0.001)$ (Fig $6 \mathrm{D}) . \alpha-\mathrm{MSH}$ treatment significantly reduced IL- 8 expression at 24 -hour time points $(P<0.001)($ Fig 6D).

\section{Discussion}

The goal of the present study was to evaluate the protective effect of $\alpha-\mathrm{MSH}$ on proinflammatory cytokine-induced Caco- 2 monolayer activation and barrier injury.

We demonstrated the polarized expression of MC1R on human Caco-2 epithelial cells with a predominant apical localization (Fig 1) for the first time. Our results are in agreement with the data of Maaser et al. who described the constitutive expression of MC1R protein in mouse intestinal epithelial cells [21]. The presence of this receptor provides the basis for the hypothesized direct action of $\alpha-\mathrm{MSH}$ on epithelial cells.

A combination of the two most important pro-inflammatory cytokines in gut diseases opened the paracellular barrier in Caco-2 monolayers for both ions measured by TEER (Fig 2) and marker molecules fluorescein and albumin (Fig 3 ) indicating that there is a barrier leakage for large biomolecules, too. The concentrations of TNF- $\alpha$ and IL- $1 \beta$ were proven to induce barrier damage in Caco- 2 cells in previous studies $[10,8]$. We observed a protective effect of $\alpha$ $\mathrm{MSH}$ against cytokine-induced resistance decrease with a maximal effect at the concentration of $10^{-8} \mathrm{M}$. This concentration of $\alpha-\mathrm{MSH}$ is similar to the concentrations which proved to be effective on other cell types $[\underline{14}, \underline{26}]$ and in animal experiments $[\underline{19}, 27, \underline{28}]$. The $10^{-8} \mathrm{M}$ concentration of $\alpha-\mathrm{MSH}$ we found the most effective corresponds to the physiological plasma concentration of the hormone in humans [29] and in newborn pigs [30]. We also found, that $\alpha-\mathrm{MSH}-$ mediated barrier protection is not directly proportional to concentration of the hormone. It was demonstrated earlier that $\alpha-\mathrm{MSH}$, like other peptide hormones, can show bell-shape doseresponse curve [31] similarly to our findings. The $\alpha-\mathrm{MSH}$ concentration that prevented the drop in TEER was also protective against paracellular barrier opening for fluorescein (Fig 3 ). Data showing that an $\alpha$-MSH related tripeptide blocked the reduced TEER induced by cytokines on T84 monolayers, another human intestinal cell line, supports our findings [ㄹ].

Since TJ proteins seal the intercellular gaps in epithelial barriers, the disruption of Caco-2 monolayers was also reflected at the level of cell-cell interactions. Two membrane-associated TJ proteins, ZO-1 and claudin-4, were used as representative TJ components. In concordance with the functional measurements of barrier opening, cytokine treatment caused a decreased immunostaining at cellular borders, where punctate and discontinuous staining was observed (Fig 4). In our previous work we also demonstrated morphological changes at cellular junctions in parallel with opening of the paracellular cleft in Caco- 2 cells by TJ modulator peptides [12]. In agreement with our observations claudin- 4 was described to promote barrier function in different cell cultures, and proinflammatory cytokines decreased its junctional presence and increased the proportion of mobile claudin -4 in the TJ of Caco- 2 cells $[33,34]$. Importantly, claudin-4 expression is downregulated in intestinal biopsies of patients with ulcerative colitis [35], indicating the potential clinical significance of the experimental observations.

The mechanisms that mediate the effect of the proinflammatory cytokines TNF- $\alpha$ and IL$1 \beta$ on intestinal barrier functions are well studied $[\underline{7,9}, \underline{36}]$. Earlier investigations verified that TNF- $\alpha$-induced increase in Caco- 2 TJ permeability is associated with downregulation of ZO-1 protein expression and alteration in ZO-1 junctional localization. This intracellular process is mediated by NF- $\kappa B$ activation [36]. IL- $1 \beta$ also causes NF- $\kappa B$ activation in Caco- 2 cells leading to increased MLCK mRNA and protein expression resulting in elevated junctional 
permeability [9]. The role of the NF- $\kappa B-M L C K$ pathway was also demonstrated in TNF- $\alpha$ induced TJ opening in Caco-2 monolayers [37]. In the presence of $\alpha-\mathrm{MSH}$ we found that the damaging effect of cytokines on TJ morphology was attenuated. Our data are supported by another study where $\alpha$-MSH prevented the cytokine-induced redistribution of TJ proteins and the opening of the barrier by NF- $\kappa B$ inhibition [14]

Translocation of the NF- $\mathrm{BB}$ p 65 subunit into cell nuclei is a key event in inflammatory reactions and epithelial barrier opening at the level of signaling pathways $[\underline{8}, \underline{38}, \underline{39}]$. We could confirm in our study that cytokine treatments induced NF- $\kappa$ B nuclear translocation in Caco-2 epithelial cells, which was inhibited by $\alpha$-MSH (Fig 5). These results further strengthen the role of $\alpha \mathrm{MSH}$ as a potent antiinflammatory molecule $[5,14]$ which exerts its effect by inhibition of the NF- $\kappa B$ transcription factor. Indeed, NF- $\kappa B$ inhibition was found to be central in the protective effect of $\alpha-\mathrm{MSH}$ against oxidative stress in IEC- 6 rat intestinal cells [40] and against ischemia/reperfusion induced intestinal injury in rats $[\underline{19}, \underline{20}]$.

As a downstream effect of NF- $\kappa \mathrm{B}$ activation epithelial cells can secrete cytokines in inflammatory conditions further exacerbating gut barrier injury [20]. We found elevated secretion of IL-6 and IL-8 inflammatory cytokines in Caco- 2 cells treated with TNF- $\alpha$ and IL-1 $\beta$ (Fig 6 ). The increased expression of these cytokines was also described in both cultured intestinal cells after inflammatory stimulation $[\underline{5}, \underline{6}, \underline{8}]$ and in a rat model of intestinal injury [리 $]$. We observed that the cytokine-induced IL- 6 and IL-8 production was vectorial, with significantly greater apical secretion. The differences between apical and basal IL- 6 and IL- 8 release from Caco- 2 cells are consistent with the results of other investigators $[11,5]$. Treatment with $\alpha-\mathrm{MSH}$ inhibited the apical secretion of IL- 6 and the basal release of IL-8. Other studies also support this inhibitory action of $\alpha-\mathrm{MSH}$. KPV, an $\alpha-\mathrm{MSH}$ related tripeptide, reduced IL8 expression in Caco-2-BBE cells stimulated by IL-1 $\beta$ []] or LPS [] ]. Notably, KPV and KdPT tripeptides derived from $\alpha-\mathrm{MSH}$ were protective not only on injured Caco- 2 cultures, but also in mouse and rat models of colitis [32,6]. Importantly, $\alpha-\mathrm{MSH}$ also blocked IL-6 protein expression in rat intestinal injury concomitantly with its protective effect [20] underlying the potential therapeutical significance of our findings.

In conclusion, the direct protective effect of $\alpha-\mathrm{MSH}$ on pro-inflammatory cytokine induced barrier dysfunction and inflammatory activation in Caco-2 monolayers was investigated for the first time in this study. We demonstrated the presence of major $\alpha-\mathrm{MSH}$ receptor $\mathrm{MC} 1$ on Caco-2 epithelial cells, and a protective effect of the antiinflammatory hormone on TNF- $\alpha$ and IL-1 $\beta$ treatment induced paracellular barrier opening in parallel with the inhibition of NF- $\mathrm{KB}$ nuclear translocation and polarized secretion of other inflammatory cytokines. These findings support the therapeutical potential of $\alpha-\mathrm{MSH}$ to restore epithelial barrier integrity in inflammatory gut diseases.

\section{Acknowledgments}

The authors confirm that there are no conflicts of interest with respect to any of the topic material presented herein.

\section{Author Contributions}

Conceptualization: MV JV FF.

Data curation: KR-N AH MD JV.

Formal analysis: KR-N JV PG AH PF ZU.

Funding acquisition: MD MV FF. 
Investigation: JV FF PG G. Vámosi G. Vasvári AH.

Methodology: JV FF AH.

Project administration: JV MV IB.

Resources: G. Vasvári IB MD.

Supervision: FF MD JV.

Validation: MD AH JV ER.

Visualization: AH JV G. Vámosi.

Writing - original draft: FF JV DH.

Writing - review \& editing: MD MV JV FF AH.

\section{References}

1. Lee $\mathrm{SH}$. Intestinal permeability regulation by tight junction: implication on inflammatory bowel diseases. Intest Res. 2015 Jan; 13(1):11-8. doi: 10.5217/ir.2015.13.1.11 PMID: 25691839

2. Artursson $P, P a l m K$, Luthman K. Caco-2 monolayers in experimental and theoretical predictions of drug transport. Adv Drug Deliv Rev. 2001 Mar 1; 46(1-3):27-43. PMID: 11259831

3. Sambuy Y, De Angelis I, Ranaldi G, Scarino ML, Stammati A, Zucco F. The Caco-2 cell line as a model of the intestinal barrier: influence of cell and culture-related factors on Caco-2 cell functional characteristics. Cell Biol Toxicol. 2005; 21(1):1-26. doi: 10.1007/s10565-005-0085-6 PMID: 15868485

4. Susewind J, de Souza Carvalho-Wodarz C, Repnik U, Collnot EM, Schneider-Daum N, Griffiths GW, et al. A 3D co-culture of three human cell lines to model the inflamed intestinal mucosa for safety testing of nanomaterials. Nanotoxicology. 2015:1-10.

5. Dalmasso G, Charrier-Hisamuddin L, Nguyen HT, Yan Y, Sitaraman S, Merlin D. PepT1-mediated tripeptide KPV uptake reduces intestinal inflammation. Gastroenterology. 2008; 134(1):166-78. doi: 10. 1053/i.gastro.2007.10.026 PMID: 18061177

6. Laroui H, Dalmasso G, Nguyen HT, Yan Y, Sitaraman SV, Merlin D. Drug-loaded nanoparticles targeted to the colon with polysaccharide hydrogel reduce colitis in a mouse model. Gastroenterology. 2010 Mar; 138(3):843-53.e1-2. doi: 10.1053/j.gastro.2009.11.003 PMID: 19909746

7. Al-Sadi R, Ye D, Said HM, Ma TY. IL-1beta-induced increase in intestinal epithelial tight junction permeability is mediated by MEKK-1 activation of canonical NF-KB pathway. Am J Pathol. 2010; 177(5):231022. doi: 10.2353 /ajpath.2010.100371 PMID: 21048223

8. Van De Walle J, Hendrickx A, Romier B, Larondelle Y, Schneider YJ. Inflammatory parameters in Caco-2 cells: effect of stimuli nature, concentration, combination and cell differentiation. Toxicol In Vitro. 2010; 24(5):1441-9. doi: 10.1016/j.tiv.2010.04.002 PMID: 20406675

9. Al-Sadi R, Guo S, Dokladny K, Smith MA, Ye D, Kaza A, et al. Mechanism of interleukin-1 $\beta$ inducedincrease in mouse intestinal permeability in vivo. J Interferon Cytokine Res. 2012; 32(10):474-84. doi: 10.1089/jir.2012.0031 PMID: 22817402

10. Ramadan $Q$, Jing $L$. Characterization of tight junction disruption and immune response modulation in a miniaturized Caco-2/U937 coculture-based in vitro model of the human intestinal barrier. Biomed Microdevices. 2016; 18(1).

11. Sonnier DI, Bailey SR, Schuster RM, Lentsch AB, Pritts TA. TNF- $\alpha$ induces vectorial secretion of IL-8 in Caco-2 cells. J Gastrointest Surg. 2010; 14(10):1592-9. doi: 10.1007/s11605-010-1321-9 PMID: 20827577

12. Bocsik A, Walter FR, Gyebrovszki A, Fülöp L, Blasig I, Dabrowski S, et al. Reversible opening of intercellular junctions of intestinal epithelial and brain endothelial cells with tight junction modulator peptides. J Pharm Sci. 2016 Feb; 105(2):754-65. doi: 10.1016/j.xphs.2015.11.018 PMID: 26869428

13. Lin JE, Snook AE, Li P, Stoecker BA, Kim GW, Magee MS, et al. GUCY2C opposes systemic genotoxic tumorigenesis by regulating AKT-dependent intestinal barrier integrity. PLoS One. 2012; 7(2):e31686. doi: 10.1371/journal.pone.0031686 PMID: 22384056

14. Kalden DH, Scholzen T, Brzoska T, Luger TA. Mechanisms of the antiinflammatory effects of $\alpha-M S H$. Role of transcription factor NF-KB and adhesion molecule expression. Ann N Y Acad Sci. 1999; 885:254-61 PMID: $\underline{10816658}$ 
15. Luger TA, Brzoska T. Alpha-MSH related peptides: a new class of anti-inflammatory and immunomodulating drugs. Ann Rheum Dis. 2007; 66 Suppl 3:iii52-5.

16. Brzoska T, Luger TA, Maaser C, Abels C, Böhm M. Alpha-melanocyte-stimulating hormone and related tripeptides: biochemistry, antiinflammatory and protective effects in vitro and in vivo, and future perspectives for the treatment of immune-mediated inflammatory diseases. Endocr Rev. 2008; 29(5):581602. doi: 10.1210/er.2007-0027 PMID: 18612139

17. Rajora N, Boccoli G, Catania A, Lipton JM. Alpha-MSH modulates experimental inflammatory bowel disease. Peptides. 1997; 18(3):381-5. PMID: 9145424

18. Oktar BK, Ercan F, Yegen BC, Alican I. The effect of $\alpha$-melanocyte stimulating hormone on colonic inflammation in the rat. Peptides. 2000; 21(8):1271-7. PMID: 11035215

19. Hassoun HT, Zou L, Moore FA, Kozar RA, Weisbrodt NW, Kone BC. Alpha-melanocyte-stimulating hormone protects against mesenteric ischemia-reperfusion injury. Am J Physiol Gastrointest Liver Physiol. 2002 Jun; 282(6):G1059-68 doi: 10.1152/ajpgi.00073.2001 PMID: 12016132

20. Zou L, Sato N, Attuwaybi BO, Kone BC. Delayed administration of a-melanocyte-stimulating hormone or combined therapy with BAY 11-7085protects against gut ischemia-reperfusion injury. Shock. 2003 Nov; 20(5):469-75. doi: 10.1097/01.shk.0000091205.08003.fd PMID: 14560113

21. Maaser C, Kannengiesser K, Specht C, Lügering A, Brzoska T, Luger TA, et al. Crucial role of the melanocortin receptor MC1R in experimental colitis. Gut. 2006 Oct; 55(10):1415-22. doi: 10.1136/gut.2005. 083634 PMID: 16543288

22. Kiss T, Fenyvesi F, Bácskay I, Váradi J, Fenyvesi E, Iványi R, et al. Evaluation of the cytotoxicity of $\beta$ cyclodextrin derivatives: evidence for the role of cholesterol extraction. Eur J Pharm Sci. 2010 Jul 11; 40 (4):376-80. doi: 10.1016/j.ejps.2010.04.014 PMID: 20434542

23. Fenyvesi F, Kiss T, Fenyvesi E, Szente L, Veszelka S, Deli MA, et al. Randomly methylated beta-cyclodextrin derivatives enhance taxol permeability through human intestinal epithelial Caco-2 cell monolayer. J Pharm Sci. 2011; 100(11):4734-44. doi: 10.1002/jps.22666 PMID: 21660974

24. Kürti L, Veszelka S, Bocsik A, Ózsvári B, Puskás LG, Kittel A, et al. Retinoic acid and hydrocortisone strengthen the barrier function of human RPMI 2650 cells, a model for nasal epithelial permeability. Cytotechnology. 2013; 65(3):395-406. doi: 10.1007/s10616-012-9493-7 PMID: 22940916

25. Mako V, Czucz J, Weiszhar Z, Herczenik E, Matko J, Prohaszka Z, et al. Proinflammatory activation pattern of human umbilical vein endothelial cells induced by IL-1 $\beta$, TNF- $\alpha$, and LPS. Cytometry A. 2010; 77(10):962-70. doi: 10.1002/cyto.a.20952 PMID: 21290470

26. Bijuklic K, Jennings $P$, Kountchev J, Hasslacher J, Aydin S, Sturn D, et al. Migration of leukocytes across an endothelium-epithelium bilayer as a model of renal interstitial inflammation. J Physiol Cell Physiol. 2007 Jul; 293(1):C486-92.

27. Vecsernyes $M$, Juhasz B, Der $P$, Kocsan $R$, Feher $P$, Bacskay I, et al. The administration of $\alpha-$ melanocyte-stimulating hormone protects the ischemic/reperfused myocardium. Eur J Pharmacol. 2003 Jun 6; 470(3):177-83. PMID: 12798956

28. Varga B, Gesztelyi R, Bombicz M, Haines D, Szabo AM, Kemeny-Beke A, et al. Protective effect of $\alpha$ melanocyte-stimulating hormone $(\alpha-M S H)$ on the recovery of ischemia/reperfusion $(\mathrm{l} / \mathrm{R})$-induced retinal damage in a rat model. J Mol Neurosci. 2013 Jul; 50(3):558-70. doi: 10.1007/s12031-013-9998-3 PMID: 23504281

29. Magnoni S, Stocchetti N, Colombo G, Carlin A, Colombo A, Lipton JM, et al. Alpha-melanocyte-stimulating hormone is decreased in plasma of patients with acute brain injury. J Neurotrauma. 2003 Mar; 20 (3):251-60. doi: 10.1089/089771503321532833 PMID: 12820679

30. Kovács J, Julesz J, Mogyoróssy MV, Deli MA, Abrahám CS, Vecsernyés M. Asphyxia-induced release of $\alpha$-melanocyte-stimulating hormone in newborn pigs. Peptides. $2001 \mathrm{Jul}$; 22(7):1049-53. PMID: 11445233

31. Joosten EA, Verhaagh S, Martin D, Robe P, Franzen R, Hooiveld M, et al. Alpha-MSH stimulates neurite outgrowth of neonatal rat corticospinal neurons in vitro. Brain Res. 1996 Oct 14; 736(1-2):91-8. PMID: 8930313

32. Bettenworth D, Buyse M, Böhm M, Mennigen R, Czorniak I, Kannengiesser K, et al. The tripeptide KdPT protects from intestinal inflammation and maintains intestinal barrier function. Am J Pathol. 2011 Sep; 179(3):1230-42. doi: 10.1016/j.ajpath.2011.05.013 PMID: 21741932

33. Wang J, Lopez-Fraga M, Rynko A, Lo DD. TNFR and LT $\beta R$ agonists induce follicle-associated epithelium and $M$ cell specific genes in rat and human intestinal epithelial cells. Cytokine. 2009 Jul; 47(1):6976. doi: $\underline{10.1016 / \text { i.cyto.2009.05.001 PMID: } 19501526}$

34. Capaldo CT, Farkas AE, Hilgarth RS, Krug SM, Wolf MF, Benedik JK, et al. Proinflammatory cytokineinduced tight junction remodeling through dynamic self-assembly of claudins. Mol Biol Cell. 2014 Sep 15; 25(18):2710-9. doi: 10.1091/mbc.E14-02-0773 PMID: 25031428 
35. Oshima T, Miwa H, Joh T. Changes in the expression of claudins in active ulcerative colitis. J Gastroenterol Hepatol. 2008 Dec; 23 Suppl 2:S146-50.

36. Al-Sadi R, Guo S, Ye D, Ma TY. TNF-a modulation of intestinal epithelial tight junction barrier is regulated by ERK1/2 activation of Elk-1. Am J Pathol. 2013; 183(6):1871-84. doi: 10.1016/j.ajpath.2013.09. $\underline{001}$ PMID: $\underline{24121020}$

37. Ye D, Ma I, Ma TY. Molecular mechanism of tumor necrosis factor- $\alpha$ modulation of intestinal epithelial tight junction barrier. Am J Physiol Gastrointest Liver Physiol. 2006; 290(3):G496-504. doi: 10.1152/ ajpgi.00318.2005 PMID: 16474009

38. Choi HJ, Kim J, Park SH, Do KH, Yang H, Moon Y. Pro-inflammatory NF-KB and early growth response gene 1 regulate epithelial barrier disruption by food additive carrageenan in human intestinal epithelial cells. Toxicol Lett. 2012 Jun 20; 211(3):289-95. doi: 10.1016/j.toxlet.2012.04.012 PMID: 22561171

39. Wang L, Walia B, Evans J, Gewirtz AT, Merlin D, Sitaraman SV. IL-6 induces NF-KB activation in the intestinal epithelia. Journal of immunology. 2003; 171(6):3194-201.

40. Zou L, Sato N, Kone BC. Alpha-melanocyte stimulating hormone protects against $\mathrm{H}_{2} \mathrm{O}_{2}$-induced inhibition of wound restitution in IEC- 6 cells via a Syk kinase- and NF-KB-dependent mechanism. Shock. 2004 Nov; 22(5):453-9. PMID: 15489638 
II. publikáció 


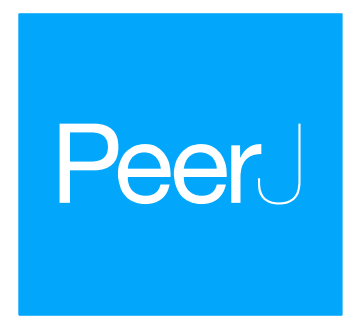

Submitted 21 February 2018

Accepted 23 April 2018

Published 15 May 2018

Corresponding authors

Maria A. Deli,

deli.maria@brc.mta.hu

Miklós Vecsernyés,

vecsernyes.miklos@

pharm.unideb.hu

Academic editor

Elena González-Burgos

Additional Information and Declarations can be found on page 17

DOI 10.7717/peerj.4774

(C) Copyright

2018 Harazin et al.

Distributed under

Creative Commons CC-BY 4.0

OPEN ACCESS

\section{Protection of cultured brain endothelial cells from cytokine-induced damage by $\alpha$-melanocyte stimulating hormone}

\author{
András Harazin $^{1,2 * *}$, Alexandra Bocsik ${ }^{1, *}$, Lilla Barna ${ }^{1,2}$, András Kincses ${ }^{1}$, \\ Judit Váradi ${ }^{3}$, Ferenc Fenyvesi ${ }^{3}$, Vilmos Tubak ${ }^{4}$, Maria A. Deli ${ }^{1}$ and \\ Miklós Vecsernyés ${ }^{3}$ \\ ${ }^{1}$ Institute of Biophysics, Biological Research Centre, Hungarian Academy of Sciences, Szeged, \\ Hungary \\ ${ }^{2}$ Doctoral School in Biology, Faculty of Science and Informatics, University of Szeged, Szeged, \\ Hungary \\ ${ }^{3}$ Department of Pharmaceutical Technology, Faculty of Pharmacy, University of Debrecen, \\ Debrecen, Hungary \\ ${ }^{4}$ Creative Laboratory Ltd., Szeged, Hungary \\ * These authors contributed equally to this work.
}

\section{ABSTRACT}

The blood-brain barrier (BBB), an interface between the systemic circulation and the nervous system, can be a target of cytokines in inflammatory conditions. Pro-inflammatory cytokines tumor necrosis factor- $\alpha$ (TNF- $\alpha$ ) and interleukin- $1 \beta$ (IL-1 $\beta$ ) induce damage in brain endothelial cells and BBB dysfunction which contribute to neuronal injury. The neuroprotective effects of $\alpha$-melanocyte stimulating hormone $(\alpha-\mathrm{MSH})$ were investigated in experimental models, but there are no data related to the BBB. Based on our recent study, in which $\alpha-\mathrm{MSH}$ reduced barrier dysfunction in human intestinal epithelial cells induced by TNF- $\alpha$ and IL-1 $\beta$, we hypothesized a protective effect of $\alpha-\mathrm{MSH}$ on brain endothelial cells. We examined the effect of these two pro-inflammatory cytokines, and the neuropeptide $\alpha$-MSH on a culture model of the BBB, primary rat brain endothelial cells cocultured with rat brain pericytes and glial cells. We demonstrated the expression of melanocortin-1 receptor in isolated rat brain microvessels and cultured brain endothelial cells by RT-PCR and immunohistochemistry. TNF- $\alpha$ and IL-1 $\beta$ induced cell damage, measured by impedance and MTT assay, which was attenuated by $\alpha$-MSH ( 1 and $10 \mathrm{pM}$ ). The peptide inhibited the cytokine-induced increase in brain endothelial permeability, and restored the morphological changes in cellular junctions visualized by immunostaining for claudin- 5 and $\beta$-catenin. Elevated production of reactive oxygen species and the nuclear translocation of NF- $\mathrm{KB}$ were also reduced by $\alpha-\mathrm{MSH}$ in brain endothelial cells stimulated by cytokines. We demonstrated for the first time the direct beneficial effect of $\alpha$-MSH on cultured brain endothelial cells, indicating that this neurohormone may be protective at the BBB.

Subjects Cell Biology, Neuroscience, Pharmacology

Keywords Brain endothelial cells, Permeability, $\alpha$-Melanocyte-stimulating hormone, Cytokines, Tight junction, Blood-brain barrier, Melanocortin-1 receptor, Reactive oxygen species 


\section{INTRODUCTION}

The neuropeptide $\alpha$-melanocyte stimulating hormone ( $\alpha-\mathrm{MSH})$ belongs to the family of melanocortins, which are created from pro-opiomelanocortin (Catania et al., 2010). The $\alpha-\mathrm{MSH}$, a 13 amino acid long peptide hormone, is mainly produced in the hypothalamic region (Brzoska et al., 2008). Induction of melanogenesis in pigment cells and immunomodulation are among its main physiological functions (Catania, 2008). There are five melanocortin receptors (MCRs), from which four, MC1R, MC3R, MC4R, and MC5R, bind $\alpha-M S H$ (Brzoska et al., 2008). MCRs are G-protein-coupled and exert their effects via cyclic $3^{\prime}, 5^{\prime}$-adenosine monophosphate (cAMP)-dependent signaling pathways. The predominant receptor of $\alpha-\mathrm{MSH}$ is MC1R, which binds the neuropeptide with high affinity, and is expressed in both the brain and periphery. MC1R was demonstrated in several tissues, such as brain, skin, immune system, and gut (Brzoska et al., 2008).

Melanocortins are evolutionary conserved defense molecules against tissue injury and bacterial invasion (Catania, 2008). The immunomodulatory and anti-inflammatory effects of $\alpha-\mathrm{MSH}$ are well known and widely investigated. The anti-inflammatory action of $\alpha$-MSH was proven in animal models of systemic or local inflammation, like sepsis, arthritis, uveitis, dermatitis, pancreatitis, and colitis (Brzoska et al., 2008). The protective effect of $\alpha$-MSH was also shown in ischemic conditions in the heart (Vecsernyés et al., 2003, 2017), retina (Varga et al., 2013), kidney and intestine (Brzoska et al., 2008). In addition to animal models of gut inflammation (Rajora et al., 1997a), the effects of $\alpha-\mathrm{MSH}$ were examined on cell cultures. Our groups have recently described that pro-inflammatory cytokines tumor necrosis factor- $\alpha$ (TNF- $\alpha$ ) and interleukin- $1 \beta$ (IL-1 $\beta$ ) disrupted the barrier integrity of Caco-2 human intestinal epithelial cells, which was attenuated by $\alpha-\mathrm{MSH}$ via the inhibition of the NF-KB pathway (Váradi et al., 2017).

In addition to systemic inflammatory conditions, the beneficial effect of $\alpha-\mathrm{MSH}$ was also investigated in models of acute and chronic injuries of the central nervous system (CNS; Catania, 2008). Treatment with $\alpha$-MSH was neuroprotective in cerebral ischemia, traumatic spinal cord injury, kainic acid induced excitotoxic brain damage, and lipopolysaccharide (LPS)-induced cerebral inflammation in animal studies. One of the main mechanisms of action of $\alpha-\mathrm{MSH}$ is the down-regulation of pro-inflammatory cytokines TNF- $\alpha$ and/or IL- $1 \beta$ in blood and brain tissue, as it was described in LPS-induced brain inflammation (Rajora et al., 1997b) and unilateral middle cerebral artery occlusion (Huang \& Tatro, 2002) in mice, and in kainic acid-induced brain damage in rats (Forslin Aronsson et al., 2007). Studies on cultured astrocytes, neurons, and microglia revealed that, similarly to the periphery, inhibition of the NF- $\mathrm{KB}$ pathway and downstream blockade of pro-inflammatory cytokine release and nitric oxide overproduction contribute to the protective effects of $\alpha-\mathrm{MSH}$ (Catania, 2008).

Dysfunction of the blood-brain barrier (BBB) has been described in many systemic and CNS inflammatory diseases (Erickson \& Banks, 2018) and plays a central role in the pathomechanism of many neurological diseases (Zhao et al., 2015; Liebner et al., 2018). TNF- $\alpha$ and IL-1 $\beta$ are the two most studied major pro-inflammatory cytokines in 
neuroinflammation observed in CNS pathologies (Sochocka, Diniz \& Leszek, 2017; Liebner et al., 2018), and induced by systemic inflammation (Hoogland et al., 2015). The elevated levels of these two cytokines, confirmed in chronic neurodegenerative diseases (Sochocka, Diniz \& Leszek, 2017), open the BBB (Liebner et al., 2018). TNF- $\alpha$ directly increases the permeability of the BBB for marker molecules in animal studies (Megyeri et al., 1992; Ábrahám et al., 1996), as well as in culture models (Deli et al., 1995) and a similar effect was described for IL- $1 \beta$ in BBB in vitro experiments (for review see Deli et al., 2005). Since these two pro-inflammatory cytokines are major players in both systemic and CNS inflammation and induce BBB dysfunction, TNF- $\alpha$ and IL- $1 \beta$ were selected for our experiments.

A binding site was found on murine brain endothelial cells by radiolabeled $\alpha-\mathrm{MSH}$ (de Angelis et al., 1995), suggesting the presence of MCR(s) at the BBB, but they were not identified. MCRs expressed on cells of the neurovascular unit could mediate the neuroprotective actions of melanocortins (Catania, 2008), however, the effects of $\alpha-\mathrm{MSH}$ on the BBB, especially on brain endothelial cells have not been investigated yet.

Therefore, our aim was to investigate the effects of $\alpha$-MSH peptide on a culture model of the $\mathrm{BBB}$, its possible protective action against barrier disruption induced by TNF- $\alpha$ and IL-1 $\beta$ cytokines by measuring cellular viability, permeability for marker molecules, structure of interendothelial tight junctions, production of reactive oxygen species (ROS) and the nuclear translocation of NF- $\kappa B$ p 65 subunit.

\section{MATERIALS AND METHODS}

\section{Materials}

All reagents were purchased from Sigma-Aldrich Corporation (subsidiary of Merck KGaA, Darmstadt, Germany) unless otherwise indicated.

\section{Cell culture}

Primary rat brain endothelial cells were isolated from three week-old outbred Wistar rats (Harlan Laboratories, Indianapolis, IN, USA) as described in our previous paper (Veszelka et al., 2013). Forebrains were collected in ice-cold sterile phosphate buffered saline (PBS). After meninges were removed the tissue was cut into $1 \mathrm{~mm}^{3}$ pieces by scalpel and digested with enzymes $(1 \mathrm{mg} / \mathrm{ml}$ collagenase type II, and $15 \mu \mathrm{g} / \mathrm{ml}$ deoxyribonuclease type I; Roche, Basel, Switzerland) in Dulbecco's modified Eagle medium (DMEM/F12, Gibco; Life Technologies, Carlsbad, CA, USA) at $37^{\circ} \mathrm{C}$ for $55 \mathrm{~min}$. Microvessels were separated from myelin rich fraction by centrifugation in 20\% BSA-DMEM gradient $(1,000 \times g, 20 \mathrm{~min}$, three times). The collected vessels were further digested with enzymes ( $1 \mathrm{mg} / \mathrm{ml}$ collagenase-dispase, and $15 \mu \mathrm{g} / \mathrm{ml}$ deoxyribonuclease type I; Roche, Basel, Switzerland) in DMEM/F12 at $37^{\circ} \mathrm{C}$ for $35 \mathrm{~min}$. Brain microvascular endothelial cell clusters were separated on a $33 \%$ continuous Percoll gradient $(1,000 \times \mathrm{g}, 10 \mathrm{~min})$, collected, and washed twice in DMEM/F12. Cells were seeded onto Petri dishes (100 mm; Orange Scientific, Braine-l'Alleud, Belgium) coated with collagen type IV and fibronectin $(100 \mu \mathrm{g} / \mathrm{ml}$ each). Cultures were maintained in DMEM/F12 
supplemented with 15\% plasma-derived bovine serum (First Link, Wolverhampton, UK), $5 \mu \mathrm{g} / \mathrm{ml}$ insulin-transferrin-sodium selenite (Pan Biotech, Aidenbach, Germany), $1 \mathrm{ng} / \mathrm{ml}$ basic fibroblast growth factor (Roche, Basel, Switzerland), $100 \mu \mathrm{g} / \mathrm{ml}$ heparin, and $5 \mu \mathrm{g} / \mathrm{ml}$ gentamycin. For the first three days of culture cells were grown in medium with $3 \mu \mathrm{g} / \mathrm{ml}$ puromycin to eliminate P-glycoprotein negative contaminating cell types (Perrière et al., 2005). When endothelial cells reached 90\% confluency, they were subcultivated for different experiments.

Primary rat brain pericytes were isolated by the same method, except that the second digestion lasted only for $15 \mathrm{~min}$. After isolation cells were plated onto uncoated dishes and they were cultured in low-glucose DMEM medium (Gibco, Life Technologies, Carlsbad, CA, USA) supplemented with 10\% FBS (Pan Biotech, Aidenbach, Germany) and gentamycin. No puromycin was applied. Pericytes were used at third passage for experiments.

Primary rat glial cells were isolated from one-day-old Wistar rats. After meninges were removed brain tissue was mechanically dissociated by a syringe equipped with a long needle. The tissue homogenate was filtered through a nylon mesh ( $40 \mu \mathrm{m}$; Millipore, Billerica, MA, USA) to remove large tissue pieces and vessels. Cell clusters in the filtrate were plated onto uncoated $75 \mathrm{~cm}^{2}$ flasks (TPP, Trasadingen, Switzerland), cultured until $90 \%$ confluency in DMEM containing 10\% FBS (Lonza, Basel, Switzerland) and gentamycin. For the BBB co-culture model glial cells were passaged at a cell number of $5 \times$ $10^{4}$ cells/well for 12-well plates (Corning Costar, Corning, NY, USA) and cultured for two weeks before use. Confluent glia cultures contained 90\% of GFAP immunopositive astroglia, and $10 \% \mathrm{CD} 11 \mathrm{~b}$ immunopositive microglia.

To induce BBB characteristics brain endothelial cells were co-cultured with brain pericytes and glial cells (Nakagawa et al., 2009) using 12-well format tissue culture inserts (Transwell clear, polyester membrane, $0.4 \mu \mathrm{m}$ pore size, $1.12 \mathrm{~cm}^{2}$ surface; Corning Costar, Corning, NY, USA). Rat pericytes $\left(1.5 \times 10^{4} \mathrm{cells} / \mathrm{cm}^{2}\right)$ were subcultivated to the bottom side of the insert membranes and brain endothelial cells $\left(7.5 \times 10^{4} \mathrm{cells} / \mathrm{cm}^{2}\right)$ were passaged to the upper side of the collagen type IV and fibronectin coated inserts. Both compartments received endothelial culture medium. After two days of co-culture, brain endothelial cells reached confluency and $550 \mathrm{nM}$ hydrocortisone was added to the culture medium to tighten junctions (Walter et al., 2015). Before experiments $250 \mu \mathrm{M}$ 8-(4-chlorophenylthio)-cAMP and 17.5 $\mu \mathrm{M}$ Ro 20-1724 (Roche, Basel, Switzerland) were added to the endothelial cells for $24 \mathrm{~h}$ to tighten junctions and elevate resistance (Deli et al., 2005; Perrière et al., 2005).

\section{Treatments}

The neuropeptide $\alpha-\mathrm{MSH}$ (Mw. $1664.8 \mathrm{Da}$ ) was tested at $1 \mathrm{pM}$ to $1 \mu \mathrm{M}$ concentrations. The use of cytokine cocktails is common in CNS culture studies (Sochocka, Diniz \& Leszek, 2017). We have also used a combination of TNF- $\alpha(50 \mathrm{ng} / \mathrm{ml})$ and IL- $1 \beta(25 \mathrm{ng} / \mathrm{ml})$ on intestinal epithelial cells in our previous study (Váradi et al., 2017). Based on this study, we have tested a combination of the pro-inflammatory cytokines TNF- $\alpha(10-50 \mathrm{ng} / \mathrm{ml})$ 
and IL-1 $\beta(10-25 \mathrm{ng} / \mathrm{ml})$ for $24 \mathrm{~h}$ to induce damage in brain endothelial cells. The control group received culture medium only.

\section{Total RNA isolation and RT-PCR}

Brain microvessels were isolated from adult rat brains as published earlier (Veszelka et al., 2007). For receptor expression analysis total RNA was isolated from isolated brain microvessels and brain endothelial cells by TRI Reagent (Molecular Research Center, Cincinnati, OH, USA). One microgram of total RNA was transcribed to cDNA by Maxima First Strand cDNA Synthesis Kit (ThermoFisher, Waltham, MA, USA). Specific oligonucleotide primers were designed for the Mc1r gene (XM_006222790). Primer sets were MC1R_fwd 5'-TGCACCTCTTGCTCATCGTT-3' and MC1R_rvs 5'-

ACCTCCTTGAGTGTCATGCG-3'. The predicted length of PCR product was $160 \mathrm{bps}$. Primers for $\beta$-actin were used as internal controls (NM_031144). Primer sets were ACT_fwd 5'-TACTCTGTGTGGATTGGTGGC-3' and ACT_rvs 5'-GGTGTAAAACGCAG CTCAGTAA- $3^{\prime}$. The predicted length of PCR product was 150 bps. PCR was performed with FIREPol DNA polymerase (Solis BioDyne, Tartu, Estonia) in T100 thermal cycler (BioRad, Hercules, CA, USA). After initial heat inactivation $\left(95^{\circ} \mathrm{C}\right.$ for $\left.3 \mathrm{~min}\right)$ the following cycling conditions were applied: melting $94^{\circ} \mathrm{C}$ for $15 \mathrm{~s}$, annealing $50{ }^{\circ} \mathrm{C}$ for $15 \mathrm{~s}$, polimerization $72{ }^{\circ} \mathrm{C}$ for $20 \mathrm{~s}$ ( 35 cycles). After a final 5 min extension at $72{ }^{\circ} \mathrm{C} \mathrm{PCR}$ products were analyzed on 3\% MetaPhor agarose gel (Cambrex BioScience, Rockland, ME, USA) and fragments were verified by capillary DNA sequencing.

\section{Measurement of cell viability: real-time cell electronic sensing and MTT assay}

Real-time cell electronic sensing is an impedance-based, label-free technique for dynamic monitoring of living adherent cells, including barrier forming epithelial and brain endothelial cells (Kiss et al., 2014; Lénárt et al., 2015). The RTCA-SP instrument (ACEA Biosciences, San Diego, CA, USA) registers the impedance of cells in every $10 \mathrm{~min}$ and for each time point cell index is calculated as $(\mathrm{Rn}-\mathrm{Rb}) / 15$, where $\mathrm{Rn}$ is the cell-electrode impedance of the well when it contains cells and $\mathrm{Rb}$ is the background impedance of the well with the medium alone. E-plates, special 96-well plates with built in gold electrodes, were coated with collagen type IV and fibronectin for brain endothelial cells at room temperature and dried for 20 min under UV and air-flow. For background measurements culture medium $(60 \mu \mathrm{l})$ was added to each well, then $50 \mu \mathrm{l}$ of rat brain endothelial cell suspension was distributed at a cell density of $5 \times 10^{3}$ cells/well. After cells reached a steady growth phase they were treated with $\alpha-\mathrm{MSH}$ and cytokines.

In parallel we also used an endpoint colorimetric cell viability assay (Kiss et al., 2014). The yellow 3-(4,5-dimethylthiazol-2-yl)-2,5-diphenyltetrazolium bromide (MTT) dye is converted by viable cells to purple formazan crystals. Brain endothelial cells were grown in 96-well plates coated with collagen type IV and fibronectin. After treatment of confluent monolayers, cells were incubated with $0.5 \mathrm{mg} / \mathrm{ml}$ MTT solution in cell culture medium for $3 \mathrm{~h}$ in $\mathrm{CO}_{2}$ incubator. Formazan crystals were dissolved in dimethyl 
sulfoxide, and dye concentration was determined by absorbance measurement at $570 \mathrm{~nm}$ with a multiwell plate reader (Fluostar Optima; BMG Labtechnologies, Offenburg, Germany).

\section{Measurement of permeability for marker molecules}

Penetration of fluorescein isothiocyanate-labeled dextran (FITC-dextran, MW: $4.4 \mathrm{kDa}$ ) and Evans blue-labeled albumin (EBA, MW: $67 \mathrm{kDa}$ ) across the BBB model was determined in permeability studies (Veszelka et al., 2007). Rat brain endothelial cells co-cultured with pericytes and glia on cell culture inserts were treated with cytokines and/or $\alpha$-MSH for $1 \mathrm{~h}$. After treatment inserts were transferred to 12 -well plates containing $1.5 \mathrm{ml}$ Ringer-HEPES buffer $\left(150 \mathrm{mM} \mathrm{NaCl}, 2.2 \mathrm{mM} \mathrm{CaCl}, 0.2 \mathrm{mM} \mathrm{MgCl}_{2}\right.$, $5.2 \mathrm{mM} \mathrm{KCl}, 6 \mathrm{mM} \mathrm{NaHCO} 3,5 \mathrm{mM}$ glucose, and $10 \mathrm{mM}$ HEPES, pH 7.4) in the lower compartments. In the upper compartments culture medium was replaced by $500 \mu \mathrm{l}$ Ringer-HEPES buffer containing EBA complex $(1 \mathrm{mg} / \mathrm{ml}$ bovine serum albumin and $167.5 \mu \mathrm{g} / \mathrm{ml}$ Evans blue) and FITC-dextran $(100 \mu \mathrm{g} / \mathrm{ml})$. The plates were kept for $30 \mathrm{~min}$ on a rocking platform $(100 \mathrm{rpm})$ at $37{ }^{\circ} \mathrm{C}$ in an incubator with $5 \% \mathrm{CO}_{2}$. After the incubation the concentrations of the marker molecules in samples from the upper and lower compartments were determined by a fluorescence multiwell plate reader (Fluostar Optima; BMG Labtechnologies, Offenburg, Germany; excitation wavelength: $485 \mathrm{~nm}$, emission wavelength: $520 \mathrm{~nm}$ for FITC-dextran; excitation wavelength: $584 \mathrm{~nm}$, emission wavelength: $680 \mathrm{~nm}$ for EBA). The apparent permeability coefficients $\left(P_{\text {app }}\right)$ were calculated by the following equation (Váradi et al., 2017):

$P_{\text {app }}=\frac{[C]_{B} \times V_{B}}{A \times[C]_{A} \times t}$

where $[C]_{B}$ is the concentration of the tracer in the lower (basal) compartment after $1 \mathrm{~h}$, $[C]_{A}$ is the concentration of the tracer in the upper (apical) compartment at $0 \mathrm{~h}, V_{B}$ is the volume of the basal compartment $(1.5 \mathrm{ml})$ and $A$ is the surface area available for permeability $\left(1.12 \mathrm{~cm}^{2}\right)$.

\section{Immunohistochemistry} Melanocortin-1 receptor

Isolated rat brain microvessels and brain endothelial cells, co-cultured with brain pericytes and glial cells, were immunostained for MC1R as we described in our previous paper for epithelial cells (Váradi et al., 2017). Cells were washed in PBS, fixed with ice cold acetone/methanol solution (1:1) for $5 \mathrm{~min}$, and blocked with 3\% BSA-PBS for $1 \mathrm{~h}$. A rabbit anti-human MC1R antibody (M9193; $1 \mathrm{mg} / \mathrm{ml}$ ) was used as primary antibody for overnight at $4{ }^{\circ} \mathrm{C}$. Incubation with secondary antibody, Alexa Fluor 488 conjugated goat-anti-rabbit IgG (A11029; ThermoFisher Scientific, Waltham, MA, USA; $2 \mathrm{mg} / \mathrm{ml}$ ) and nucleus stain ethidium homodimer-1 $(1 \mu \mathrm{M})$ lasted for $1 \mathrm{~h}$. The samples were thoroughly washed with PBS after each step and mounted in Fluoromount-G (Southern Biotech, Birmingham, AL, USA). Stainings were visualized by a Leica SP5 confocal laser scanning microscope (Leica Microsystems GmbH, Wetzlar, Germany). 


\section{Junctional proteins and NF-KB p65 subunit}

Rat brain endothelial cells treated with cytokines and/or $\alpha-\mathrm{MSH}$ for $1 \mathrm{~h}$ were fixed and permeabilized with ice cold acetone/methanol solution (1:1) and blocked in 3\% BSA-PBS for $1 \mathrm{~h}$. Cell were incubated with rabbit anti-rat $\beta$-catenin polyclonal (C2206; $1 \mathrm{mg} / \mathrm{ml}$ ) or rabbit anti-rat claudin-5 polyclonal (SAB4502981; $1 \mathrm{mg} / \mathrm{ml}$ ) primary antibodies overnight, followed by secondary labeling with Cy3-conjugated goat-anti-rabbit IgG $(\mathrm{C} 2306 ; 2 \mathrm{mg} / \mathrm{ml})$ and a nucleus stain $(\mathrm{H} 33342 ; 1 \mu \mathrm{g} / \mathrm{ml})$ for $1 \mathrm{~h}$. For NF- $\mathrm{KB}$ p65 subunit immunostaining a rabbit anti-human p65 polyclonal antibody (sc-372; Santa Cruz Biotechnology, Dallas, TX, USA; $100 \mu \mathrm{g} / \mathrm{ml}$, overnight incubation) was used, followed by incubation with Alexa Fluor 488-conjugated goat-anti-rabbit IgG (A11029; ThermoFisher Scientific, Waltham, MA, USA; $2 \mathrm{mg} / \mathrm{ml}$ ) and $\mathrm{H} 33342$ for $1 \mathrm{~h}$. Cells were washed and mounted as described above. For both TJ protein and NF- $\mathrm{KB}$ stainings samples were observed by a Leica SP5 confocal laser scanning microscope. Images showing TJ staining were analyzed using MATLAB software (MathWorks, Natick, MA, USA). The backgrounds of each image were determined and subtracted from the corresponding image to compensate the occasional non-uniform background. Then, the grayscale images were converted to binary. Objects with size less than 6 pixels were eliminated to reduce any false structure. The areas of the structures were determined by the pixel number of the structures on the binary images. The object number defines the number of the separated, non-contact structure elements of the images. Images of NF- $\kappa B$ immunostaining were analyzed using ImageJ software (National Institutes of Health, Rockville, MD, USA) as described in our previous paper (Sántha et al., 2016).

\section{Measurement of ROS production}

Reactive oxygen species production was detected by chloromethyl-dichloro-dihydrofluorecein diacetate (DCFDA; Life Technologies, Carlsbad, CA, USA) as we described previously (Veszelka et al., 2013; Lénárt et al., 2015). The indicator penetrates into the cells and interacts with intracellular esterases. After its oxidation fluorescent molecules are produced, and the fluorescent signal is proportional to the produced ROS. Confluent brain endothelial cells were cultured in black 96-well plates with glass bottoms (Corning Costar, Corning, NY, USA). After $1 \mathrm{~h}$ treatment cells were incubated with Ringer-HEPES buffer containing $2 \mu \mathrm{M}$ DCFDA for $1 \mathrm{~h}$ at $37^{\circ} \mathrm{C}$. Hydrogen peroxide $(100 \mu \mathrm{M})$ was used as a reference compound (positive control). Fluorescence was measured at $485 \mathrm{~nm}$ excitation and $520 \mathrm{~nm}$ emission wavelengths by a Fluostar Optima multiwell plate reader (BMG Labtechnologies, Offenburg, Germany) every $5 \mathrm{~min}$ for $1 \mathrm{~h}$. Fluorescence intensities are shown in arbitrary units.

\section{Statistical analysis}

Statistical analysis was done by GraphPad Prism 5.0 software (GraphPad Software Inc., La Jolla, CA, USA). Data are presented as mean \pm SEM. Comparison of groups was performed using ANOVA and Dunnett or Bonferroni tests. Differences were considered significant at $P<0.05$. 


\section{RESULTS}

\section{Expression of melanocortin-1 receptor on rat brain microvessels and cultured brain endothelial cells}

MC1R gene expression was detected on both freshly isolated rat brain microvessels and confluent rat brain endothelial cell cultures with reverse transcription followed by PCR amplification using the specifically designed rat primers (Fig. 1A). This result was strengthened by immunohistochemistry for MC1R. The brain endothelial staining (Fig. 1B) was similar to the apical surface staining of MC1R on Caco-2 cells in our previous work (Váradi et al., 2017). Positive MC1R immunostaining was found on freshly isolated brain microvessels, too (Fig. 1C).

\section{Effect of $\alpha-M S H$ on rat brain endothelial cell metabolism and viability}

Treatment of rat brain endothelial cells with $\alpha$-MSH peptide alone ( 1 pM to $1 \mu \mathrm{M})$ did not have any significant effect on cell kinetics measured by impedance, indicating good cell viability, attachment and barrier integrity. Followed by real-time cell electronic sensing the cells showed no change after $\alpha$-MSH treatment, the kinetic curves ran similarly to the untreated control samples (Fig. 2A). In addition, the colorimetric MTT assay also did not detect any metabolic change in cells after $24 \mathrm{~h}$ treatment with $\alpha-\mathrm{MSH}$ as compared to control (Fig. 2B). For further experiments 1 and $10 \mathrm{pM}$ concentrations of $\alpha-\mathrm{MSH}$ were selected, which correspond to the physiological range of the neurohormone in the blood (Kovács et al., 2001; Magnoni et al., 2003).

\section{Effect of $\alpha-\mathrm{MSH}$ on cytokine treated rat brain endothelial barrier integrity: real-time cell kinetics}

To determine the treatment concentrations of TNF- $\alpha$ and IL- $1 \beta$ to induce brain endothelial damage, four different combinations of cytokine concentrations $(10+10,10+25,25+25,50+25 \mathrm{ng} / \mathrm{ml})$ were tested (Fig. 3A). The cytokine combination in the tested concentration range decreased brain endothelial viability. There were no statistically significant differences between the four cytokine treatment groups. For further experiments the smallest, $10+10 \mathrm{ng} / \mathrm{ml}$ concentrations of the cytokines were selected. Treatment of rat brain endothelial cells with TNF- $\alpha$ and IL-1 $\beta$ decreased the cell index by more than $50 \%$ at $6 \mathrm{~h}$ time point which further dropped by $24 \mathrm{~h}$ (Fig. 3B). Low concentration of $\alpha-\mathrm{MSH}$ ( $1 \mathrm{pM}$ ) significantly protected against the cytokine-induced cell viability decrease (Fig. 3C). There was no statistically significant difference between the two cytokine $+\alpha-\mathrm{MSH}$ treatment groups.

\section{Effect of $\alpha-\mathrm{MSH}$ on cytokine treated rat brain endothelial barrier integrity: permeability for marker molecules}

The integrity of brain endothelial monolayers was tested by its permeability for marker molecules. A low permeability for both FITC-dextran $\left(1.91 \pm 0.02 \times 10^{-6} \mathrm{~cm} / \mathrm{s}\right)$ and large biomolecule albumin $\left(0.88 \pm 0.13 \times 10^{-6} \mathrm{~cm} / \mathrm{s}\right)$ was measured on the triple co-culture model of the BBB. Cytokine treatment significantly increased the permeability of the co-cultures 
A

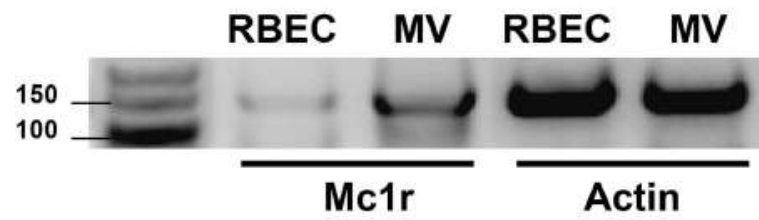

B

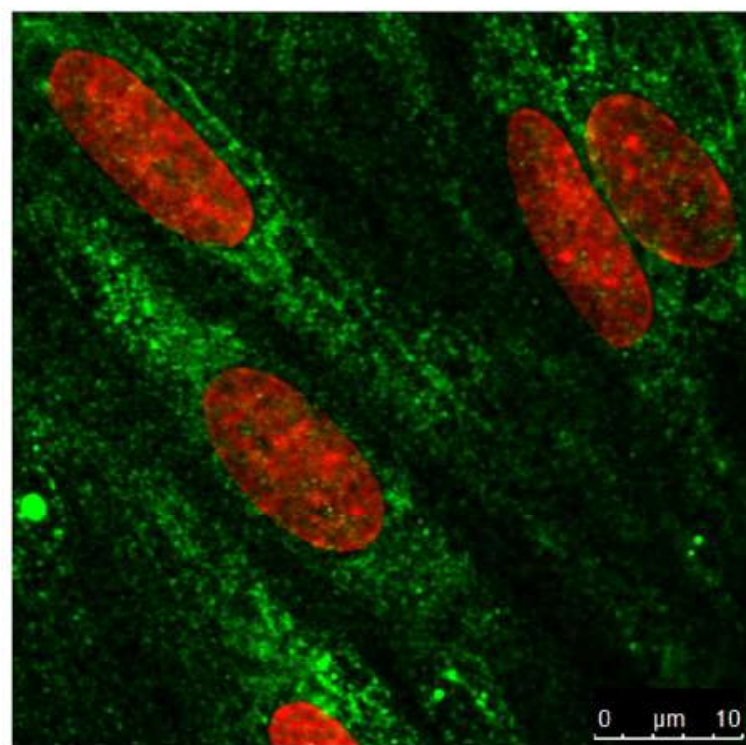

C

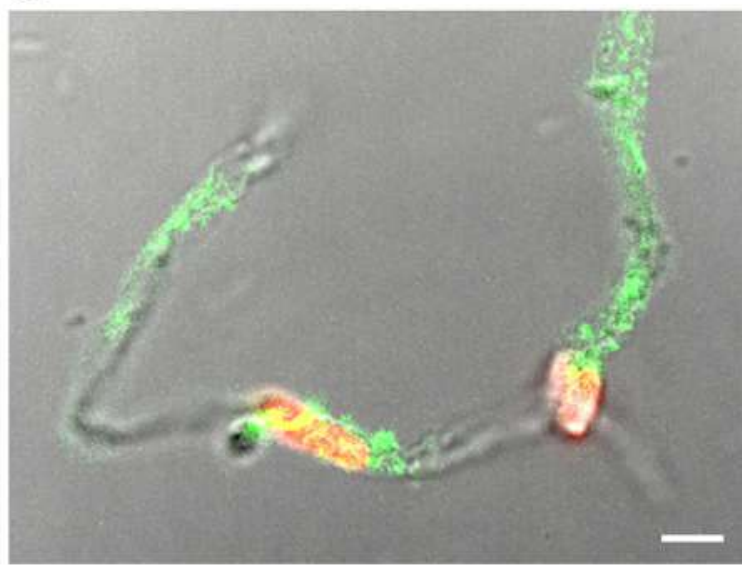

Figure 1 Melanocortin-1 receptor (MC1R) expression on rat brain endothelial cells and isolated rat brain microvessels. (A) Cells were grown in culture dish and brain microvessels were isolated from adult rat brain. Total RNA was extracted, and reverse transcription and PCR amplification were performed for Mc1r. Actin gene was used as reference. The predicted length of the PCR products was $160 \mathrm{bps}$. Fragments were analyzed on MetaPhor agarose gel (3\%) next low range DNA marker. (B) Cultured brain endothelial cells were grown on culture inserts and immunostained for MC1R. Cell nuclei were labeled with ethidium homodimer-1 (red). Green: MC1R labeling. Scale bar: $10 \mu \mathrm{m}$. (C) Isolated brain microvessels were immunostained for MC1R. Fluorescent labeling is shown together with differential interference contrast to reveal the structure of brain capillary. Cell nuclei were labeled with ethidium homodimer-1 (red). Green: MC1R labeling. Scale bar: $5 \mu \mathrm{m}$. MC1R, melanocortin-1 receptor; RBEC, rat brain endothelial cells; MV, microvessels. Full-size [D DOI: 10.7717/peerj.4774/fig-1 
A

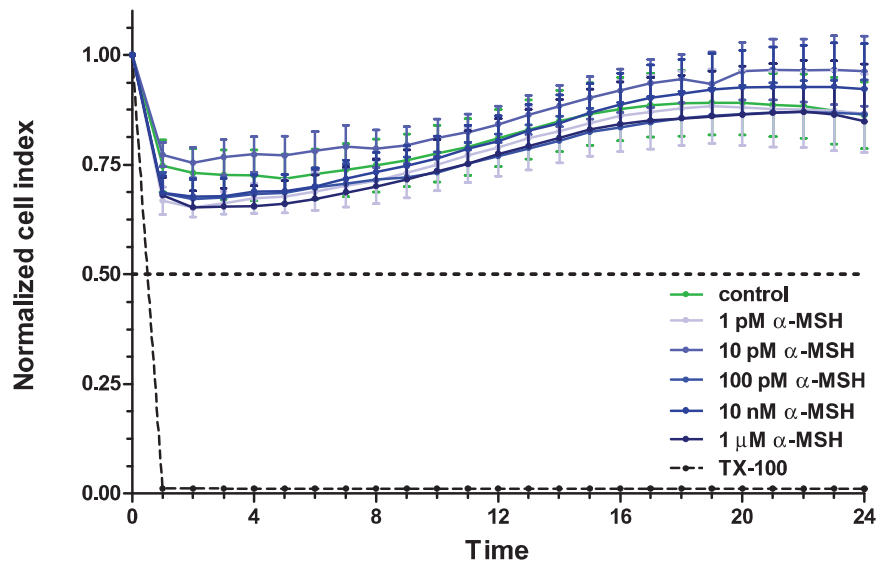

B

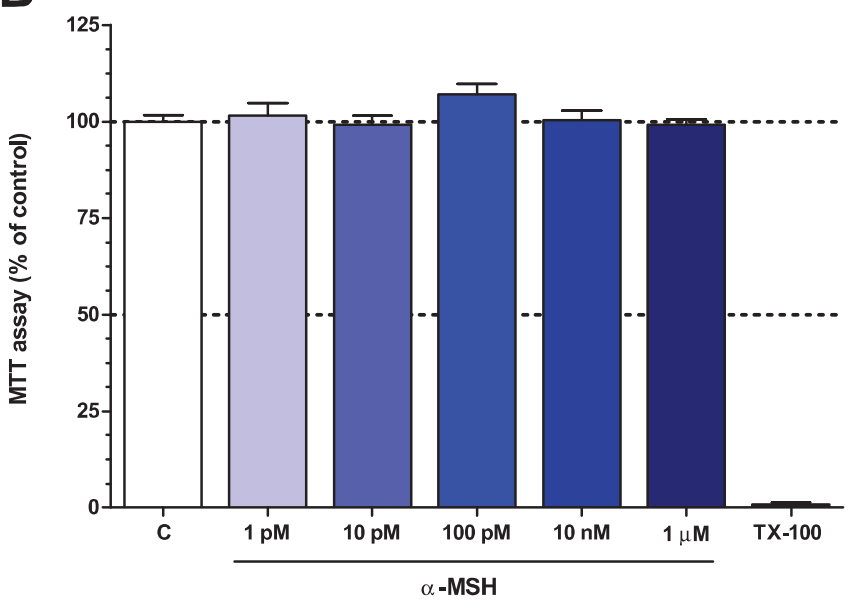

Figure 2 The effect of different concentrations of $\alpha-\mathrm{MSH}$ on the cell viability of rat brain endothelial cells. (A) Cultured brain endothelial cells were treated with $\alpha$-MSH ( $1 \mathrm{pM}$ to $1 \mu \mathrm{M}$ ) for $24 \mathrm{~h}$. Control group received culture medium. Endothelial cells treated with $1 \%$ Triton X-100 detergent were used as cytotoxicity control. The cell index followed by impedance did not change after $\alpha$-MSH treatment. (B) The metabolic activity of rat brain endothelial cells was measured by MTT assay, which did not detect any alteration caused by $\alpha-\mathrm{MSH}$. Mean \pm SEM, $n=4-8$. C, control group; TX-100, Triton X-100. Full-size

for both markers (Fig. 4). The lower, $1 \mathrm{pM}$ concentration of $\alpha$-MSH peptide significantly blocked the barrier opening effect of the cytokines for FITC-dextran and albumin, while 10 pM $\alpha$-MSH significantly strengthened the cellular barrier for the bigger marker molecule.

\section{Effect of $\alpha-\mathrm{MSH}$ on cytokine treated rat brain endothelial barrier integrity: immunostaining for claudin-5 and $\beta$-catenin junctional proteins}

Rat brain endothelial cells form tight paracellular barrier, which was visualized by the localization of integral membrane TJ protein claudin- 5 and adherens junction protein $\beta$-catenin (Fig. 5). These junctional proteins appeared in the cell membranes in a continuous, belt-like manner. In the control, untreated group continuous stainings were visible without gaps at the cell border. In the cytokine treated group gaps and fragmented junctional staining (arrowheads, Fig. 5A) and cytoplasmic redistribution of junctional proteins (asterisks, Fig. 5A) were observed. In cells treated with both $\alpha-\mathrm{MSH}$ and cytokine the staining of TJ proteins was more similar to the control group. The object number on the immunostained pictures significantly increased due to cytokine treatment as compared to the control and $\alpha-\mathrm{MSH}$ treated group (Figs. 5B and 5C).

\section{Effect of $\alpha-M S H$ on cytokine treated rat brain endothelial cells: ROS production}

Treatment with TNF- $\alpha$ and IL- $1 \beta$ significantly increased ROS production in brain endothelial cells compared to the basal ROS production of the control group (Fig. 6). Low concentrations of $\alpha-\mathrm{MSH}$ peptide alone did not change the basal ROS production, while it could statistically significantly decrease the cytokine-induced ROS production in cultured brain endothelial cells. Hydrogen peroxide treatment was used as a reference inducer of ROS in the assay, as in our previous study (Veszelka et al., 2013). 
A

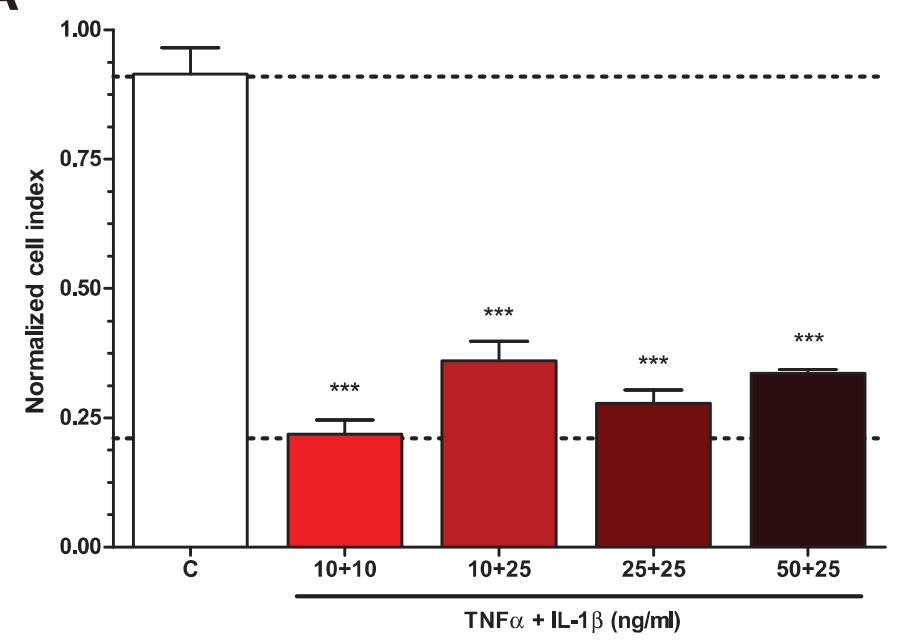

B

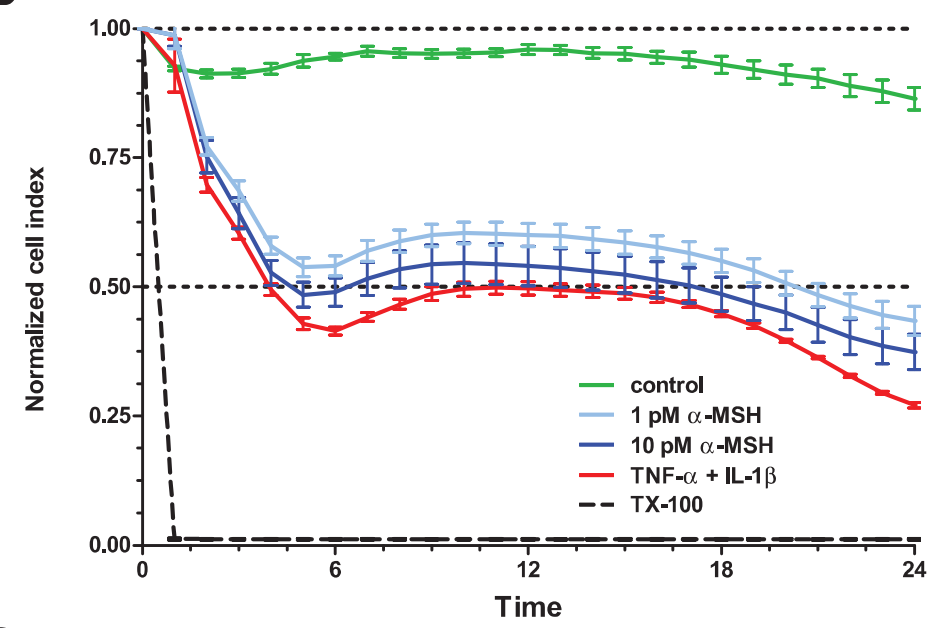

C

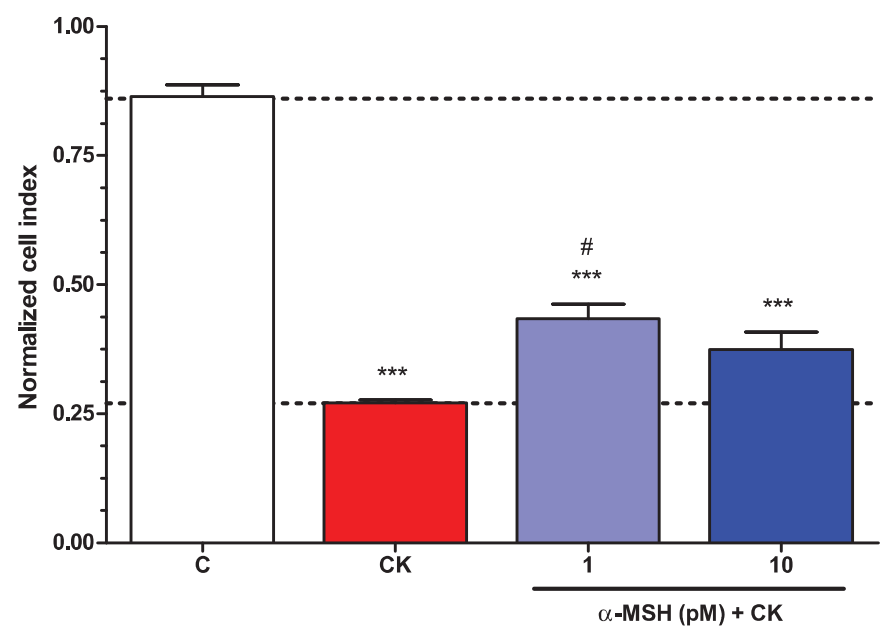


Figure 3 The effect of $\alpha$-MSH treatment on cell viability of cytokine treated rat brain endothelia cells. (A) Rat brain endothelial cells were treated with four different combinations of cytokine concentrations (TNF- $\alpha+$ IL- $1 \beta: 10+10,10+25,25+25$, and $50+25 \mathrm{ng} / \mathrm{ml}$ ) for $24 \mathrm{~h}$ and the cellular effects were monitored by impedance. Control group received culture medium. (B) Rat brain endothelial cells were treated with cytokines ( $10 \mathrm{ng} / \mathrm{ml} \mathrm{TNF}-\alpha$ and $10 \mathrm{ng} / \mathrm{ml} \mathrm{IL}-1 \beta$ ) without or with $\alpha-\mathrm{MSH}$ ( 1 and $10 \mathrm{pM})$ and the cellular effects were monitored by impedance for $24 \mathrm{~h}$. Control group received culture medium. The cytokines decreased the cell index, which effect could be ameliorated by $\alpha$-MSH treatment, especially by the lower, $1 \mathrm{pM} \alpha-\mathrm{MSH}$ concentration. (C) After $24 \mathrm{~h}$ treatment the cell viability significantly decreased due to cytokine treatment, while $1 \mathrm{pM} \alpha$-MSH significantly blocked the cytokine effect. Mean \pm SEM, $n=3-6,{ }^{* * *} P<0.001,{ }^{\#} P<0.05$. Asterisks indicate that groups were compared to the control group. Pound signs indicate that groups were compared to the cytokine-treated group. C, control group; CK, cytokine treated group.

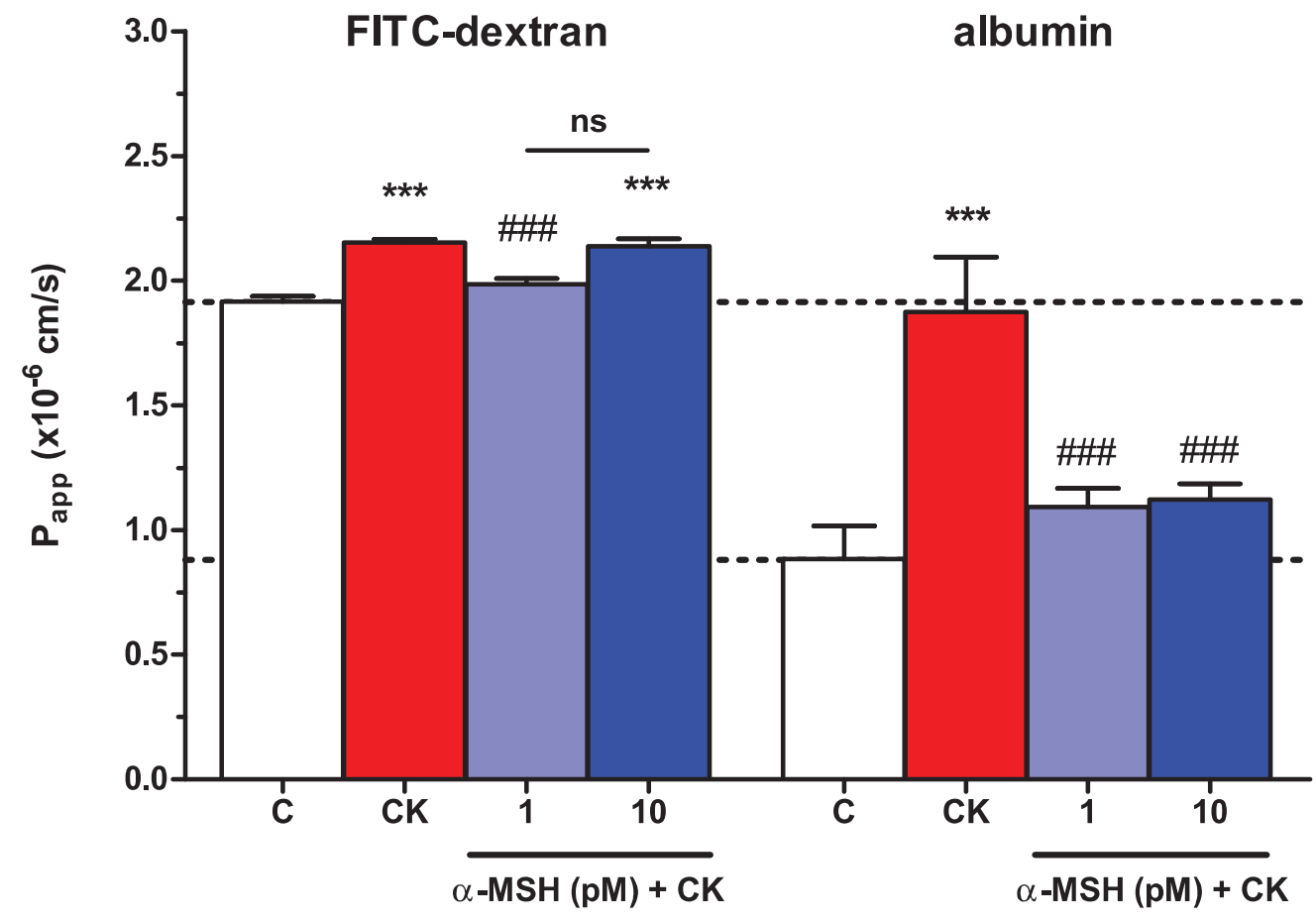

Figure 4 The effect of $\alpha$-MSH treatment on the permeability of cytokine treated triple co-culture model of the BBB. Brain endothelial cells co-cultured with pericytes and astrocytes on culture inserts were treated with cytokines ( $10 \mathrm{ng} / \mathrm{ml} \mathrm{TNF}-\alpha$ and $10 \mathrm{ng} / \mathrm{ml} \mathrm{IL-1} \beta$ ) without or with $\alpha-\mathrm{MSH}$ ( 1 or $10 \mathrm{pM}$ ) for $1 \mathrm{~h}$. Then, permeability was measured for $4 \mathrm{kDa}$ FITC-dextran and albumin. Control group received culture medium. Mean \pm SEM, $n=7-17,{ }^{* * *} P<0.001$. Asterisks indicate that groups were compared to the control group. Pound signs indicate that groups were compared to the cytokine-treated group. C, control group; CK, cytokine treated group; ns, no significant difference between the two groups. Full-size $\boldsymbol{\oplus}$ DOI: $10.7717 /$ peerj.4774/fig-4

\section{Effect of $\alpha-M S H$ on cytokine-induced NF-kB nuclear translocation in rat brain endothelial cells}

Cytokine treatment induced inflammatory reaction can be measured reliably by the translocation of the p65 subunit of NF- $\kappa B$ transcriptional factor into cell nuclei. In the control group the localization of NF- $\mathrm{KB}$ p65 is mostly cytoplasmic (Fig. 7A). Treatment with inflammatory cytokines induced the nuclear translocation of the transcription factor 
A
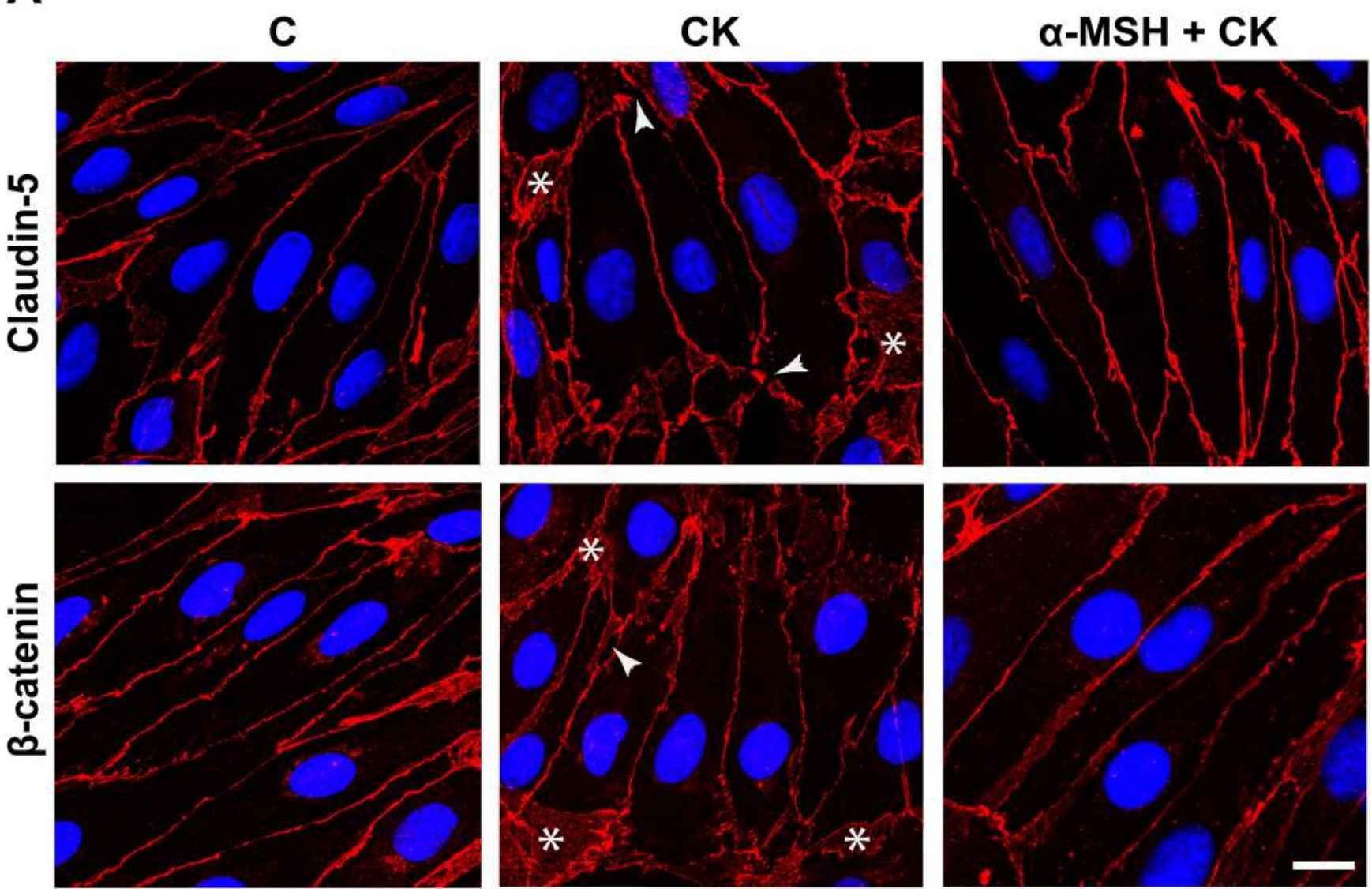

B

\section{Claudin-5 immunhistochemistry}

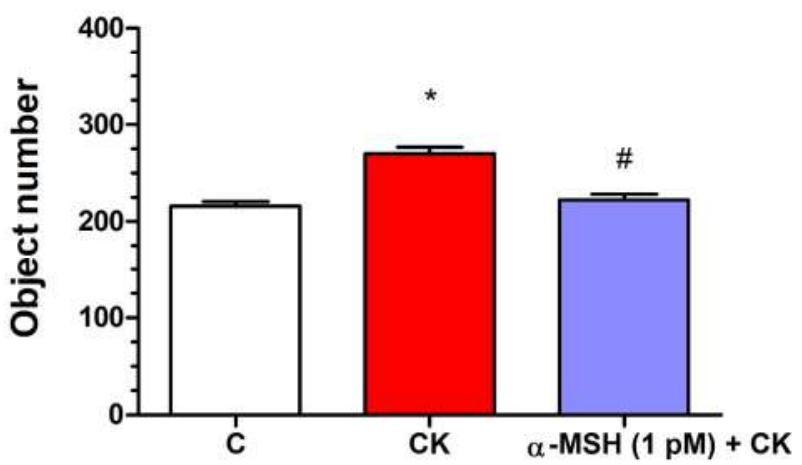

C

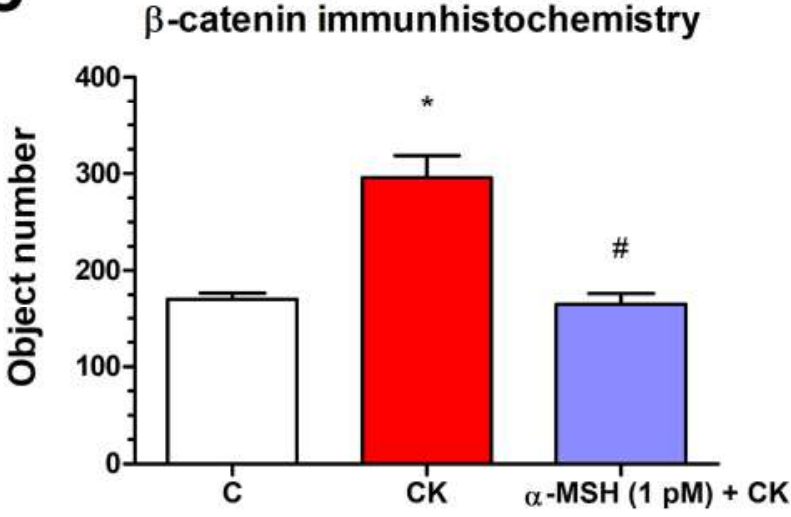

Figure 5 The effect of $\alpha$-MSH treatment on the immunostaining of tight junction proteins claudin- 5 and $\beta$-catenin in cytokine treated rat brain endothelial cells. (A) Rat brain endothelial cells were treated with cytokines ( $10 \mathrm{ng} / \mathrm{ml} \mathrm{TNF}-\alpha$ and $10 \mathrm{ng} / \mathrm{ml} \mathrm{IL}-1 \beta)$ without or with $1 \mathrm{pM}$ $\alpha$-MSH for $1 \mathrm{~h}$ and stained for tight junction proteins claudin- 5 and $\beta$-catenin. The control group received culture medium. The fluorescent microscopy images demonstrate the expression and organization of the junctional proteins. Cytokine treatment significantly increased the number of gaps and intracellular redistribution compared to the control and $\alpha-\mathrm{MSH}$ treated group. Arrowheads: gaps and fragmented junctional staining; asterisks: cytoplasmic redistribution of junctional proteins. Scale bar: $10 \mu \mathrm{m}$. (B) The object number on the claudin-5 immunostained pictures was quantified by MATLAB software. (C) The object number on the $\beta$-catenin immunostained pictures was quantified by MATLAB software. Mean \pm SEM, $n=4,{ }^{*} P<0.05, \# P<0.05 .{ }^{*}$ : CK compared to C; \#: CK + MSH compared to CK. C, control group; CK, cytokine treated group; $\alpha-\mathrm{MSH}+\mathrm{CK}$, $\alpha-\mathrm{MSH}$, and cytokine treated group.

Full-size iص DOI: 10.7717 /peerj.4774/fig-5 


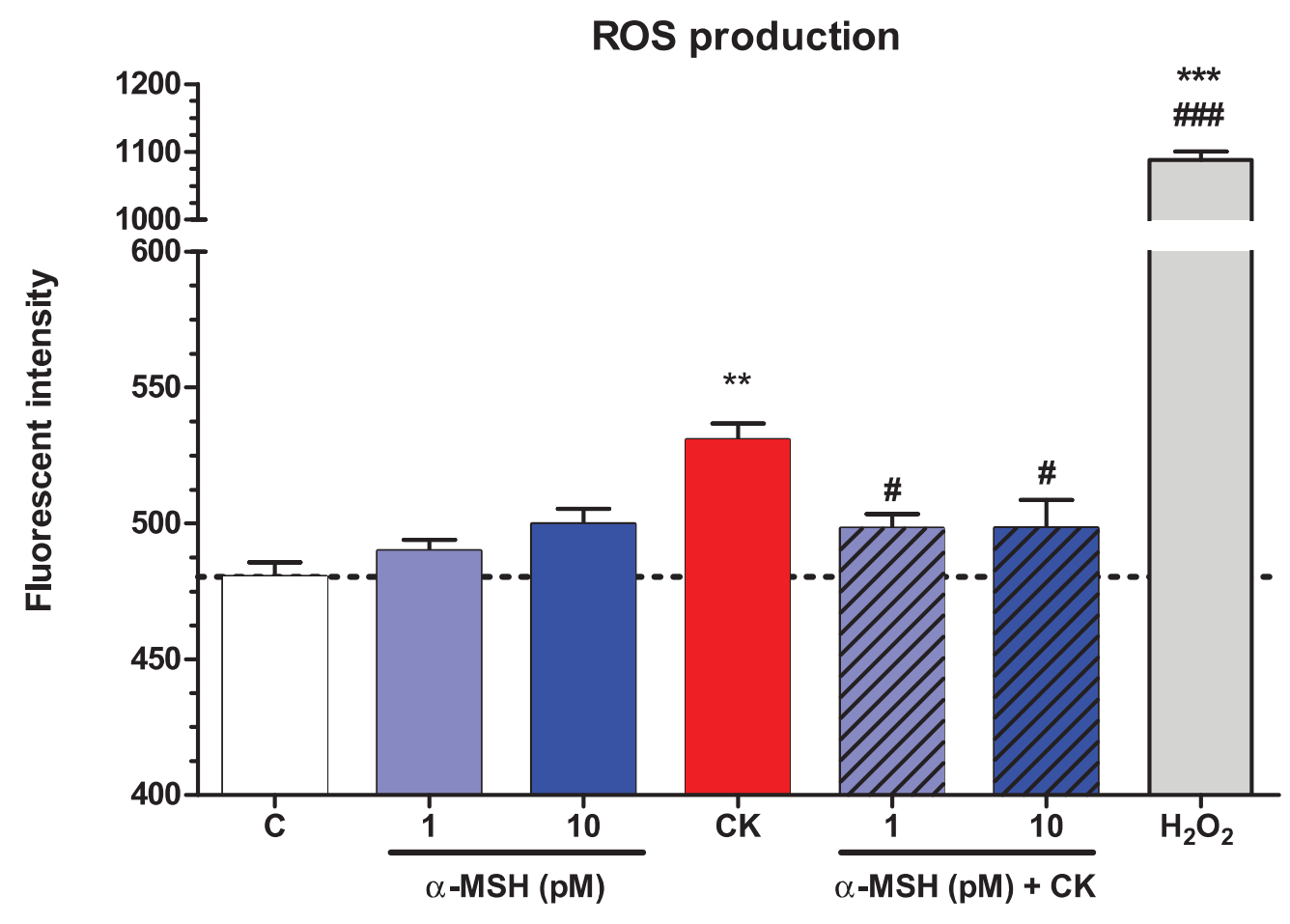

Figure 6 The effect of $\alpha$-MSH treatment on the reactive oxygen species production in cytokine treated rat brain endothelial cells. Rat brain endothelial cells were treated with cytokines $(10 \mathrm{ng} / \mathrm{ml}$ TNF- $\alpha$ and $10 \mathrm{ng} / \mathrm{ml}$ IL-1 $\beta$ ) without or with 1 or $10 \mathrm{pM} \alpha$-MSH for $1 \mathrm{~h}$. Cells were also treated with 1 or $10 \mathrm{pM} \alpha-\mathrm{MSH}$ alone. Control group received culture medium. Mean \pm SEM, $n=4-8$. C, control group; CK, cytokine treated group; $\mathrm{H}_{2} \mathrm{O}_{2}$, hydrogen peroxide treated group $(100 \mu \mathrm{M}) .{ }^{* *} P<0.01,{ }^{* * *} P<0.001$, ${ }^{\#} P<0.05,{ }^{\# \# \#} P<0.001$. Asterisks indicate that groups were compared to the control group. Pound signs indicate that groups were compared to the cytokine-treated group. C, control group; CK, cytokine treated group; $\alpha-\mathrm{MSH}+\mathrm{CK}, \alpha-\mathrm{MSH}$ and cytokine treated group.

Full-size

in rat brain endothelial cells (Fig. 7). This NF- $\mathrm{KB}$ nuclear translocation, which was also quantified based on the fluorescent intensity of the immunostainings, was inhibited by $\alpha$-MSH at $1 \mathrm{pM}$ concentration (Fig. 7A), and which was the most effective in other experiments.

\section{DISCUSSION}

The proper function of the BBB is crucial for CNS homeostasis and BBB dysfunction can be both the cause and consequence of neuronal injury (Stanimirovic \& Friedman, 2012; Zhao et al., 2015; Liebner et al., 2018). The neuroprotective effects of $\alpha$-MSH were already investigated in different in vivo experimental models (Catania, 2008), but there are no data related to the BBB. Based on our recent study, in which $\alpha-\mathrm{MSH}$ reduced cytokine-induced barrier dysfunction in human intestinal epithelial cells (Váradi et al., 2017), we hypothesized a protective effect of this neurohormone on brain endothelial cells. 
A
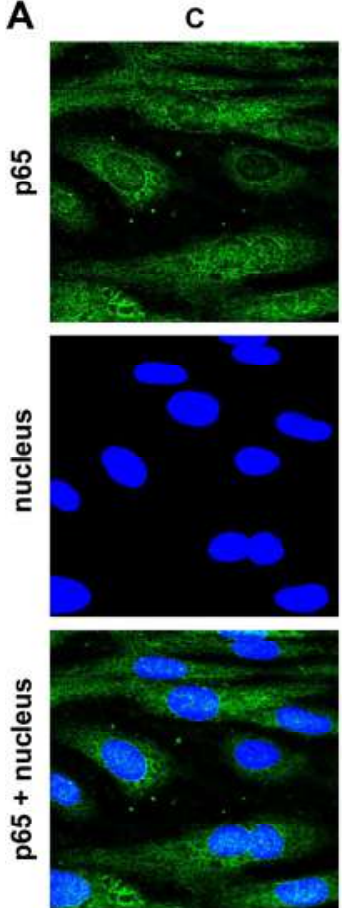
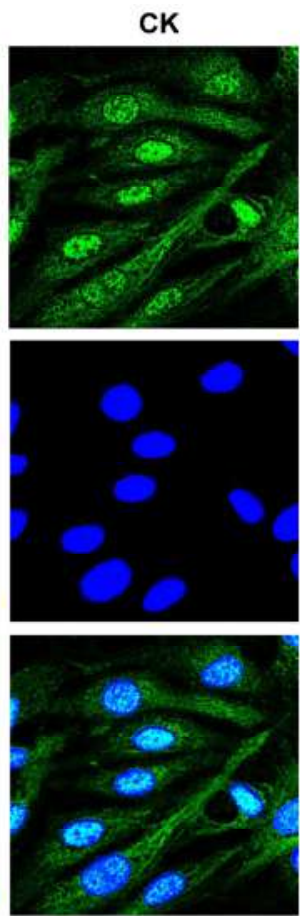

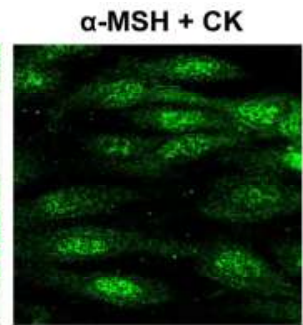

B
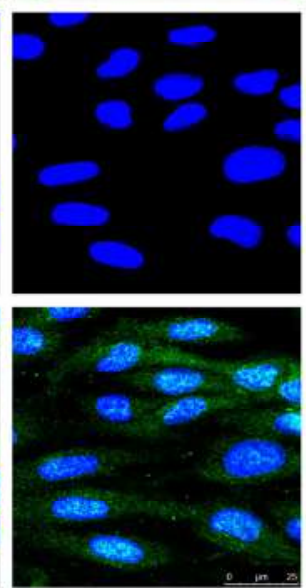

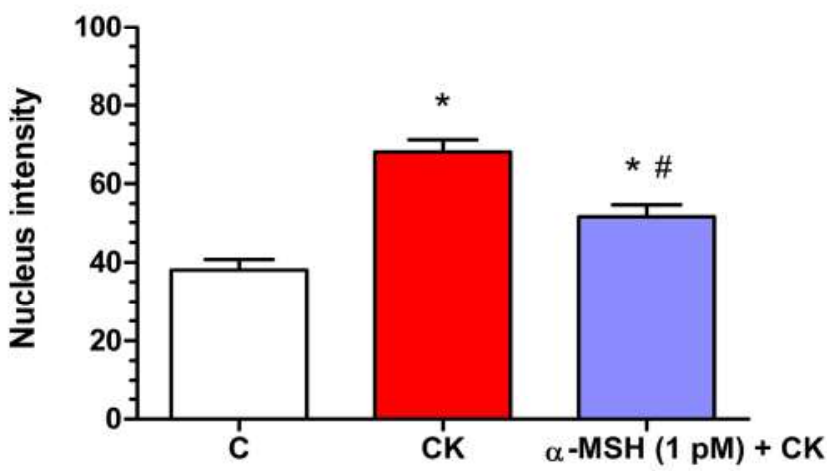

Figure 7 Immunohistochemical staining and analysis of NF- $\mathrm{KB}$ activation in cytokine- and $\alpha-\mathrm{MSH}$-treated brain endothelial cells. (A) Rat brain endothelial cells were treated with culture medium, cytokines (10 ng/ml TNF- $\alpha$ and $10 \mathrm{ng} / \mathrm{ml}$ IL-1 $\beta$ ), or cytokines and $1 \mathrm{pM} \alpha$-MSH. Nuclear localization of the NF- $\mathrm{KB}$ p65 subunit was monitored by immunostaining. Cell nuclei were labeled with Hoechst 33342 . Green: p65 staining; blue: cell nuclei. Scale bar: $25 \mu \mathrm{m}$. (B) Fluorescence intensity of the NF- $\kappa B$ immunostaining in cell nuclei and cytoplasm. Mean \pm SEM, $n=20-28$, ${ }^{*} \mathrm{P}<0.05,{ }^{\#} \mathrm{P}<0.05$. *: CK, CK + MSH compared to C; ${ }^{\#}: \mathrm{CK}+\mathrm{MSH}$ compared to CK. C, control group; CK, cytokine treated group; $\alpha-\mathrm{MSH}+\mathrm{CK}$, $\alpha$-MSH and cytokine treated group.

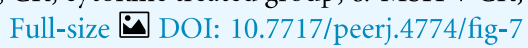

MC1R participates in the mediation of the anti-inflammatory action of $\alpha$-MSH in both the CNS and the periphery (Brzoska et al., 2008). We demonstrated for the first time the expression of $\mathrm{MC1R}$, the main receptor of $\alpha-\mathrm{MSH}$, on isolated rat brain microvessels and cultured brain endothelial cells both at the mRNA and protein level (Fig. 1). MC1R is expressed not only in the CNS but also in peripheral tissues (Brzoska et al., 2008), including human intestinal epithelial cells (Váradi et al., 2017). Our findings are in agreement with the presence of $\alpha-\mathrm{MSH}$ binding sites on cultured mouse brain endothelial cells (de Angelis et al., 1995).

We tested the effect of $\alpha-\mathrm{MSH}$ on rat brain endothelial cells in a wide range of concentrations, from $1 \mathrm{pM}$ to $1 \mu \mathrm{M}$, and found no change in the cell kinetics indicating undisturbed cell function and monolayer integrity (Fig. 2). The physiological concentration of $\alpha-\mathrm{MSH}$ is low in both human plasma (6 pM; Magnoni et al., 2003) and newborn pig plasma samples (30 pM; Kovács et al., 2001). The level of $\alpha$-MSH changes in pathological conditions: in our previous study asphyxia and reperfusion increased the level of $\alpha-\mathrm{MSH}$ in the plasma, but decreased it in the cerebrospinal fluid of newborn pigs (Kovács et al., 2001). The neuropeptide in the blood is secreted from the pituitary, while $\alpha-\mathrm{MSH}$ in the cerebrospinal fluid is derived from the CNS, explaining the 
discordant regulation of the neuropeptide in these two compartments (de Rotte, Bouman \& van Wimersma Greidanus, 1980). A low permeability for intravenously injected $\alpha-\mathrm{MSH}$ was measured across the BBB in rats (Wilson, 1988), indicating the absence of an active transport. At pathologically high or pharmacological concentrations $\alpha$-MSH crosses the BBB contributing to the brain levels (de Rotte, Bouman \& van Wimersma Greidanus, 1980; Banks \& Kastin, 1995).

To mimic inflammatory conditions, a combination of TNF- $\alpha$ and IL- $1 \beta$ was selected to induce barrier dysfunction on the BBB model, similarly to our previous study on cultured intestinal epithelial cells (Váradi et al., 2017). Brain endothelial cells were more sensitive to cytokine treatment, lower concentrations were already effective to induce enhanced permeability as compared to epithelial cells (Váradi et al., 2017). Proinflammatory cytokines are linked to increased permeability in brain endothelial cell cultures (Deli et al., 1995; Didier et al., 2003; Lopez-Ramirez et al., 2012). As expected, TNF- $\alpha$ and IL-1 $\beta$ decreased the impedance of the cell layers (Fig. 3 ) and elevated the permeability for marker molecules dextran and albumin on the BBB model (Fig. 4), indicating a barrier leakage, which was inhibited by $\alpha-\mathrm{MSH}$. The same barrier protective effect was found on intestinal epithelial cells, too (Váradi et al., 2017). Treatment with $\alpha-\mathrm{MSH}$ in physiological concentrations did not modify the basal permeability of the BBB model. Previous studies in rats also found that $\alpha-\mathrm{MSH}$ at low concentrations did not alter BBB permeability for albumin (Sankar, Domer \& Kastin, 1981) or a small anion (Kastin \& Fabre, 1982).

The cytokine-induced disruption of rat brain endothelial cell layers was also reflected at the level of cell-cell interactions. In concordance with the functional measurements of barrier opening, cytokine treatment caused a discontinuous immunostaining at cellular borders, and cytoplasmic redistribution for claudin- 5 and $\beta$-catenin (Fig. 5). The fragmented staining at the intercellular junctions and the increased presence of the junctional proteins in the cytoplasm of brain endothelial cells were reflected by the elevated object number on the immunostained culture samples. In our recent work we also demonstrated morphological changes at cellular junctions in parallel with opening of the barrier by TJ modulator peptides in a BBB model (Bocsik et al., 2016). Elevated TNF- $\alpha$ and IL- $1 \beta$ expression, disruption of TJ proteins and increased BBB permeability were also found in mice treated with an environmental toxicant and nanoparticles (Zhang et al., 2012). The direct link between these events was proven in two independent works. NF- $\mathrm{\kappa B}$ response elements were identified in the promoter region of claudin-5 gene, and TNF- $\alpha$ treatment significantly reduced the promoter activity and the transcription of claudin-5 in both brain and myocardial endothelial cells (Burek \& Förster, 2009). TNF- $\alpha$ treatment repressed claudin- 5 promoter activity in mouse brain endothelial cell cultures via NF- $\kappa B$ signaling and $\mathrm{p} 65$ overexpression (Aslam et al., 2012). In addition to claudin-5, the decrease of MARVELD-2, another TJ protein was also induced by pro-inflammatory cytokine treatment in human brain endothelial cells (Lopez-Ramirez et al., 2013).

Oxidative stress is one of the main mechanisms of neuronal toxicity in inflammation (Sochocka, Diniz \& Leszek, 2017). ROS are also central in increased BBB permeability 
induced by cytokines (Rochfort \& Cummins, 2015), or by amyloid- $\beta$ peptide (Veszelka et al., 2013). We also measured elevated ROS production after cytokine treatment in brain endothelial cells, which was inhibited by $\alpha-\mathrm{MSH}$ (Fig. 6). While no data are available on BBB models, suppression of ROS production and oxidative stress as an important element of the anti-inflammatory effect of $\alpha-\mathrm{MSH}$ were demonstrated on other cell types (Brzoska et al., 2008).

Translocation of the NF- $\kappa B$ p 65 subunit into cell nuclei is a key event in inflammatory reactions in the CNS (Catania, 2008). The canonical NF- $\kappa B$ pathway can be induced by both TNF- $\alpha$ and IL- $1 \beta$ and lead to the transcription of genes, like cyclooxigenase-2, nitric oxide synthase, inflammatory cytokines, and matrix metalloproteinases (Pires et al., 2018), which participate in BBB dysfunction and opening (Rosenberg, 2012). The nuclear translocation of NF- $\mathrm{\kappa B}$ was described in peripheral endothelial cells induced by TNF- $\alpha$ or IL-1 $\beta$ (Makó et al., 2010), as well as in brain endothelial cell inflammatory pathway (Lee et al., 2001). We confirmed in our study that cytokine treatment induced NF- $\kappa B$ nuclear translocation in brain endothelial cells, and proved that $\alpha-\mathrm{MSH}$ can inhibit this effect (Fig. 7), similarly to our recent findings on epithelial cells (Váradi et al., 2017). Since NF- $\kappa B$ signaling in TNF- $\alpha$ treated brain endothelial cells can directly decrease claudin-5 expression (Burek \& Förster, 2009; Aslam et al., 2012), this signaling pathway can mediate, at least partially, the protective effect of $\alpha-\mathrm{MSH}$ on barrier integrity. Our data are supported by another study where $\alpha-\mathrm{MSH}$ blocked adhesion molecule expression by NF- $\mathrm{\kappa B}$ inhibition in cytokine treated human dermal microvascular endothelial cells (Kalden et al., 1999). These results further strengthen the role of $\alpha$-MSH as a potent anti-inflammatory molecule which exerts its effect by inhibition of the NF- $\kappa \mathrm{B}$ transcription factor.

In conclusion, the direct protective effect of $\alpha$-MSH on pro-inflammatory cytokineinduced barrier dysfunction and inflammatory activation in rat brain endothelial cell cultures was investigated for the first time in this study. We demonstrated the presence of the major $\alpha-\mathrm{MSH}$ receptor MC1R on brain endothelial cells, and a protective effect of the anti-inflammatory hormone on cytokine-induced barrier opening in parallel with the inhibition of NF- $\mathrm{\kappa B}$ nuclear translocation in a BBB model. These findings support the beneficial effect of $\alpha-\mathrm{MSH}$ to restore BBB integrity in inflammatory conditions.

\section{ADDITIONAL INFORMATION AND DECLARATIONS}

\section{Funding}

The work was supported by grants EFOP-3.6.1-16-2016-00022, GINOP-2.2.1-15-201600007, GINOP-2.3.2-15-2016-00043 from the National Research, Development and Innovation Office, and co-financed by the European Union and the Regional Development and Social Funds. The funders had no role in study design, data collection and analysis, decision to publish, or preparation of the manuscript. 


\section{Grant Disclosures}

The following grant information was disclosed by the authors:

National Research, Development and Innovation Office: EFOP-3.6.1-16-2016-00022,

GINOP-2.2.1-15-2016-00007, GINOP-2.3.2-15-2016-00043.

European Union and the Regional Development and Social Fund.

\section{Competing Interests}

Maria A. Deli is an Academic Editor for PeerJ. Vilmos Tubak is employed by Creative Laboratory Ltd.

\section{Author Contributions}

- András Harazin conceived and designed the experiments, performed the experiments, analyzed the data, prepared figures and/or tables, authored or reviewed drafts of the paper, approved the final draft.

- Alexandra Bocsik conceived and designed the experiments, performed the experiments, analyzed the data, prepared figures and/or tables, authored or reviewed drafts of the paper, approved the final draft.

- Lilla Barna performed the experiments, analyzed the data, prepared figures and/or tables, approved the final draft.

- András Kincses performed the experiments, analyzed the data, prepared figures and/or tables, approved the final draft.

- Judit Váradi conceived and designed the experiments, contributed reagents/materials/ analysis tools, authored or reviewed drafts of the paper, approved the final draft.

- Ferenc Fenyvesi conceived and designed the experiments, contributed reagents/materials/ analysis tools, authored or reviewed drafts of the paper, approved the final draft.

- Vilmos Tubak analyzed the data, contributed reagents/materials/analysis tools, authored or reviewed drafts of the paper, approved the final draft.

- Maria A. Deli conceived and designed the experiments, analyzed the data, contributed reagents/materials/analysis tools, authored or reviewed drafts of the paper, approved the final draft.

- Miklós Vecsernyés conceived and designed the experiments, contributed reagents/ materials/analysis tools, authored or reviewed drafts of the paper, approved the final draft.

\section{Data Availability}

The following information was supplied regarding data availability:

The raw data are provided as a Supplemental File.

\section{Supplemental Information}

Supplemental information for this article can be found online at http://dx.doi.org/ 10.7717/peerj.4774\#supplemental-information.

\section{REFERENCES}

Ábrahám CS, Deli MA, Joó F, Megyeri P, Torpier G. 1996. Intracarotid tumor necrosis factor- $\alpha$ administration increases the blood-brain barrier permeability in cerebral cortex of the newborn 
pig: quantitative aspects of double-labelling studies and confocal laser scanning analysis. Neuroscience Letters 208(2):85-88 DOI 10.1016/0304-3940(96)12546-5.

Aslam M, Ahmad N, Srivastava R, Hemmer B. 2012. TNF- $\alpha$ induced NFKB signaling and p65 (RelA) overexpression repress Cldn5 promoter in mouse brain endothelial cells. Cytokine 57(2):269-275 DOI 10.1016/j.cyto.2011.10.016.

Banks WA, Kastin AJ. 1995. Permeability of the blood-brain barrier to melanocortins. Peptides 16(6):1157-1161 DOI 10.1016/0196-9781(95)00043-j.

Bocsik A, Walter FR, Gyebrovszki A, Fülöp L, Blasig I, Dabrowski S, Ötvös F, Tóth A, Rákhely G, Veszelka S, Vastag M, Szabó-Révész P, Deli MA. 2016. Reversible opening of intercellular junctions of intestinal epithelial and brain endothelial cells with tight junction modulator peptides. Journal of Pharmaceutical Sciences 105(2):754-765 DOI 10.1016/j.xphs.2015.11.018.

Brzoska T, Luger TA, Maaser C, Abels C, Böhm M. 2008. $\alpha$-Melanocyte-stimulating hormone and related tripeptides: biochemistry, antiinflammatory and protective effects in vitro and in vivo, and future perspectives for the treatment of immune-mediated inflammatory diseases. Endocrine Reviews 29(5):581-602 DOI 10.1210/er.2007-0027.

Burek M, Förster CY. 2009. Cloning and characterization of the murine claudin-5 promoter. Molecular and Cellular Endocrinology 298(1-2):19-24 DOI 10.1016/j.mce.2008.09.041.

Catania A. 2008. Neuroprotective actions of melanocortins: a therapeutic opportunity. Trends in Neurosciences 31(7):353-360 DOI 10.1016/j.tins.2008.04.002.

Catania A, Lonati C, Sordi A, Carlin A, Leonardi P, Gatti S. 2010. The melanocortin system in control of inflammation. Scientific World Journal 10:1840-1853 DOI 10.1100/tsw.2010.173.

De Angelis E, Sahm UG, Ahmed AR, Olivier GW, Notarianni LJ, Branch SK, Moss SH, Pouton CW. 1995. Identification of a melanocortin receptor expressed by murine brain microvascular endothelial cells in culture. Microvascular Research 50(1):25-34 DOI 10.1006/mvre.1995.1035.

De Rotte AA, Bouman HJ, Van Wimersma Greidanus TB. 1980. Relationships between $\alpha-\mathrm{MSH}$ levels in blood and in cerebrospinal fluid. Brain Research Bulletin 5(4):375-381 DOI 10.1016/s0361-9230(80)80007-4.

Deli MA, Abrahám CS, Kataoka Y, Niwa M. 2005. Permeability studies on in vitro blood-brain barrier models: physiology, pathology, and pharmacology. Cellular and Molecular Neurobiology 25(1):59-127 DOI 10.1007/s10571-004-1377-8.

Deli MA, Descamps L, Dehouck MP, Cecchelli R, Joó F, Ábrahám CS, Torpier G. 1995. Exposure of tumor necrosis factor- $\alpha$ to luminal membrane of bovine brain capillary endothelial cells cocultured with astrocytes induces a delayed increase of permeability and cytoplasmic stress fiber formation of actin. Journal of Neuroscience Research 41(6):717-726

DOI 10.1002/jnr.490410602.

Didier N, Romero IA, Créminon C, Wijkhuisen A, Grassi J, Mabondzo A. 2003. Secretion of interleukin-1beta by astrocytes mediates endothelin- 1 and tumour necrosis factor- $\alpha$ effects on human brain microvascular endothelial cell permeability. Journal of Neurochemistry 86(1):246-254 DOI 10.1046/j.1471-4159.2003.01829.x.

Erickson MA, Banks WA. 2018. Neuroimmune axes of the blood-brain barriers and blood-brain interfaces: bases for physiological regulation, disease states, and pharmacological interventions. Pharmacological Reviews 70(2):278-314 DOI 10.1124/pr.117.014647.

Forslin Aronsson A, Spulber S, Oprica M, Winblad B, Post C, Schultzberg M. 2007. $\alpha-\mathrm{MSH}$ rescues neurons from excitotoxic cell death. Journal of Molecular Neuroscience 33(3):239-251 DOI 10.1007/s12031-007-0019-2. 
Hoogland IC, Houbolt C, van Westerloo DJ, Van Gool WA, Van de Beek D. 2015. Systemic inflammation and microglial activation: systematic review of animal experiments. Journal of Neuroinflammation 12(1):114 DOI 10.1186/s12974-015-0332-6.

Huang Q, Tatro JB. 2002. $\alpha$-Melanocyte stimulating hormone suppresses intracerebral tumor necrosis factor- $\alpha$ and interleukin- $1 \beta$ gene expression following transient cerebral ischemia in mice. Neuroscience Letters 334(3):186-190 DOI 10.1016/s0304-3940(02)01088-1.

Kalden DH, Scholzen T, Brzoska T, Luger TA. 1999. Mechanisms of the antiinflammatory effects of $\alpha$-MSH. Role of transcription factor NF- $\mathrm{KB}$ and adhesion molecule expression. Annals of the New York Academy of Sciences 885(1):254-261 DOI 10.1111/j.1749-6632.1999.tb08682.x.

Kastin AJ, Fabre LA. 1982. Limitations to effect of $\alpha-\mathrm{MSH}$ on permeability of blood-brain barrier to IV 99mTc-pertechnetate. Pharmacology Biochemistry and Behavior 17(6):1199-1201 DOI 10.1016/0091-3057(82)90120-4.

Kiss L, Hellinger É, Pilbat AM, Kittel Á, Török Z, Füredi A, Szakács G, Veszelka S, Sipos P, Ózsvári B, Puskás LG, Vastag M, Szabó-Révész P, Deli MA. 2014. Sucrose esters increase drug penetration, but do not inhibit P-glycoprotein in Caco-2 intestinal epithelial cells. Journal of Pharmaceutical Sciences 103(10):3107-3119 DOI 10.1002/jps.24085.

Kovács J, Julesz J, Mogyoróssy MV, Deli MA, Ábrahám CS, Vecsernyés M. 2001. Asphyxiainduced release of $\alpha$-melanocyte-stimulating hormone in newborn pigs. Peptides 22(7):1049-1053 DOI 10.1016/s0196-9781(01)00440-5.

Lee YW, Hennig B, Fiala M, Kim KS, Toborek M. 2001. Cocaine activates redox-regulated transcription factors and induces TNF- $\alpha$ expression in human brain endothelial cells. Brain Research 920(1-2):125-133 DOI 10.1016/s0006-8993(01)03047-5.

Lénárt N, Walter FR, Bocsik A, Sántha P, Tóth ME, Harazin A, Tóth AE, Vizler C, Török Z, Pilbat AM, Vígh L, Puskás LG, Sántha M, Deli MA. 2015. Cultured cells of the blood-brain barrier from apolipoprotein B-100 transgenic mice: effects of oxidized low-density lipoprotein treatment. Fluids and Barriers of the CNS 12(1):17 DOI 10.1186/s12987-015-0013-y.

Liebner S, Dijkhuizen RM, Reiss Y, Plate KH, Agalliu D, Constantin G. 2018. Functional morphology of the blood-brain barrier in health and disease. Acta Neuropathologica 135(3):311-336 DOI 10.1007/s00401-018-1815-1.

Lopez-Ramirez MA, Fischer R, Torres-Badillo CC, Davies HA, Logan K, Pfizenmaier K, Male DK, Sharrack B, Romero IA. 2012. Role of caspases in cytokine-induced barrier breakdown in human brain endothelial cells. Journal of Immunology 189(6):3130-3139 DOI 10.4049/jimmunol.1103460.

Lopez-Ramirez MA, Male DK, Wang C, Sharrack B, Wu D, Romero IA. 2013. Cytokine-induced changes in the gene expression profile of a human cerebral microvascular endothelial cell-line, hCMEC/D3. Fluids and Barriers of the CNS 10(1):27 DOI 10.1186/2045-8118-10-27.

Magnoni S, Stocchetti N, Colombo G, Carlin A, Colombo A, Lipton JM, Catania A. 2003. $\alpha$-Melanocyte-stimulating hormone is decreased in plasma of patients with acute brain injury. Journal of Neurotrauma 20(3):251-260 DOI 10.1089/089771503321532833.

Makó V, Czúcz J, Weiszhár Z, Herczenik E, Matkó J, Prohászka Z, Cervenak L. 2010. Proinflammatory activation pattern of human umbilical vein endothelial cells induced by IL-1 $\beta$, TNF- $\alpha$, and LPS. Cytometry Part A 77A(10):962-970 DOI 10.1002/cyto.a.20952.

Megyeri P, Abrahám CS, Temesvári P, Kovács J, Vas T, Speer CP. 1992. Recombinant human tumor necrosis factor $\alpha$ constricts pial arterioles and increases blood-brain barrier permeability in newborn piglets. Neuroscience Letters 148(1-2):137-140 DOI 10.1016/0304-3940(92)90823-p. 
Nakagawa S, Deli MA, Kawaguchi H, Shimizudani T, Shimono T, Kittel A, Tanaka K, Niwa M. 2009. A new blood-brain barrier model using primary rat brain endothelial cells, pericytes and astrocytes. Neurochemistry International 54(3-4):253-263 DOI 10.1016/j.neuint.2008.12.002.

Perrière N, Demeuse P, Garcia E, Regina A, Debray M, Andreux JP, Couvreur P, Scherrmann JM, Temsamani J, Couraud PO, Deli MA, Roux F. 2005. Puromycin-based purification of rat brain capillary endothelial cell cultures. Effect on the expression of blood-brain barrier-specific properties. Journal of Neurochemistry 93(2):279-289 DOI 10.1111/j.1471-4159.2004.03020.x.

Pires BRB, Silva RCMC, Ferreira GM, Abdelhay E. 2018. NF-kappaB: two sides of the same coin. Genes 9(1):24 DOI 10.3390/genes9010024.

Rajora N, Boccoli G, Catania A, Lipton JM. 1997a. $\alpha-\mathrm{MSH}$ modulates experimental inflammatory bowel disease. Peptides 18(3):381-385 DOI 10.1016/s0196-9781(96)00345-2.

Rajora N, Boccoli G, Burns D, Sharma S, Catania AP, Lipton JM. 1997b. $\alpha$-MSH modulates local and circulating tumor necrosis factor- $\alpha$ in experimental brain inflammation. Journal of Neuroscience 17(6):2181-2186 DOI 10.1523/jneurosci.17-06-02181.1997.

Rochfort KD, Cummins PM. 2015. The blood-brain barrier endothelium: a target for proinflammatory cytokines. Biochemical Society Transactions 43(4):702-706 DOI 10.1042/BST20140319.

Rosenberg GA. 2012. Neurological diseases in relation to the blood-brain barrier. Journal of Cerebral Blood Flow \& Metabolism 32(7):1139-1151 DOI 10.1038/jcbfm.2011.197.

Sankar R, Domer FR, Kastin AJ. 1981. Selective effects of $\alpha$-MSH and MIF-1 on the blood-brain barrier. Peptides 2(3):345-347 DOI 10.1016/s0196-9781(81)80127-1.

Sántha P, Veszelka S, Hoyk Z, Mészáros M, Walter FR, Tóth AE, Kiss L, Kincses A, Oláh Z, Seprényi G, Rákhely G, Dér A, Pákáski M, Kálmán J, Kittel Á, Deli MA. 2016. Restraint stressinduced morphological changes at the blood-brain barrier in adult rats. Frontiers in Molecular Neuroscience 8:88 DOI 10.3389/fnmol.2015.00088.

Sochocka M, Diniz BS, Leszek J. 2017. Inflammatory response in the CNS: friend or foe? Molecular Neurobiology 54(10):8071-8089 DOI 10.1007/s12035-016-0297-1.

Stanimirovic DB, Friedman A. 2012. Pathophysiology of the neurovascular unit: disease cause or consequence? Journal of Cerebral Blood Flow \& Metabolism 32(7):1207-1221 DOI 10.1038/jcbfm.2012.25.

Váradi J, Harazin A, Fenyvesi F, Réti-Nagy K, Gogolák P, Vámosi G, Bácskay I, Fehér P, Újhelyi Z, Vasvári G, Róka E, Haines D, Deli MA, Vecsernyés M. 2017. Alpha-melanocyte stimulating hormone protects against cytokine-induced barrier damage in Caco-2 intestinal epithelial monolayers. PLOS ONE 12(1):e0170537 DOI 10.1371/journal.pone.0170537.

Varga B, Gesztelyi R, Bombicz M, Haines D, Szabó AM, Kemény-Beke A, Antal M, Vecsernyés M, Juhász B, Tósaki A. 2013. Protective effect of alpha-melanocyte-stimulating hormone $(\alpha-\mathrm{MSH})$ on the recovery of ischemia/reperfusion (I/R)-induced retinal damage in a rat model. Journal of Molecular Neuroscience 50(3):558-570 DOI 10.1007/s12031-013-9998-3.

Vecsernyés M, Juhász B, Dér P, Kocsan R, Feher P, Bacskay I, Kovács P, Tósaki Á. 2003. The administration of $\alpha$-melanocyte-stimulating hormone protects the ischemic/reperfused myocardium. European Journal of Pharmacology 470(3):177-183

DOI 10.1016/s0014-2999(03)01780-1.

Vecsernyés M, Szokol M, Bombicz M, Priksz D, Gesztelyi R, Fülöp GA, Varga B, Juhász B, Haines D, Tósaki Á. 2017. Alpha-melanocyte-stimulating hormone induces vasodilation and exerts cardioprotection through the heme-oxygenase pathway in rat hearts. Journal of Cardiovascular Pharmacology 69(5):286-297 DOI 10.1097/FJC.0000000000000472. 
Veszelka S, Pásztói M, Farkas AE, Krizbai I, Ngo TK, Niwa M, Abrahám CS, Deli MA. 2007. Pentosan polysulfate protects brain endothelial cells against bacterial lipopolysaccharideinduced damages. Neurochemistry International 50(1):219-228

DOI 10.1016/j.neuint.2006.08.006.

Veszelka S, Tóth AE, Walter FR, Datki Z, Mózes E, Fülöp L, Bozsó Z, Hellinger E, Vastag M, Orsolits B, Környei Z, Penke B, Deli MA. 2013. Docosahexaenoic acid reduces amyloid- $\beta$ induced toxicity in cells of the neurovascular unit. Journal of Alzheimer's Disease 36:487-501 DOI 10.3233/JAD-120163.

Walter FR, Veszelka S, Pásztói M, Péterfi ZA, Tóth A, Rákhely G, Cervenak L, Ábrahám CS, Deli MA. 2015. Tesmilifene modifies brain endothelial functions and opens the blood-brain/ blood-glioma barrier. Journal of Neurochemistry 134(6):1040-1054 DOI 10.1111/jnc.13207.

Wilson JF. 1988. Low permeability of the blood-brain barrier to nanomolar concentrations of immunoreactive alpha-melanotropin. Psychopharmacology 96(2):262-266 DOI 10.1007/bf00177572.

Zhang B, Chen L, Choi JJ, Hennig B, Toborek M. 2012. Cerebrovascular toxicity of PCB153 is enhanced by binding to silica nanoparticles. Journal of Neuroimmune Pharmacology 7(4):991-1001 DOI 10.1007/s11481-012-9403-y.

Zhao Z, Nelson AR, Betsholtz C, Zlokovic BV. 2015. Establishment and dysfunction of the blood-brain barrier. Cell 163(5):1064-1078 DOI 10.1016/j.cell.2015.10.067. 